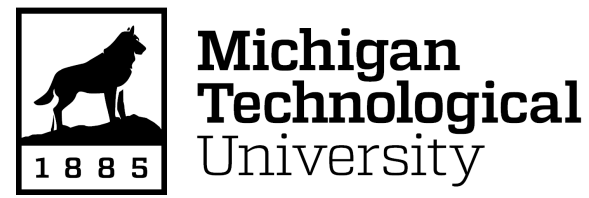

Michigan Technological University Digital Commons @ Michigan Tech

\title{
CONTRIBUTIONS OF GLACIER MELTING TO THE UPPER WATERSHED OF THE PITA RIVER, ECUADOR
}

Teresa Munoz Martinez

Michigan Technological University, tmunoz@mtu.edu

Copyright 2016 Teresa Munoz Martinez

\section{Recommended Citation}

Munoz Martinez, Teresa, "CONTRIBUTIONS OF GLACIER MELTING TO THE UPPER WATERSHED OF THE PITA RIVER, ECUADOR", Open Access Master's Report, Michigan Technological University, 2016.

https://doi.org/10.37099/mtu.dc.etdr/196

Follow this and additional works at: https://digitalcommons.mtu.edu/etdr

Part of the Environmental Studies Commons 


\title{
CONTRIBUTIONS OF GLACIER MELTING TO THE UPPER WATERSHED OF THE PITA RIVER, ECUADOR
}

\author{
By \\ Teresa Muñoz Martinez

\begin{abstract}
A REPORT
Submitted in partial fulfillment of the requirements for the degree of Master in Science

In Geological Engineering
\end{abstract}

MICHIGAN TECHNOLOGICAL UNIVERSITY

2016

(C) 2016 Teresa Muñoz Martinez 
This report has been approved in partial fulfillment of the requirements for the Degree of MASTER OF SCIENCE in Geological Engineering

Department of Geological/Mining Engineering and Sciences

Report Advisor: Dr. John Gierke.

Committee Member: $\quad$ Dr. Ann Maclean.

Committee Member: $\quad$ Dr. Joseph Wagenbrenner.

Department Chair: $\quad$ Dr. John Gierke. 


\section{DEDICATION:}

This work is dedicated to Sofia, Miranda and Juan Sebastian. 


\section{Contents}

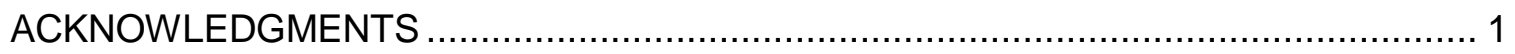

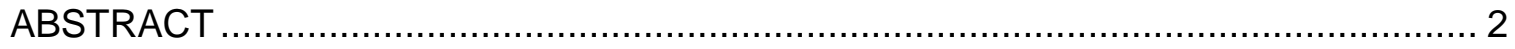

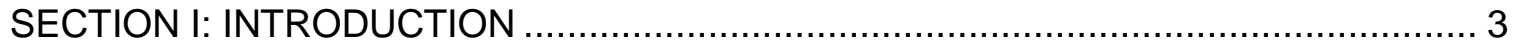

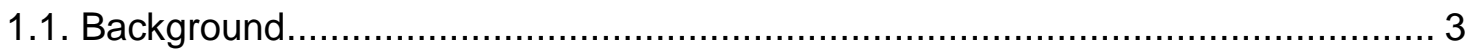

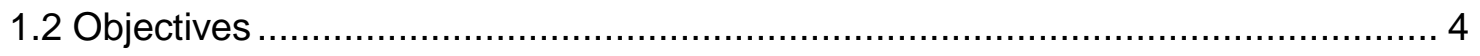

1.3. Physical description of the Upper Pita Watershed ............................................ 4

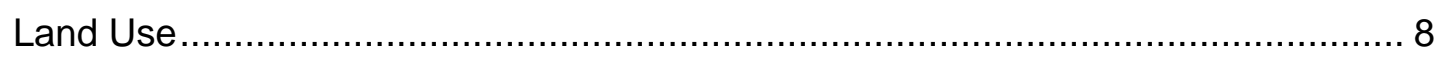

Geology

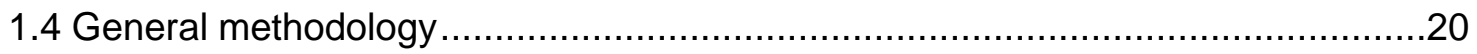

Geospatial data

Meteorological data

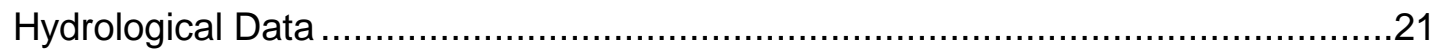

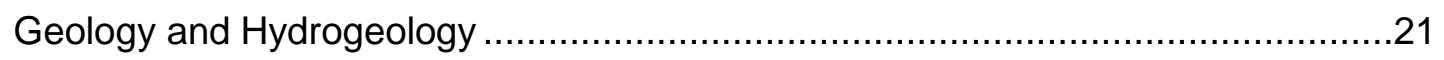

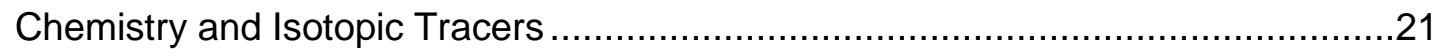

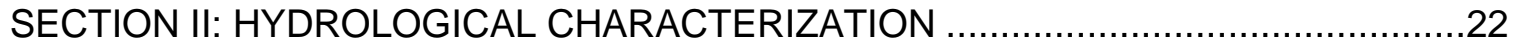

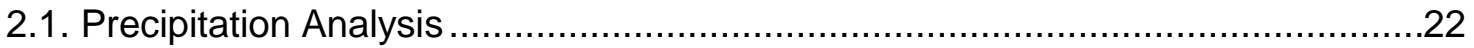

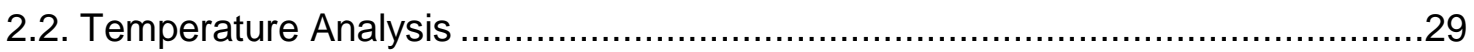

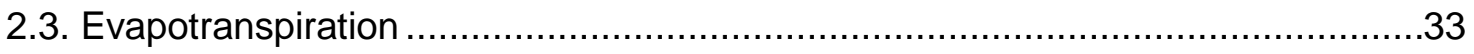

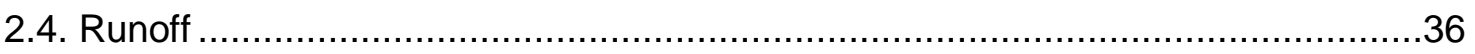

SECTION III WATER BUDGET AND SOURCES OF CONTRIBUTION .....................47

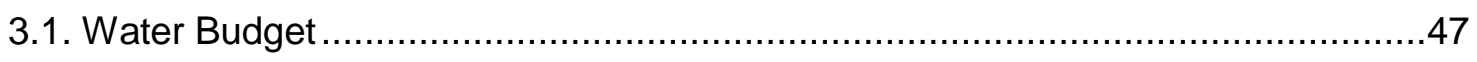

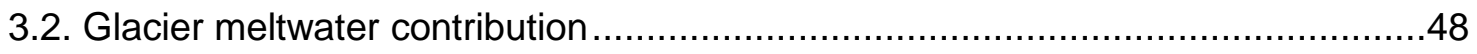

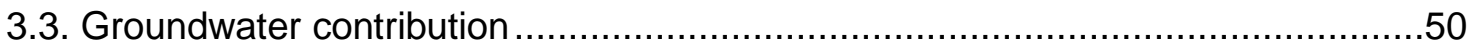

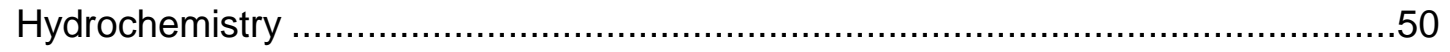

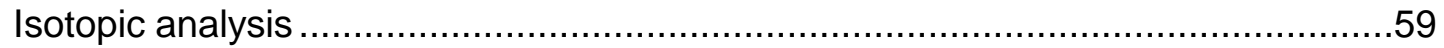

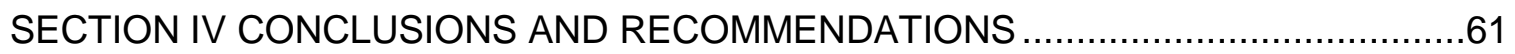

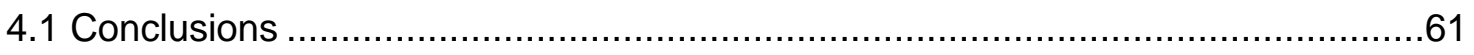

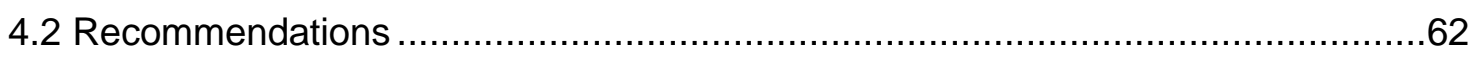

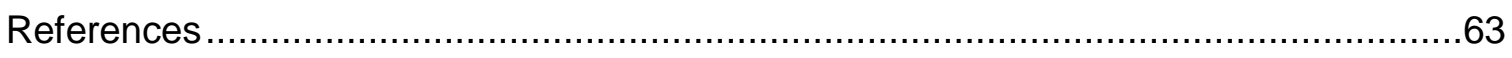




\section{LIST OF FIGURES}

Figure 1.1 Location Pita River Upper Watershed ............................................ 5

Figure 1.2 Pita watershed: Slope Map ........................................................... 6

Figure 1.3 Map of Contribution area from Cotopaxi and Sincholagua Volcanoes........... 7

Figure 1.4. Map of Land Usage in the Upper Pita River Watershed ..........................10

Figure 1.5. Stratigraphy of Cotopaxi Volcano Area (Pita watershed) .........................11

Figure 1.6 Geologic map of Cotopaxi Volcano - area upper Pita watershed. .................12

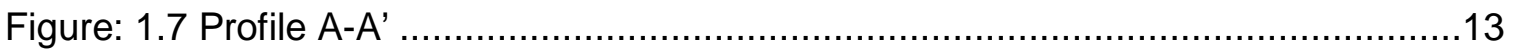

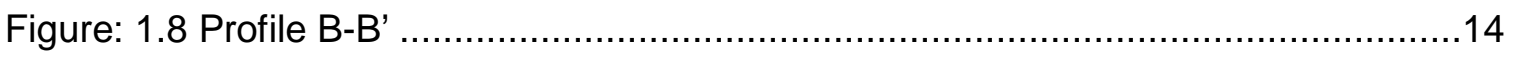

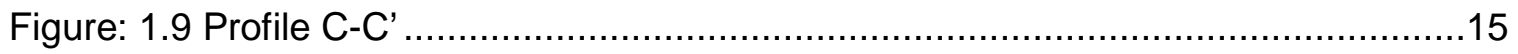

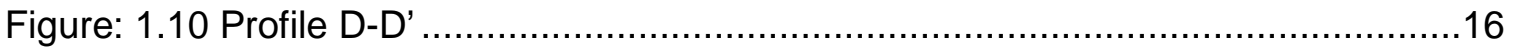

Figure 1.11. Permeability map in upper Pita watershed ........................................19

Figure 2.1 Location of the precipitation and hydrological stations in the study area .....24

Figure 2.2: Annual precipitation at Pita watershed ..............................................25

Figure 2.3 Isohyet map and hydrological stations in the study area ...........................26

Figure: 2.4 Bimodal patterns at Center-North part of the watershed .........................27

Figure 2.5 Modal pattern at eastern part of the watershed.....................................27

Figure 2.6 Relationship between total precipitation and elevation in 2011 across Pita

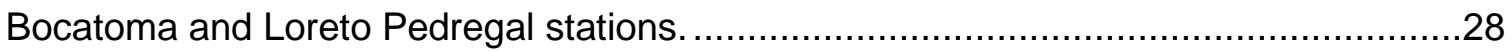

Figure 2.7. Upper Pita Watershed Hypsometric Function ....................................29

Figure 2.8: Monthly average temperature at Pita watershed ...................................30

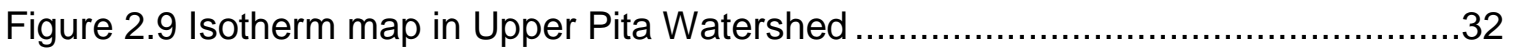

Figure 2.10: Precipitation, Discharge and Temperature at Pita Bocatoma ....................37

Figure 2.11: Discharge at Pita Bocatoma considering the wettest and driest years .......38

Figure 2.12 Accumulated discharge vs accumulated precipitation at Pita Bocatoma ....38

Figure 2.13: Discharge versus precipitation at Pita Bocatoma from 2008-2013 ............39

Figure 2.14 Contribution Areas for PT02 and PT03 ...........................................42

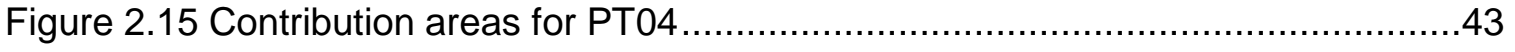

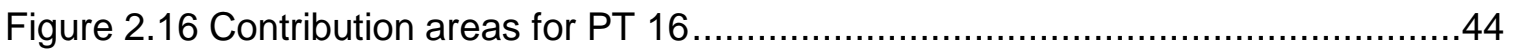

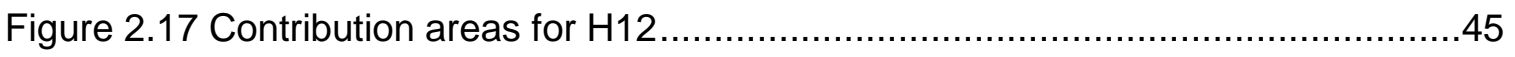

Figure 2.18. Average annual river discharge for Pita watershed................................46

Figure 3.1. Reduction of the glacier in Cotopaxi Volcano in upper Pita Watershed .......49

Figure 3.2 Location of the water samples in the study area ...................................53

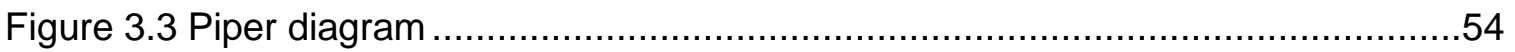

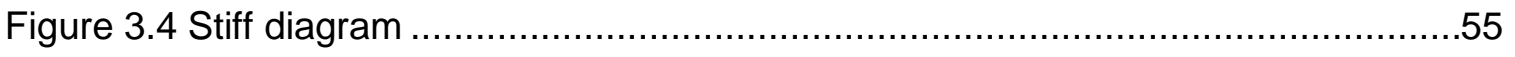

Figure 3.5. Water classification based on Piper Diagram....................................56

Figure 3.6. Chemical model using Schoeller-Berkaloff diagrams ..............................57

Figure 3.7: Stiff diagrams and isotopic fraction values at Upper Pita Watershed ..........58

Figure 3.9. Stable isotope distributions of oxygen-18 and deuterium .......................60 


\section{LIST OF TABLES}

Table 1.1 Mineralogy of the Cotopaxi volcano deposits ..........................................

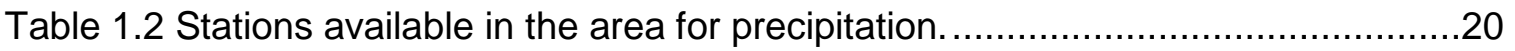

Table 1.3 Stations available in the area for temperature.......................................20

Table 1.3 Stations available in the area for discharge ...........................................21

Table 2.1 Location of the rain stations and Annual Precipitation in $\mathrm{mm}$.. .....................23

Table 2.2 Monthly precipitation at rain stations. Amounts presented in $\mathrm{mm}$...................25

Table 2.3 Precipitation averages using hypsometric method. ....................................29

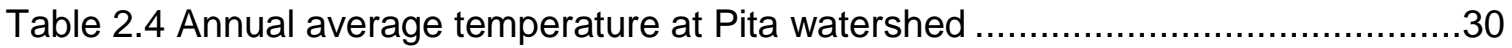

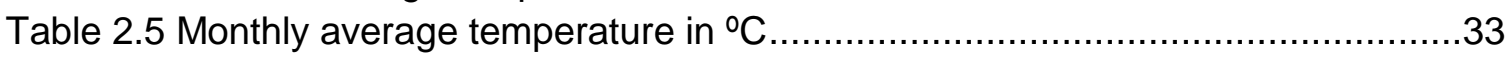

Table 2.6 PET using Thornthwaite general approach and Thornthwaite-Type Monthly

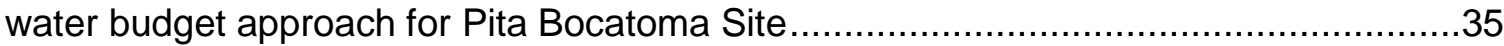

Table 2.7 PET using Thornthwaite general approach and Thornthwaite-Type Monthly

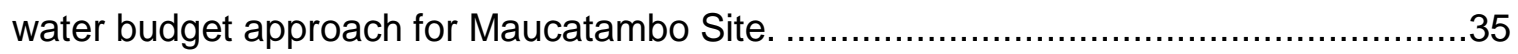

Table 2.8 Discharge monitoring stations for Pita System -EPMAPS ..........................36

Table 2.9 Monthly average of discharge $\left(\mathrm{m}^{3} / \mathrm{s}\right)$ in the Upper Pita Watershed .................36

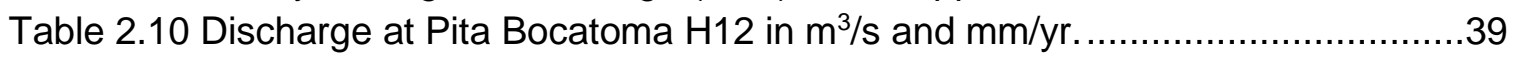

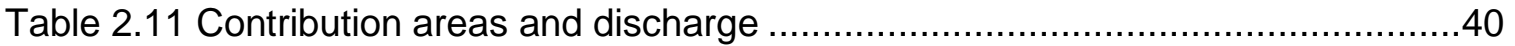

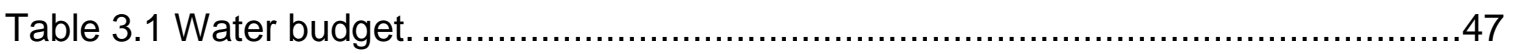

Table 3.2 Water budget considering runoff at Pita Bocatoma Station .........................48

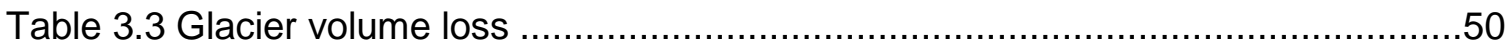

Table 3.4 Water sample location with description of the type of source .......................50

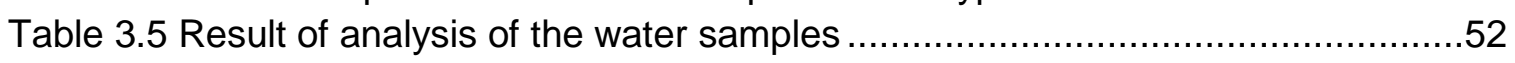

Table 3.6 Report of $\mathrm{rMg} / \mathrm{rCa}, \mathrm{rCl} / \mathrm{rHCO} 3 a n d \mathrm{rNa} / \mathrm{rCl}$ ratios calculations........................57

Table 3.7 Results of oxygen-18 and deuterium from water samples..........................59 


\section{ACKNOWLEDGMENTS}

First of all, I would like to thank Sofia, my lovely daughter, for accepting to be my companion, my friend, and my support and for being understanding when I needed to work on this.

I would like to thank John Gierke for encouraging me to come here and guiding me through all this time.

I would like to humbly thank Ms. Lina (Tormen) Taskovich for funding the Natale \& Maria Louisa Tormen Endowed Scholarship that I received.

I would also like to thank Empresa Pública Metropolitana de Agua Potable y Saneamiento de Quito (EPMAPS) for the support and data. Especially to Eng. Othon Zeballos, Lic. Juan Carlos Romero, Eng. Carlos Orellana and Eng. Homero Castanier. A particular thank to Cesar Vasconez for helping me gathering the data, his help and support I really appreciate.

More thanks go to my family for forgiving me for missing all the gatherings and let me feel nearby them. Special thanks to Pedro who let me see the truth.

I would like to thank to all my teachers, administrative associates and classmates from Michigan Tech University no doubts it has been one of my best experiences.

I would like to extend my profound gratitude to the Gierke Family (John and Lynn), Bowman's Family (including Irene Corrales) and Elisa Piispa for becoming my family here. Thanks also to Briggite for showing her solidarity and hospitality.

I would especially like to thank Mirian Rios-Sanchez for all her invaluable help and for encouraging me, especially during the writing of this report and helping me revise my text.

Above all, many thanks to all my friends with whom Sofia and I shared many good times. I especially want to thank: Elisa, Luke, Marine, and Massimiliano for all the fresh air time we have had together; Kyung In, Marine, Elisa, Briggite and Ezequiel for being friends and for the many rides anytime. Priscilla for her cooking; Federica for all the presents for Sofia. Hans and Emily for those funny moments, finally all the rest of friends (Yoopers or not) I forgot to thank and that will understand that not naming them does not mean I do not thank them. 


\section{ABSTRACT}

Evidence suggests that a changing global climate is accelerating glacial retreat around the world. However, there are not many studies that help to understand the influence of climate change on glaciers in the tropical Andes. In many Andean countries, populations use the water that come from the high altitude mountains, especially mountains that are ice covered. Glacial reduction minimizes water resource availability. This report focuses on better understanding the relationship between glacier meltwater, surface water runoff, and the groundwater flowing into and under the Pita River upper watershed, which crosses the base of the northeast foothills of the Cotopaxi volcano. Available geospatial, meteorological, hydrogeological, and geochemical data were used in order to calculate the water balance, as well as to evaluate the chemical signature of the water sources for different creeks lakes and rivers into the study area. The results achieved in this work are the annual temperature is $8.41^{\circ} \mathrm{C}$, whereas the annual rainfall is $1320 \mathrm{~mm}$ and the evapotranspiration is around $38-43 \%$ of the precipitation value. Hydrological conditions generated a water yield in the watershed of $17.9 \mathrm{l} / \mathrm{s} / \mathrm{km}^{2}$. According to the relationship between area and discharge, for the Pita watershed with an area of $173 \mathrm{~km}^{2}$, the discharge corresponds to $3.1 \mathrm{~m}^{3} / \mathrm{s}$. Thus, the Cotopaxi hillslope contributes $33 \%$ to the total yield, which is equivalent to $1021 \mathrm{l} / \mathrm{s}$. The volume of the glacier retreat from 1996 to 2010 is $0.013 \mathrm{~km}^{3}$ and is considered as part of the glacier meltwater contribution. Regarding to the isotopic signature, all the samples taken show a mixture signature between the two possible sources, which means that there is infiltration in the upper part of the watershed and discharge in the lower part of it. These results were ascertained in the context of current climatic conditions in a conceptual model that will be used to estimate how the glacial contributions might change as a result of future climate changes and the impacts of these changes on water supplies in this region. 


\section{SECTION I: INTRODUCTION}

\subsection{Background}

The period since 1980 to 2012 has been considered the warmest at the earth's surface, and the temperature has been increasing by $0.85^{\circ} \mathrm{C}$ on average in three decades, causing rising sea levels and decreasing snow and ice production (IPCC, 2014). Some regions have been experiencing changes in precipitation patterns that are altering the hydrological cycle, especially impacting water resources in terms of quantity and quality, and also increasing flooding and landslides (IPCC, 2014).

The Tropical Glaciers of the Andes are located in high-elevation mountain ranges, which are very sensitive to climatic changes, especially to increasing temperature and changes in precipitation amounts and types (rain in lieu of snow), which is causing glaciers to retreat at an accelerating pace (UNESCO, 2012). The potential loss of the glaciers stands to threaten the well-being of the nearly 30 million people who are dependent on the water supplied from the glaciers for agriculture, human water consumption, electricity generation and livestock production (UNESCO, 2012). Since 1970, glaciers in the Andes have lost an estimated $20 \%$ of their volume. This dramatic reduction of glacial volume threatens large cities in the regions that are dependent on glacial runoff for their water supply (UNESCO, 2012).

The glacial retreat taking place in the Tropical Andes as a consequence of global climate change is causing continual reduction of glacial volume at Cotopaxi Volcano. According to Caceres et al. (2004), 31\% of the glacial volume on Cotopaxi volcano melted during the period of 1976-1997, and the trend is projected to continue. The diminishing glacial volume could threaten future water availability in Andean cities like Quito, which is the capital of Ecuador, and has a population of 2,239,191 (INEN, Censo Población y Vivienda, 2010). The metropolitan area requires approximately $8 \mathrm{~m}^{3} / \mathrm{s}$ of water supply given the current population and water usage. Most of the water supply comes from the "paramos" of the surrounding mountains. According to the Public Metropolitan Enterprise of Water Supply and Sanitation of Quito (Empresa Pública Metropolitana de Agua Potable y Saneamiento, EPMAPS) 30\% of the total water supply to Quito comes from the Cotopaxi Volcano watersheds and only $2 \%$ of the total is assumed to come from glacier meltwater (EPMAPS, 2014).

There is a lot of evidence that supports the hypothesis that a changing global climate is affecting glacial retreat around the world. However, there are not many studies that help to understand the influence of climate change on glaciers in the tropical Andes. EPMAPS has a principal interest in the proper management of water resources over the basins that are used for water supplies. For that reason, it has been embarking on a number of 
hydrological and hydrogeological studies to characterize current water resources in a way that will allow forecasting potential effects of climate and land use changes. However, the contributions of glacier meltwater to recharging groundwater systems remain unknown.

Addressing this literature gap is one of the scientific motivations for this project. Additionally, global changes have an important impact on overall water resource availability. In Andean countries, part of the population uses the water that comes from the high-altitude mountains; especially mountains that are ice covered. Thus, understanding the impact of the glacial reduction in regards to water resource availability has become my social motivation. Regarding these motivations, this study is aimed at understanding the relationship between glacier meltwater and the water that is flowing into and under the Pita River, which is a major source of municipal water supply for Quito.

\subsection{Objectives}

The first objective is to understand the relationship between the glacier meltwater and surface water and groundwater flowing into and under the Pita River upper watershed using available geospatial, meteorological, hydrogeological, and geochemical data.

The second objective is to enhance the understanding of the relationships between glaciers, precipitation and infiltration within intermountain aquifers systems.

\subsection{Physical description of the Upper Pita Watershed}

In order to obtain the morphometric parameters and other thematic maps for the Pita watershed, I have used the basic information available from EPMAPS and Fondo para el Agua (FONAG). This consists of digital topography and hydrography $(1: 25,000)$, and a 30-m resolution digital elevation model (DEM).

The watershed was delineated using a geographic information system (ArcGis 10.2.2) using the Arc Hydro GIS tool. It uses a methodology based on the analysis of DEM and streamline data.

The Upper Pita River Watershed (UPRW), which originates in southeastern part of Sincholagua volcano and northern part of Cotopaxi volcano, flows from south to north toward the southeastern flank of Pasochoa volcano (Figure 1.1). The UPRW is located between approximately 3280 and 5800 m.a.s.l., and the slope ranges as high as 55\%, with a mean of $11.22 \%$ (standard deviation of $8.5 \%$ ). (Figure 1.2). The study area covers approximately $173 \mathrm{~km}^{2}$, of which $67 \%\left(116 \mathrm{~km}^{2}\right)$ are part of the Sincholagua volcano hillslopes, whereas $33 \%$ of the total area $\left(57 \mathrm{~km}^{2}\right)$ is Cotopaxi volcano hillslopes. (Figure 1.3).

The drainage system mostly flows from south to north. The Mudadero River is its major tributary, which originates from the upper part of the Shincholagua volcano. 


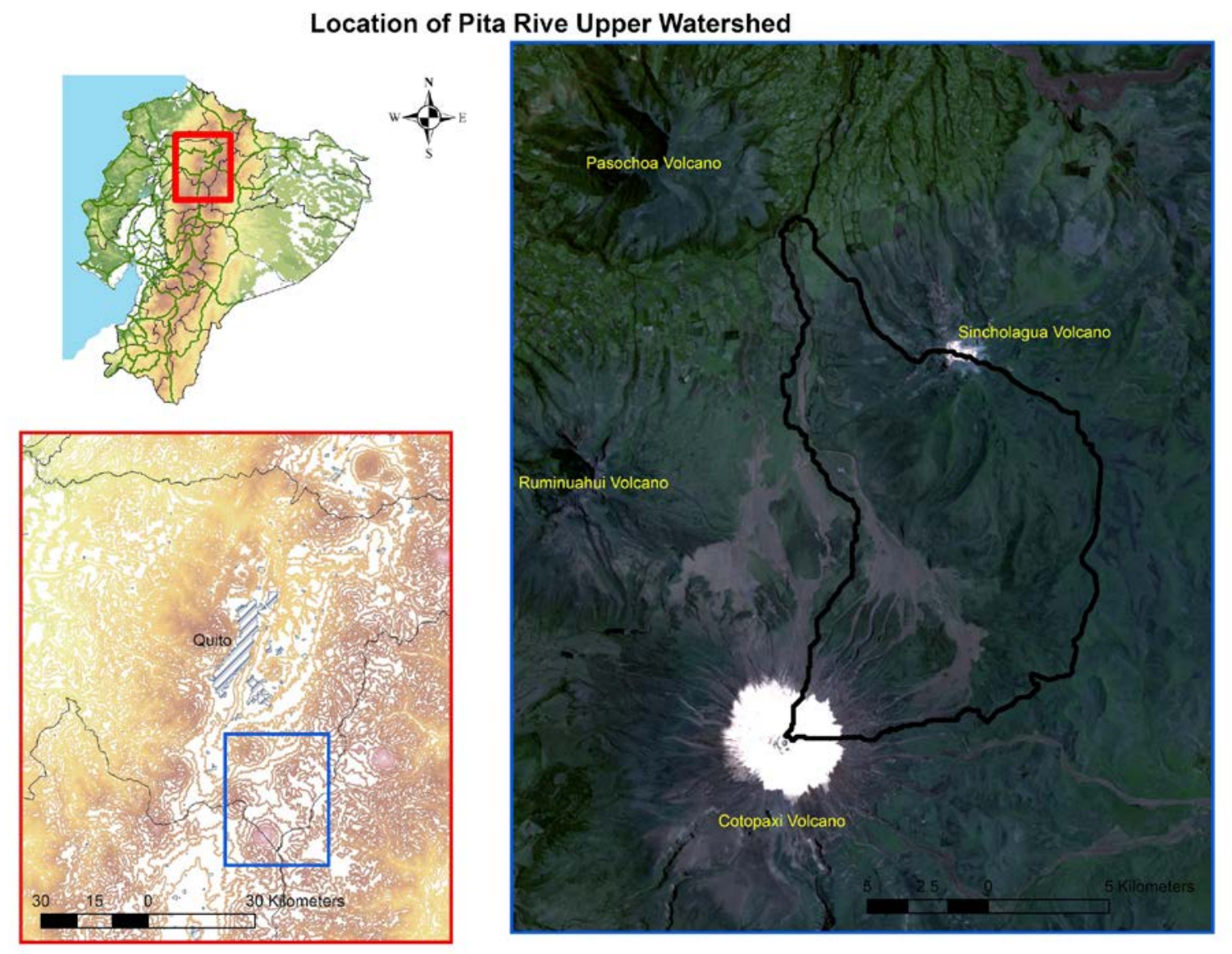

Figure 1.1 Location Pita River Upper Watershed (Source: topographic and political data from EPMAPS, Landsat 7, 2002, USGS) 


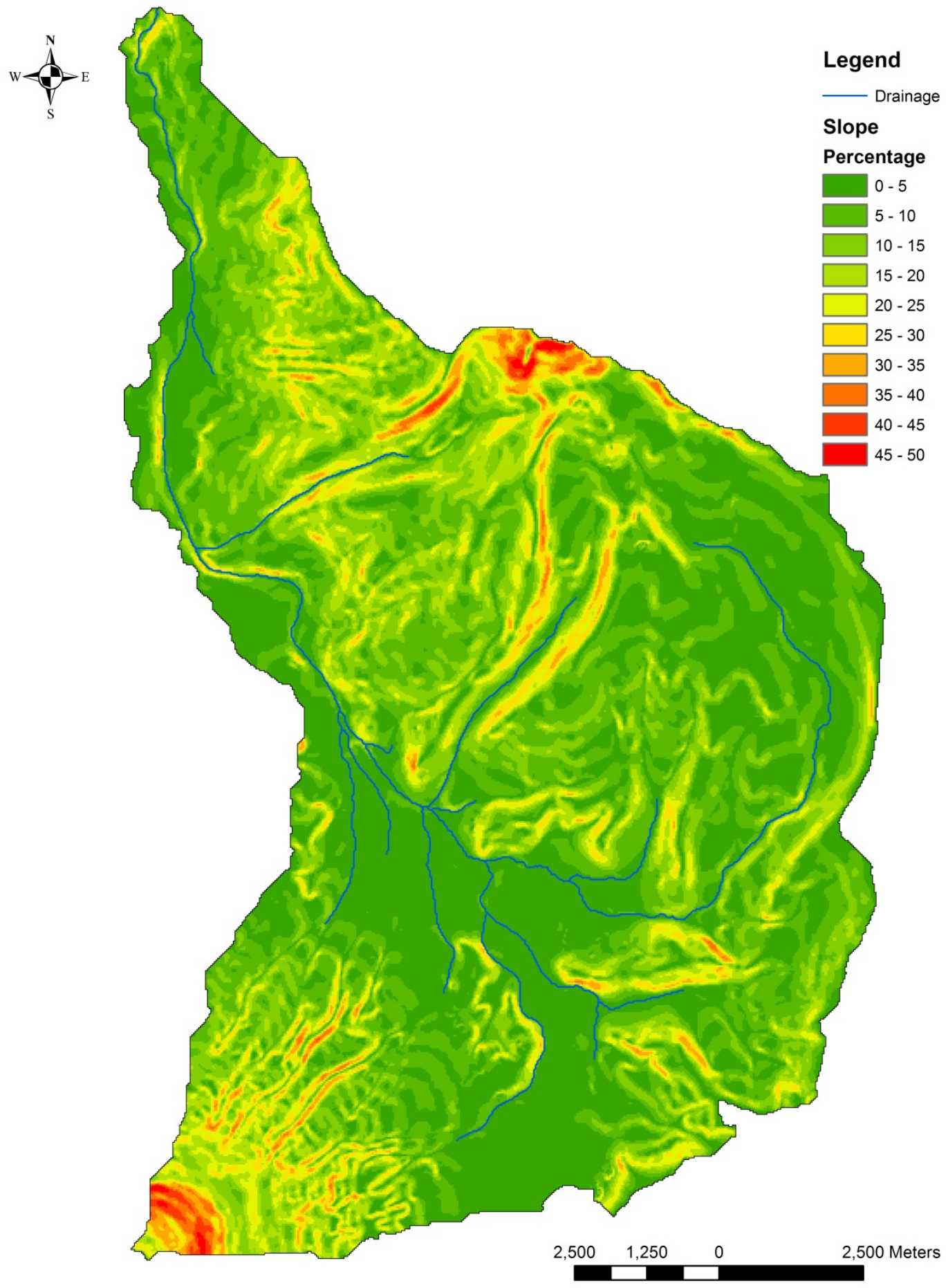

Figure 1.2 Pita watershed: Slope Map (Based on topographic information from EPMAPS) 


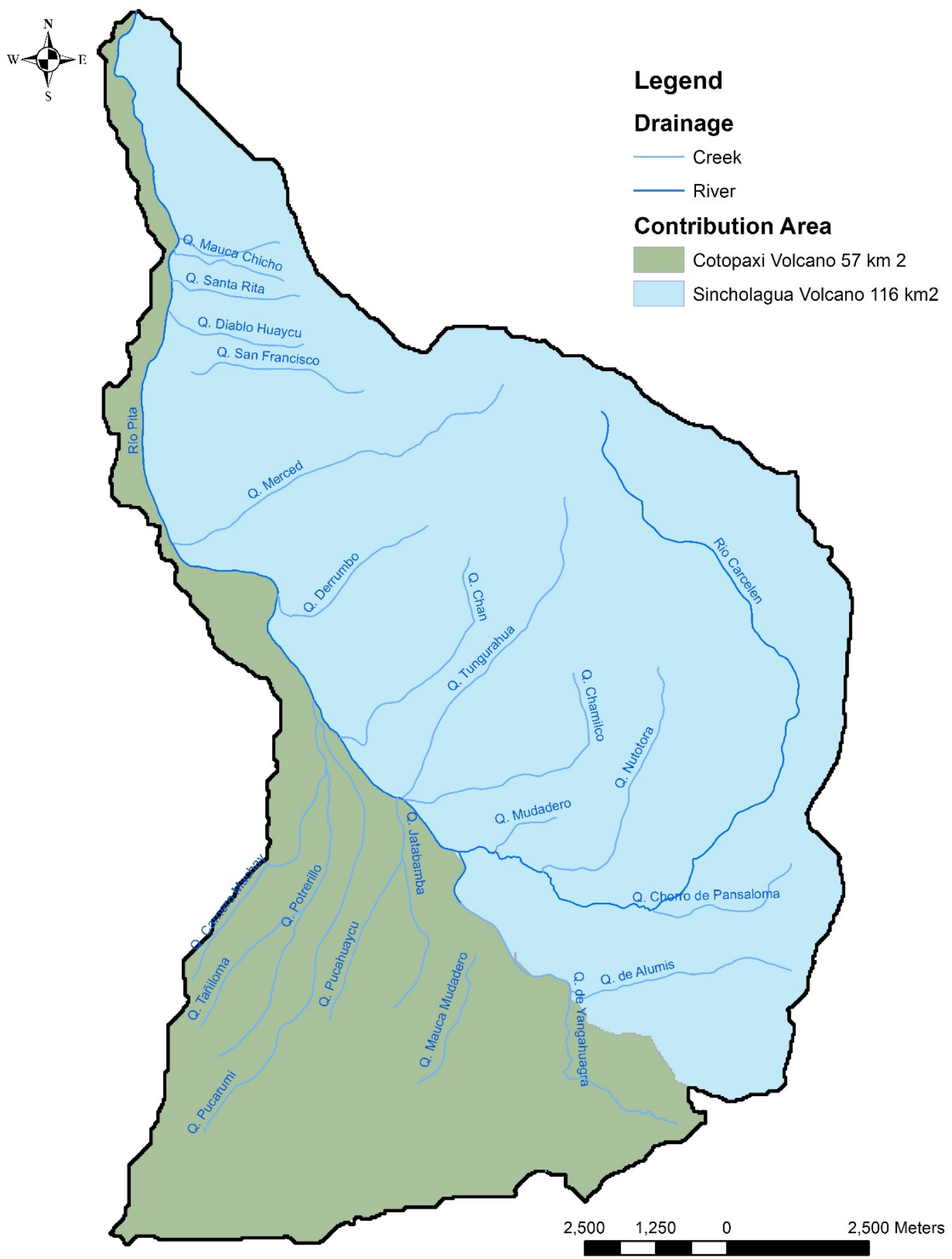

Figure 1.3 Map of Contribution area from Cotopaxi and Sincholagua Volcanoes 


\section{Land Use}

According to the data generated by Verduga and Zak (2008), 65\% of this study area is covered by paramo vegetation. (The paramo ecosystems are composed by soil organic and present high levels of endemic biodiversity (Mena Vasconez and Hofstede, 2006). These ecosystems have the capability for carbon stock and they are the major water source for mega-cities in the Andean highlands (Harden, 2006)). This study area is decreasing annually at a rate of $0.8 \%$ and being converted to pasture and eroded areas (TUCCI, C.E.M., 2009); pastures cover almost 20\%; eroded areas represent $12.5 \%$. (Figure 1.4). The paramos area benefits recharge, allowing for more retention and infiltration of water. Meanwhile the pasture areas would represents a risk in terms of water regulation capacity due to the fact that they are exposed to erosion from livestock (De Bièvre et al., 2012).

\section{Geology}

The Pita river watershed is located in the inter-Andean basin in which different depositional and transformational processes take place. Processes such as volcanism, deposition, sedimentation, tectonics and erosion have generated heterogeneous volcanosedimentary basin (Hall and Mothes, 2008).

The Pita river watershed is underlain by thick sequences of volcanic material, mainly composed of lava flows, volcanic bombs, lahars, lapilli, ash, and a broad area covered with debris flow deposits from past eruptions that extends over the entire perimeter of the base of the cone.

In order to understand the geological characteristics and its relationship with hydrology and hydrogeology processes in the study area, the following bibliographic review is presented. This review provides geological description of the different deposits using information from the Instituto Geofisico de la Escuela Politecnica Nacional (IG-EPN), such as geological and risk maps and research articles. Four cross sections were created using the geologic data from IG and average thickness reported by Hall and Mothes (2008).

\section{Stratigraphy}

Cotopaxi volcano is one of the most dangerous active volcanoes around the world, so it has been studied carefully in order to know the hazards that it can generate. As a result there are some risk and vulnerability maps made by scientist from IG-EPN. Hall and Mothes (2008) separate the Cotopaxi volcano stratigraphy into three eruptive periods named as Cotopaxi I, Cotopaxi II A and Cotopaxi II B.

The Cotopaxi I (560,000-300,000 years before present) consists of two series: the Barrancas Rhyolite Series and Detrital Fan and Andesitic Lavas. The Barrancas Rhyolite Series is characterized by tephra falls, ash flows, dome growth and collapse, and associated block-and-ash flows. The average thickness for this series is around $145 \mathrm{~m}$ (Hall and 
Mothes, 2008). This series is restricted to the southern part of the Cotopaxi Volcano, and for that reason it is not considered as part of the Pita watershed geology. The Detrital Fan and Andesitic Lavas are characterized by interbedded deposits of volcanic breccia, andesitic lavas, ash layers, and pyroclastic flows. Hall and Mothes (2008) reported that at the Bocatoma site, the sequence of debris flow, andesitic lavas and scoria flow are exposed.

The upper and lower Cangahua units (300,000-13,000 years before present) represent a regional fine-grained ashy tuffs product from eolian reworking of glacial loess and pumiceous ash from Chalupas and other rhyolitic eruptions. Thicknesses of this unit are reported as 25-30 m. The Chalupas Unit is a thick ash flow product of the eruption of Chalupas caldera 211,000 BP, which has a thickness between 10-15 m. (Hall and Mothes, 2008)

The Cotopaxi II A (13-4.5 Ky), has two series: the F Rhyolite Series and the Colorado Canyon Rhyolite Episode. The F Rhyolite Series consist of a 60 m-thick deposit from six episodes of ash flows, a dome-collapse flow, debris flows and minor andesitic scoria falls. The Colorado Canyon is a $164 \mathrm{~m}$-thick deposit that consists of products of rhyolitic activity such as dome growth, a rhyolitic breccia flow, a pumice lapilli fall, ash flows, and a debris flow as a product of the collapse of the northeast flank of Cotopaxi's cone (Hall and Mothes, 2008).

The Cotopaxi II B (4 Ky to present) consist of a 50 m-thick deposit that corresponds to historic andesitic activity whose products are characterized by pumice and scoria tephra falls, pyroclastic flows, blocky lava flows, and debris flows; especially the one of 1877 , which extends over the entire perimeter of the base of the cone (Hall and Mothes, 2008).

Figure 1.5 shows the approximate stratigraphy of Cotopaxi Volcano Area (Pita watershed) according to Hall and Mothes (2008). Figure 1.6 displays the geologic map of Cotopaxi volcano using the information available at IG.

To aid in understanding the hydrogeological setting of the study area, some cross sections were made based on the type of the deposit. Each cross section has different layers which were assumed to have the same lithological characteristics. I classified some deposits as debris flow and avalanche, ash flow and falls and dome and lavas, as shown in Figures 1.7.- cross sections A-A', Figure 1.8- cross sections B-B'; Figure 1.9 - cross sections CC'; and Figure 1.10 - cross sections D-D'. 


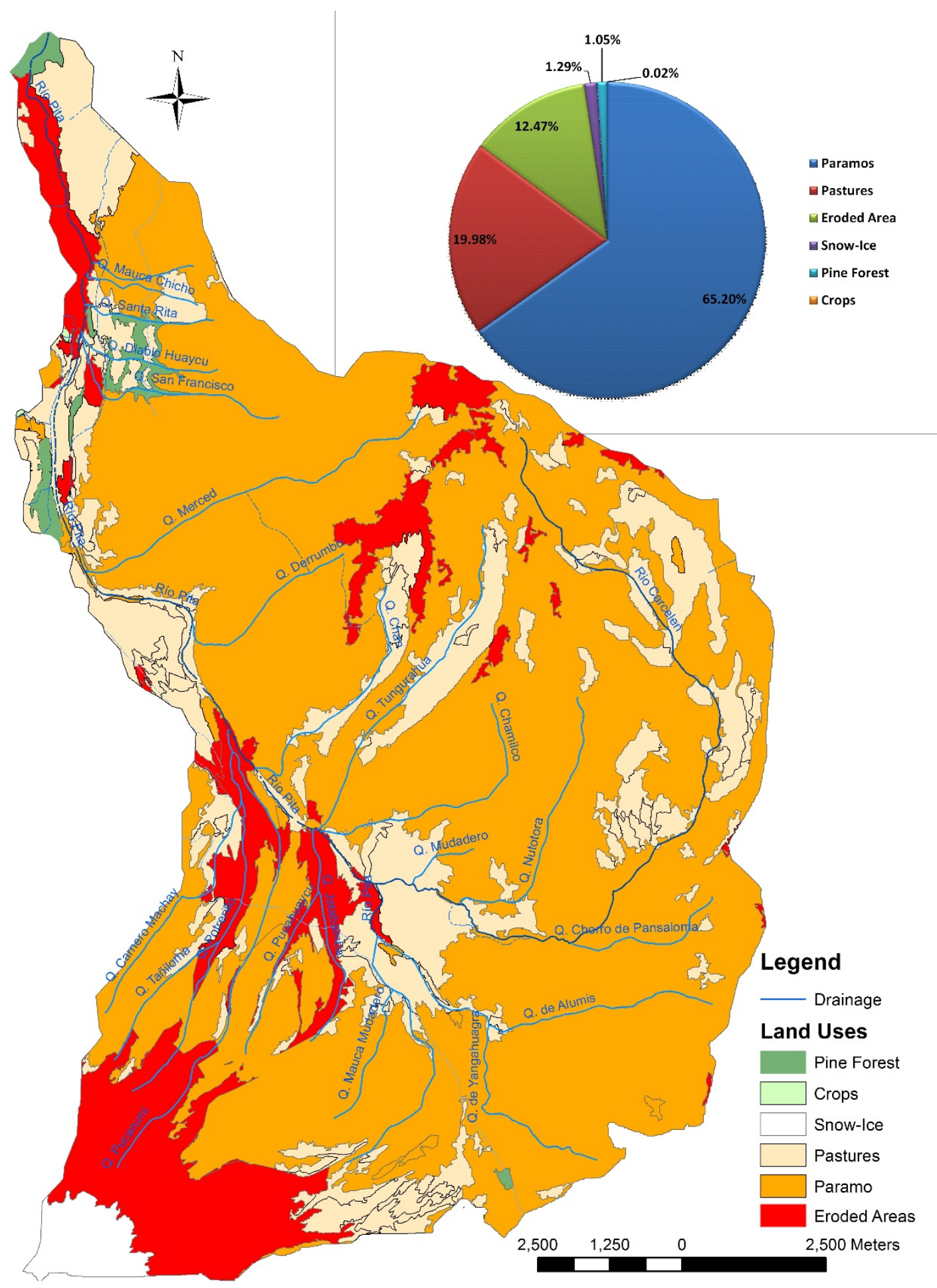

Figure 1.4 Map of Land Usage in the Upper Pita River Watershed (Data Source, 2007, De Bierve et al, 2008b in FONAG 2009) 


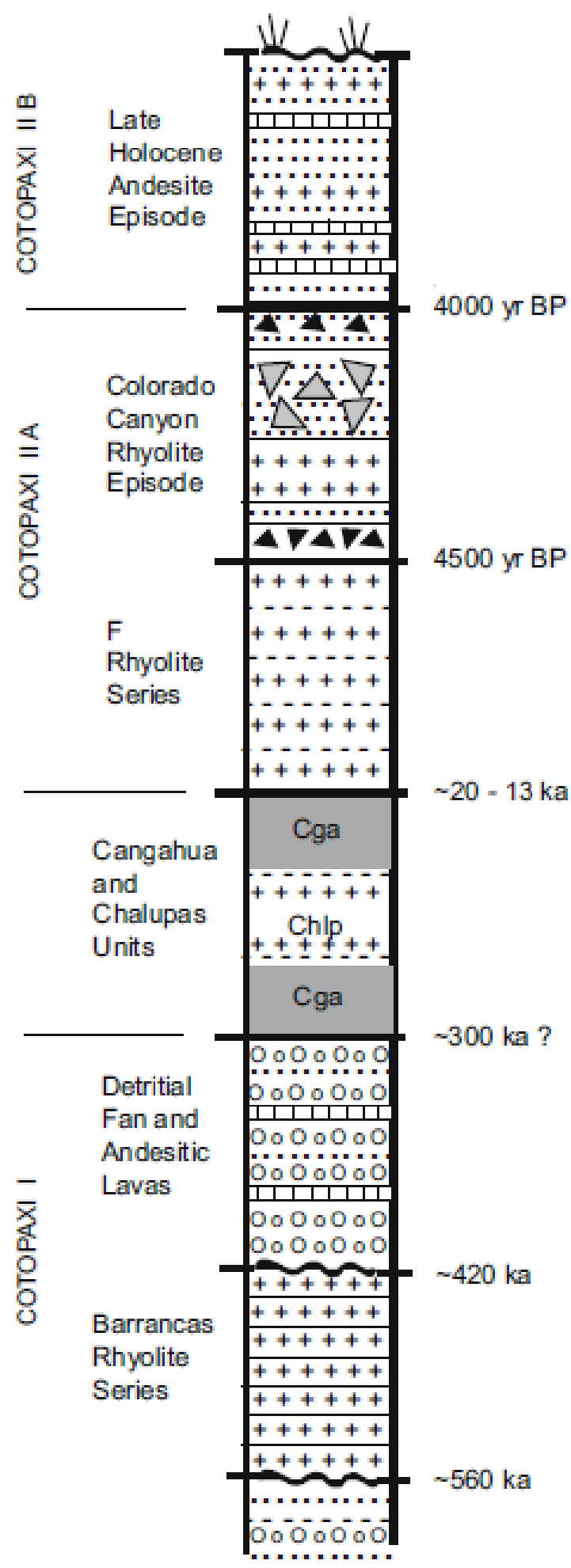

Figure 1.5 Stratigraphy of Cotopaxi Volcano Area (Pita watershed) Source Hall and Mothes (2008) 


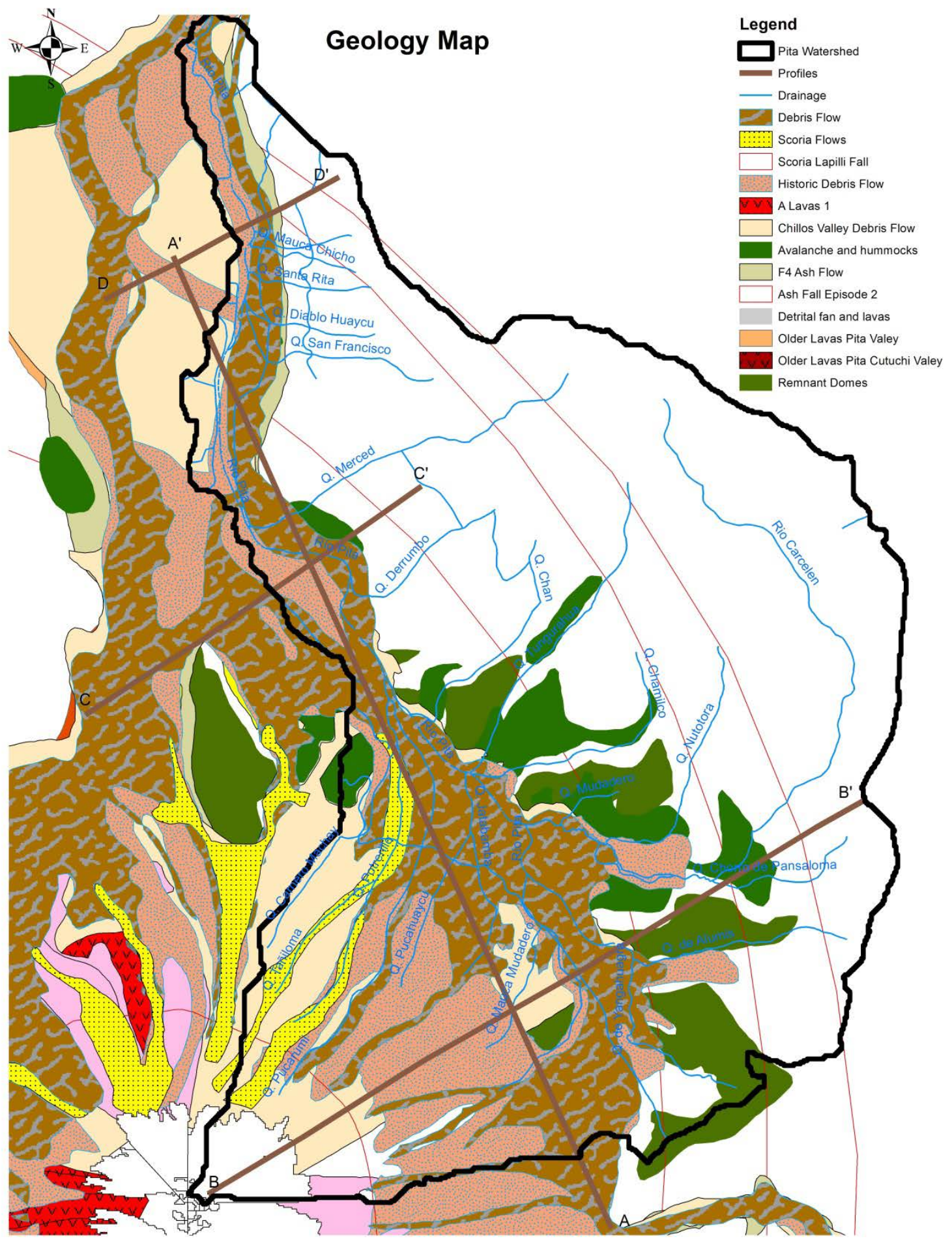

Figure 1.6 Geologic map of Cotopaxi Volcano - area upper Pita watershed. (Source IG 2007 Hall \& Mothes 2008) 


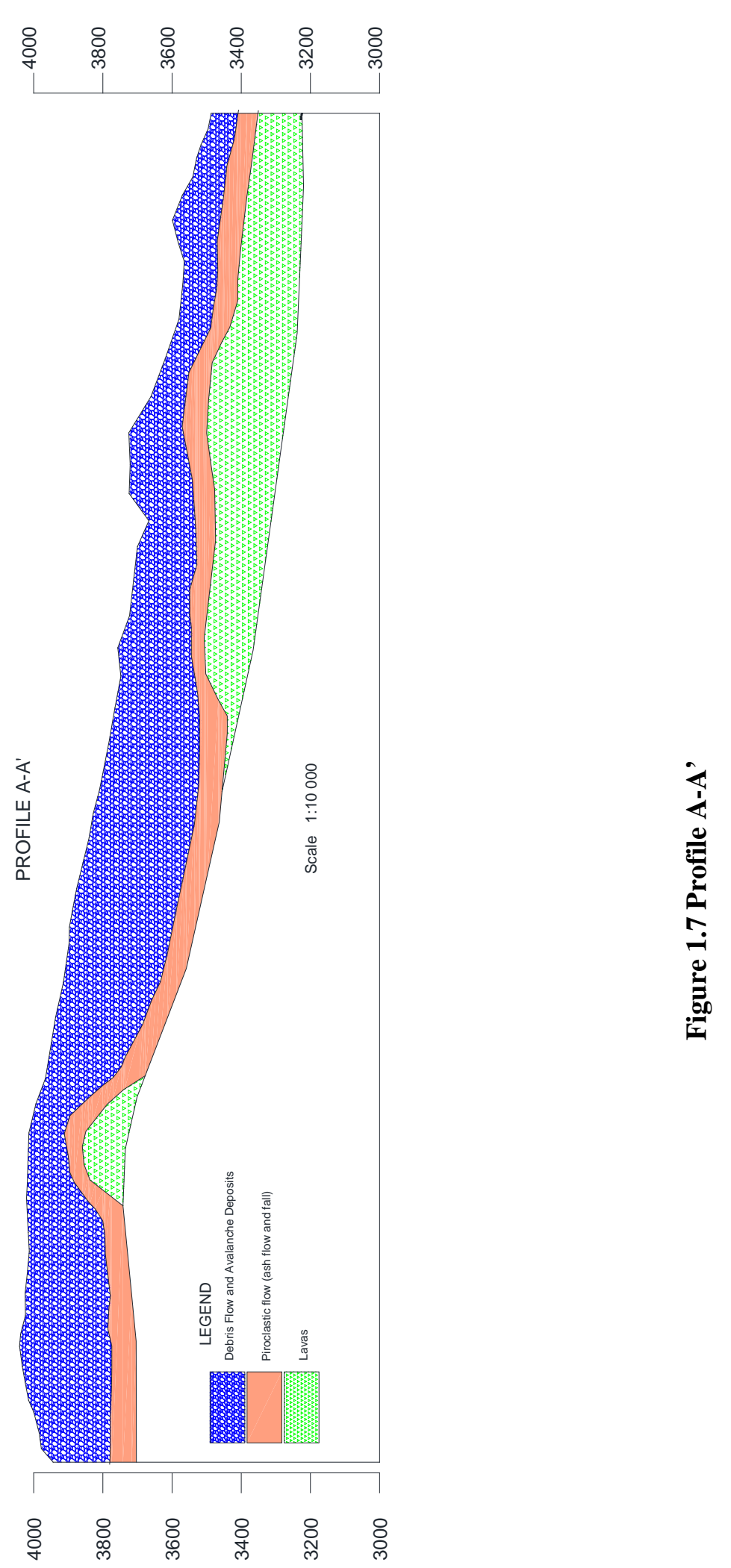




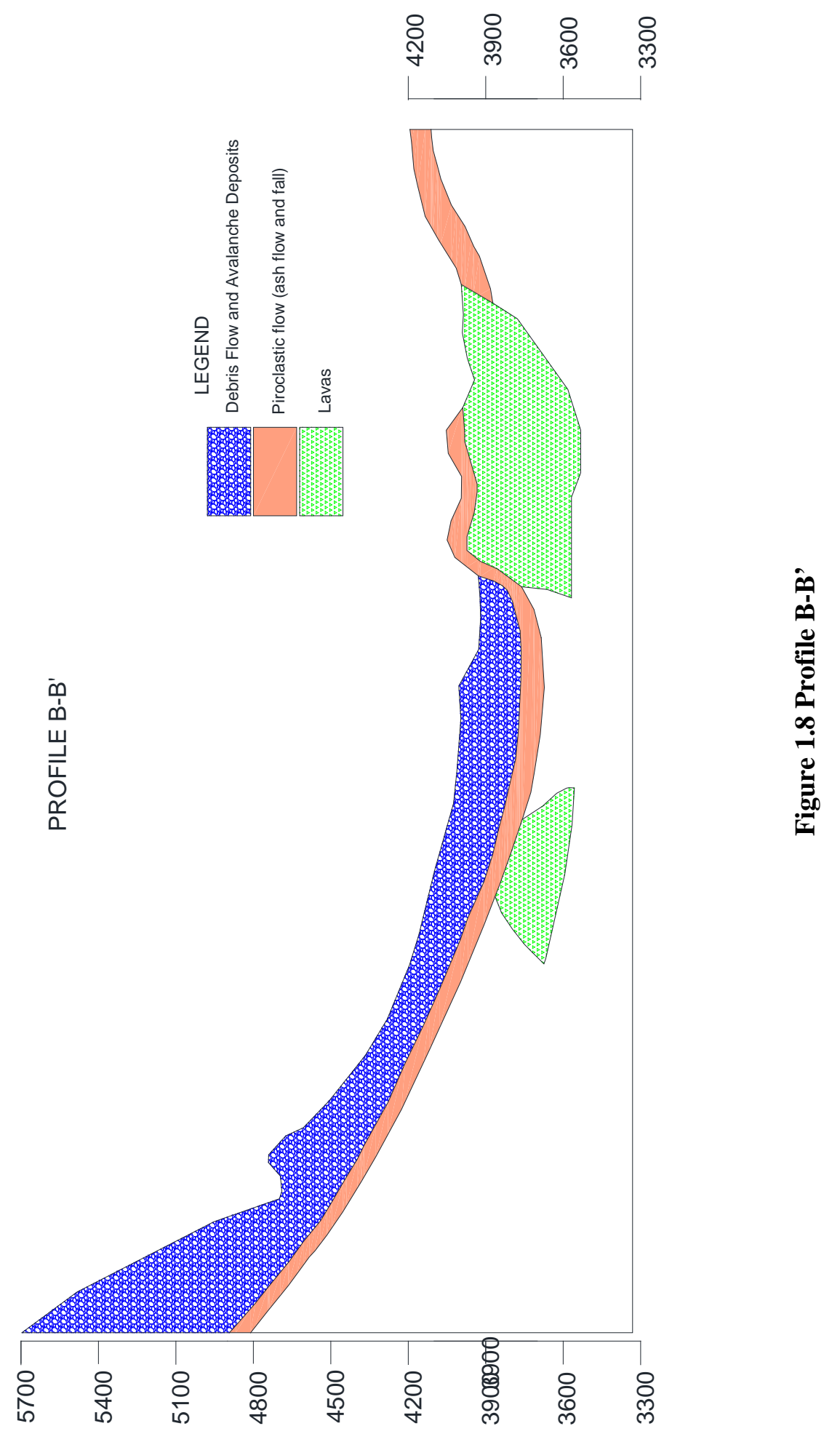



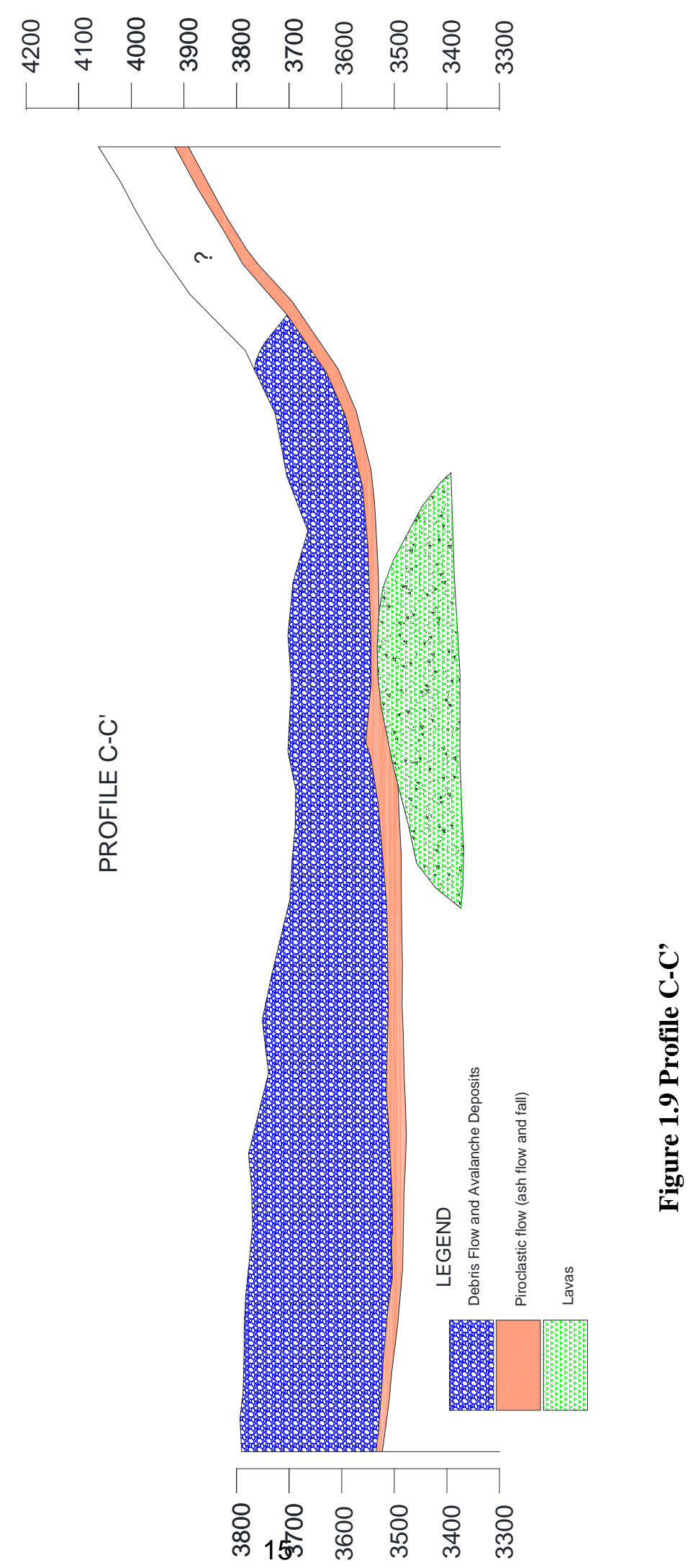


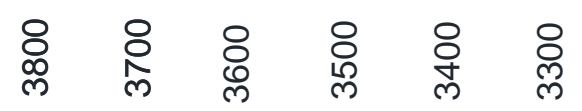

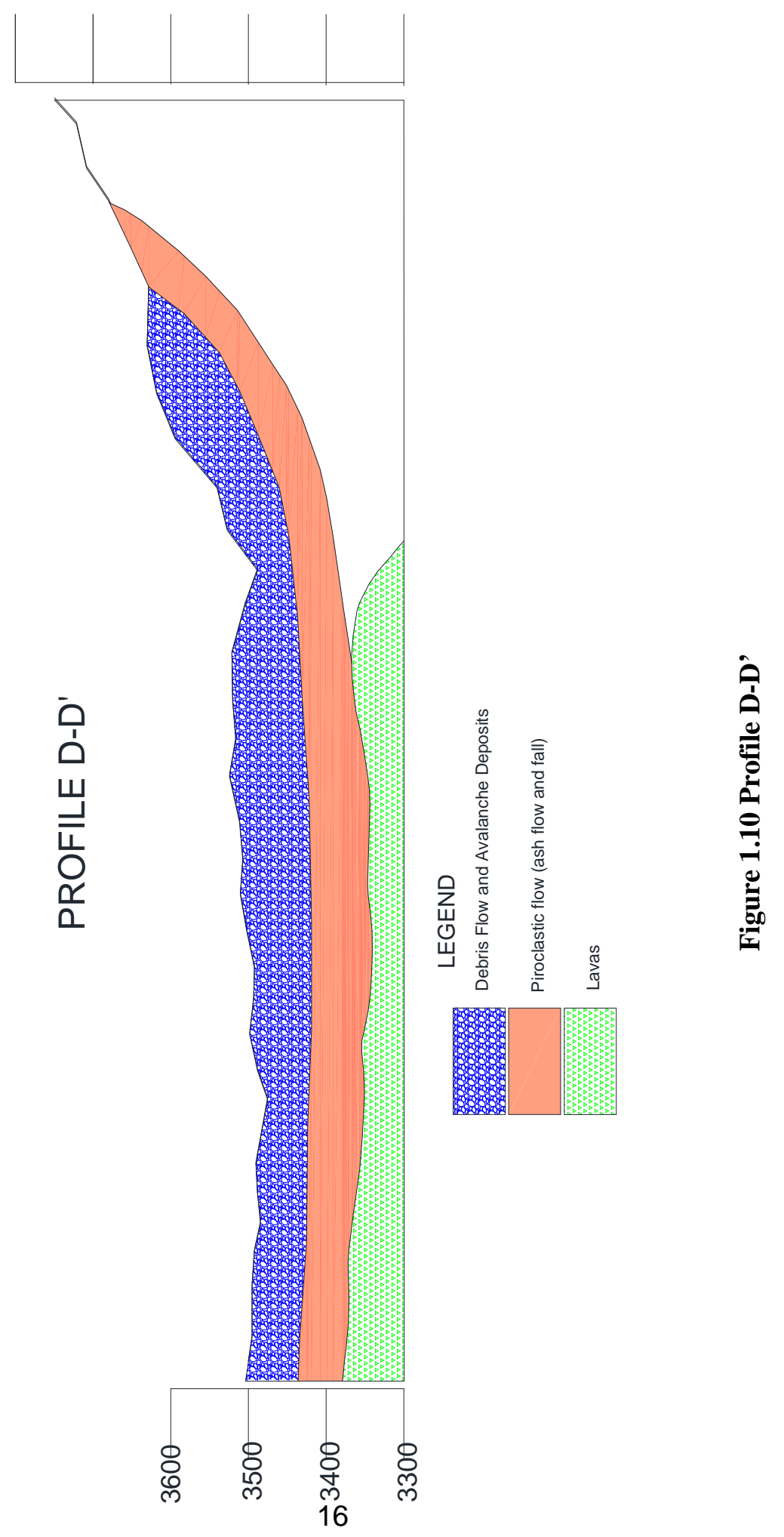




\section{Mineralogy and geochemistry of the rocks}

According to Hall and Mothes (2008), the mineralogical analysis reported for the rocks present in the area is shown in Table 1.1. The most minerals are sodic-calcic and ferricmagnesic. The chemical composition of these rocks is important because it affects the water that infiltrates the rocks due to a dissolution processes.

Table 1.1 Mineralogy of the Cotopaxi volcano deposits (Source Hall and Mothes, 2008)

\begin{tabular}{|c|c|c|}
\hline \multicolumn{3}{|l|}{ Andesitic Lavas (Bocatoma) } \\
\hline Mineral & Chemical Formula & Percentage \\
\hline Plagioclase & $(\mathrm{Na}, \mathrm{Ca})(\mathrm{Si}, \mathrm{Al})_{4} \mathrm{O}_{8}$ & $3-20 \%$ \\
\hline Hypersthene & $\left(\mathrm{Mg}, \mathrm{Fe}^{2+}\right)_{2} \mathrm{Si}_{2} \mathrm{O}_{6}$ & $10-20 \%$ \\
\hline Augite & $(\mathrm{Ca}, \mathrm{Na})(\mathrm{Mg}, \mathrm{Fe}, \mathrm{Al}, \mathrm{Ti})(\mathrm{Si}, \mathrm{Al}) 2 \mathrm{O} 6$ & $5-10 \%$ \\
\hline Olivine & $(\mathrm{Mg}, \mathrm{Fe}) 2 \mathrm{SiO} 4$ & \\
\hline \multicolumn{3}{|l|}{ Ash Flow (Bocatoma) } \\
\hline Matrix & & $75-78 \%$ \\
\hline Plagioclase & $(\mathrm{Na}, \mathrm{Ca})(\mathrm{Si}, \mathrm{Al}) 4 \mathrm{O} 8$ & \multirow[t]{2}{*}{$15 \%$} \\
\hline Quartz & $\mathrm{SiO} 2$ & \\
\hline Amphibole & NaCa2(Mg,Fe,Al)5(Al,Si)8O22(OH)2 & $5 \%$ \\
\hline Biotite & $\mathrm{K}(\mathrm{Mg}, \mathrm{Fe}+2) 3[\mathrm{AlSi} 3 \mathrm{O} 10(\mathrm{OH}, \mathrm{F}) 2$ & \multirow[t]{3}{*}{$1 \%$} \\
\hline Magnetite & $(\mathrm{Fe}+2 \mathrm{Fe}+3) 2 \mathrm{O} 4$ & \\
\hline Hypersthene & $(\mathrm{Mg}, \mathrm{Fe}+2) 2 \mathrm{Si} 2 \mathrm{O} 6$ & \\
\hline \multicolumn{3}{|c|}{ Ash Flow and Chillos valley lahar (pumice clasts 92\%) } \\
\hline Plagioclase & $(\mathrm{Na}, \mathrm{Ca})(\mathrm{Si}, \mathrm{Al}) 4 \mathrm{O} 8$ & $8 \%$ \\
\hline Biotite & $\mathrm{K}(\mathrm{Mg}, \mathrm{Fe}+2) 3[\mathrm{AlSi} 3 \mathrm{O} 10(\mathrm{OH}, \mathrm{F}) 2$ & \multirow[t]{3}{*}{$2 \%$} \\
\hline Magnetite & $(\mathrm{Fe}+2 \mathrm{Fe}+3) 2 \mathrm{O} 4$ & \\
\hline Quartz & $\mathrm{SiO} 2$ & \\
\hline Aphryric rhyolite and obsidian & $\mathrm{SiO} 2$ & $1 \%$ \\
\hline \multicolumn{3}{|c|}{ Andesitic Lavas (Cotopaxi IIB) } \\
\hline Augite & $(\mathrm{Ca}, \mathrm{Na})(\mathrm{Mg}, \mathrm{Fe}, \mathrm{Al})(\mathrm{Al}, \mathrm{Si}) 2 \mathrm{O} 6$ & $5-10 \%$ \\
\hline Hypersthene & $(\mathrm{Mg}, \mathrm{Fe}) \mathrm{SiO}_{3}$ & $10-20 \%$ \\
\hline Plagioclase & $(\mathrm{Na}, \mathrm{Ca})(\mathrm{Si}, \mathrm{Al}) 4 \mathrm{O} 8$ & $3-20 \%$ \\
\hline
\end{tabular}




\section{Hydrogeology}

The hydrogeological characteristics of the rock formations in the Pita watershed were categorized based on regional information generated by Instituto Nacional de Meteorología e Hidrologia (INAMHI) and Petroecuador, as well as from local information generated by EPMAPS.

The Inter-Andean region is occupied by series of basins with subsided tectonic source. These have been filled with detrital sediments and volcanic materials that were products of intense volcanic activity and erosion. In these regions, local and discontinuous aquifers have developed, and their permeability generally varies from low-medium and medium performance (INAMHI, 2011).

INAMHI defined the hydrogeological units of Ecuador in 1983. Each one of them has the main elements of geometry, geological heterogeneity aquifer productivity, piezometric levels, water depth, chemical quality, and average annual recharge.

The Pita river watershed is located in the Quito-Machachi hydrogeological unit. This is characterized by local aquifers with permeability from very low to medium depending on the type of deposits (Figure 1.11). In 2006, EPMAPS employed new field methods and established that the Pita watershed area is an unconfined aquifer that involves three types of deposits: fractured lavas, pyroclastic flows, and lahar deposits. The lahar deposits are unconsolidated to lightly cemented, which presents medium to low permeability, respectively. The lava flows have high secondary porosity and thus high permeability. The pyroclastic flows have high porosity, but because they are fine grained, have very low permeability. These layers are deeper and have been considered as the hydrogeological basement. Additionally, based on well drillers' reports, the ground water levels are approximately at 45-m depth.

According to the lithological description from Hall and Mothes (2008), the best formations for providing water consist of debris flow and avalanche products, and these are considered to be the unconfined aquifer described by EPMAPS (2006). Moreover, the deposits that involve ash flows and falls could be considered as the very low permeability layer described by EPMAPS (2006). The lava deposits, however, are not present in the entire area and those deposits present secondary porosity. As a result, these lava deposits could not be considered as basement—instead, it can be considered as a deep aquifer, whose basement is unknown. As can be inferred from the cross sections A-A'-Figure 1.7, B-B'-Figure 1.8, C-C' - Figure 1.9 and D-D' Figure 1.10, where the precipitation and glacial melt water are infiltrating uphill, the infiltrating water flows through the debris flow and avalanche deposits and form the unconfined aquifer. 


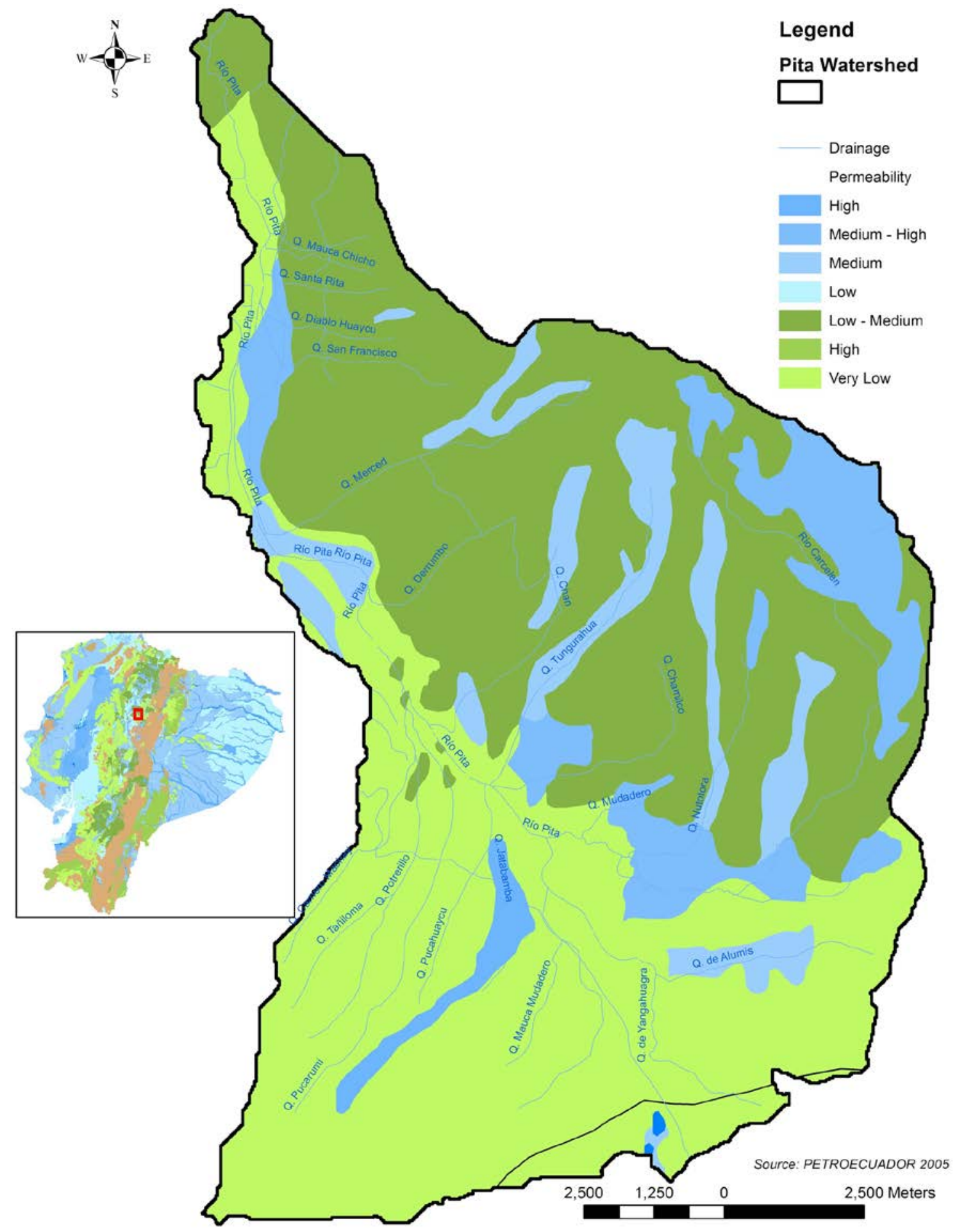

Figure 1.11 Permeability map in upper Pita watershed (Source Petroecuador, 2005) 


\subsection{General methodology \\ Geospatial data}

Basic information, outlined below, available from EPMAPS, FONAG, INAMHI and IG were used to obtain the morphometric parameters and other thematic maps for the Upper Pita River watershed. The available information included: digital topography and hydrography (1:25000), digital elevation model (DEM) resolution $30 \mathrm{~m}$ by $30 \mathrm{~m}$, and glacier boundaries from different years. Additionally the database, with location and descriptions of the meteorological and hydrologic stations, were obtained from EPMAPS and INAMHI. I have used ArcGis 10.2.2 for all the analysis and figure generation.

\section{Meteorological data}

A water balance was calculated using mean monthly precipitation, temperature and discharge data from EPMAPS monitoring network (12 year period from 2003-2014) and from INAMHI, which are part of the national meteorological network (10 years of mean monthly precipitation).

Table 1.2 Stations available in the area for precipitation.

\begin{tabular}{|l|l|l|l|}
\hline CODE & NAME & INSTITUTION & PERIOD \\
\hline C1 & Maucatambo & EPMAPS & $2003-2014$ \\
\hline P35 & Pita Bocatoma & EPMAPS & $2003-2014$ \\
\hline P39 & Yangahuagra & EPMAPS & $2003-2014$ \\
\hline M120 & Cotopaxi-Clirsen & INAMHI & $2003-2012$ \\
\hline M364 & Loreto Pedregal & INAMHI & $2003-2012$ \\
\hline
\end{tabular}

Temperature data from EPMAPS consists of a series of different annual periods: four years (2011-2014) for Pita-Bocatoma station and six years (2007-2012) for Maucatambo station were obtained. Whereas from INAMHI, 23 years (1978-2000) for Cotopaxi-Refugio station and six years (2008-2013) for Cotopaxi station were used. As shown in Table 1.3

Table 1.3 Stations available in the area for temperature.

\begin{tabular}{|l|l|l|l|}
\hline CODE & NAME & INSTITUTION & PERIOD \\
\hline C1 & Maucatambo & EPMAPS & $2007-2012$ \\
\hline P35 & Pita Bocatoma & EPMAPS & $2011-2014$ \\
\hline M120 & Cotopaxi-Refugio & INAMHI & $1978-2000$ \\
\hline M121 & Cotopaxi & INAMHI & $2008-2013$ \\
\hline
\end{tabular}




\section{Hydrological Data}

Daily discharge was obtained from EPMAPS from the following stations presented in table 1.3.

Table 1.3 Stations available in the area for discharge.

\begin{tabular}{|l|l|l|l|}
\hline CODE & NAME & INSTITUTION & PERIOD \\
\hline PT16 & Proaño & EPMAPS & $2000-2015$ \\
\hline H12 & Bocatoma Pita & EPMAPS & $2003-2014$ \\
\hline PT04 & Salitre & EPMAPS & $2003-2015$ \\
\hline PT02 & Rio Pita AJ Mudadero & EPMAPS & $2003-2015$ \\
\hline PT03 & Rio Mudadero AJ Río Pita & EPMAPS & $2003-2015$ \\
\hline TT26 & Alumis in Mudadero & EPMAPS & $2004-2015$ \\
\hline N158 & Pita AJ Salto & INAMHI & $2000-2008$ \\
\hline
\end{tabular}

\section{Geology and Hydrogeology}

In order to analyze the geology and hydrogeology, the geological map and interpretations provided by the Geophysical Institute were used (Hall and Mothes, 2008). Additionally, I used hydrogeological data available from some government institutions such as Petroecuador, INAMHI and EPMAPS.

\section{Chemistry and Isotopic Tracers}

To evaluate the chemical signature of the water sources, samples were collected at some selected creeks and points along the Pita River in the study area. The samples were analyzed by the EPMAPS laboratory for major and minor elements; whereas for the isotopic elements, the samples were analyzed at Soil, Water, \& Climate Laboratory at the University of Minnesota. The software used to analyze the data included the GeoStiff program developed by Texas Water Development Board and the Piper spreadsheet developed by Spreadsheet developed by Enric Vàzquez Suñé, 1999 updated 2001. 


\section{SECTION II: HYDROLOGICAL CHARACTERIZATION}

The climate conditions of Ecuador are affected by factors such as wind currents towards and away from the ocean, latitude, altitude, vegetation and topography, especially near the mountainous regions. The Pita River is located on the western slopes of the Cordillera Real, and it is strongly influenced by the presence of mountain ranges that surround the study area and whose natural drainage leads its waters towards the inter-Andean region and then flow into the Pacific Ocean. The upper Pita River watershed (Figure 1.1) is strongly influenced by the Amazon and ocean climate patterns. The climate is considered an "equatorial cold high mountain" (Pourrut, 1995). However, physical factors such as relief, morphology, slope, latitude, exposure to moist air masses, and wind direction make the study area experience a variety of microclimates with changes in spatial distribution conditions, especially in the variability of rainfall.

The principal objective of this section is to obtain the meteorological conditions and their variations through time, considering that they are the most important factors that determine the hydrological response within a watershed.

\subsection{Precipitation Analysis}

There are several methods in ArcGIS that interpolate data. The Kriging and IDW methods were used in this work. Kriging method quantifies the spatial data structure using statistics, in this case variograms and semivariograms; due to its similarity in the calculations and predictions by interpolation, it is assumed that the closest known point data have greater weight or influence. The interpolation influence decrease as it moves away from the landmark. The Inverse Distance Weighting (IDW) is a deterministic method which gives more weight to values close to a point but has lower computational complexity. IDW uses a simple algorithm based on distances. Because the distance between points to interpolate is big, the IDW method was chosen.

Based on the available daily data, average monthly and annual precipitation was calculated for four stations, located in the watershed or very close to it. Spatial distributions of annual precipitation were calculated as well using the ArcGIS Spatial Analyst module. Inverse distance weighted (IDW) was used as the interpolation method. Station names, years of records, and source are listed in Table 2.1. Locations are indicated on Figure 2.1.

In this work the parameters that were used in the IDW interpolation method are basically the default values: the cell size of the output raster was the default value 117. This value is considered to be the shorter of the width or the height of the extent of the input point features, in the input spatial reference, divided by 250; the exponent of distance, which controls the significance of surrounding points on the interpolated value, was considered the default 2 . The search radius defines which of the input points will be used to interpolate 
the value for each cell in the output raster, in this case the default value 12 point was used (ArcGIS, 2015).

Table 2.1 Location of the rain stations and Annual Precipitation in mm. (Source: $M$ station belongs to INAHMI, the others belong to EPMAPS).

\begin{tabular}{|l|l|c|c|c|c|c|}
\hline \multicolumn{1}{|c}{ Code } & \multicolumn{1}{c}{ Name } & $\begin{array}{c}\text { Easting } \\
(\mathbf{m})\end{array}$ & $\begin{array}{c}\text { Northing } \\
(\mathbf{m})\end{array}$ & $\begin{array}{c}\text { Altitude } \\
\text { (mamsl) }\end{array}$ & $\begin{array}{c}\text { Time } \\
\text { Period }\end{array}$ & $\begin{array}{c}\text { Annual Average } \\
\text { Rain *(mm) }\end{array}$ \\
\hline P35 & Pita Bocatoma & 785046 & 9945051 & 3360 & $2003-2014$ & 1471.69 \\
\hline M364 & Loreto Pedregal & 786223 & 9937519 & 3620 & $2003-2012$ & 1466.91 \\
\hline C1 & Maucatambo & 794900 & 9925334 & 3845 & $2003-2014$ & 1192.17 \\
\hline P39 & Yangahuagra & 796025 & 9928284 & 4040 & $2003-2014$ & 1144.24 \\
\hline \multicolumn{7}{|c|}{ *Annual average values are monthly cumulative values } \\
\hline
\end{tabular}

\section{Results}

Annual precipitation in the study area ranges from $1144 \mathrm{~mm}$ to $1471 \mathrm{~mm}$. Monthly precipitation calculations indicate a bimodal distribution for the stations Pita-Bocatoma and Loreto-Pedregal, located in the north-central part of the watershed. For these stations, the rainiest months occur during the months of April (198 and $193 \mathrm{~mm}$, respectively) and November (191 and $193.74 \mathrm{~mm}$, respectively). The driest month is August (26 and $34 \mathrm{~mm}$, respectively). For the other two stations; Maucatambo and Yangahuagra, located on the eastern part of the watershed, a unimodal distribution was observed, with the wettest month being June (146 and $143 \mathrm{~mm}$, respectively) and the driest January (64 and $69 \mathrm{~mm}$, respectively). See also Table 2.2 and Figures 2.2 and 2.3.

The annual isohyet map (Figure 2.3) indicate an inverse relation to the topographic elevation. The largest amounts of rainfall toward the southern part of the watershed correspond to the lowest topographic areas. Conversely, the highest topographic areas have the lowest precipitation. Figures 2.4 and 2.5 show annual precipitation values for the two stations in the lower part of the study area (Loreto Pedregal and Pita Bocatoma) and the two stations in the higher part (Maucatambo and Yangahuagra), respectively. 


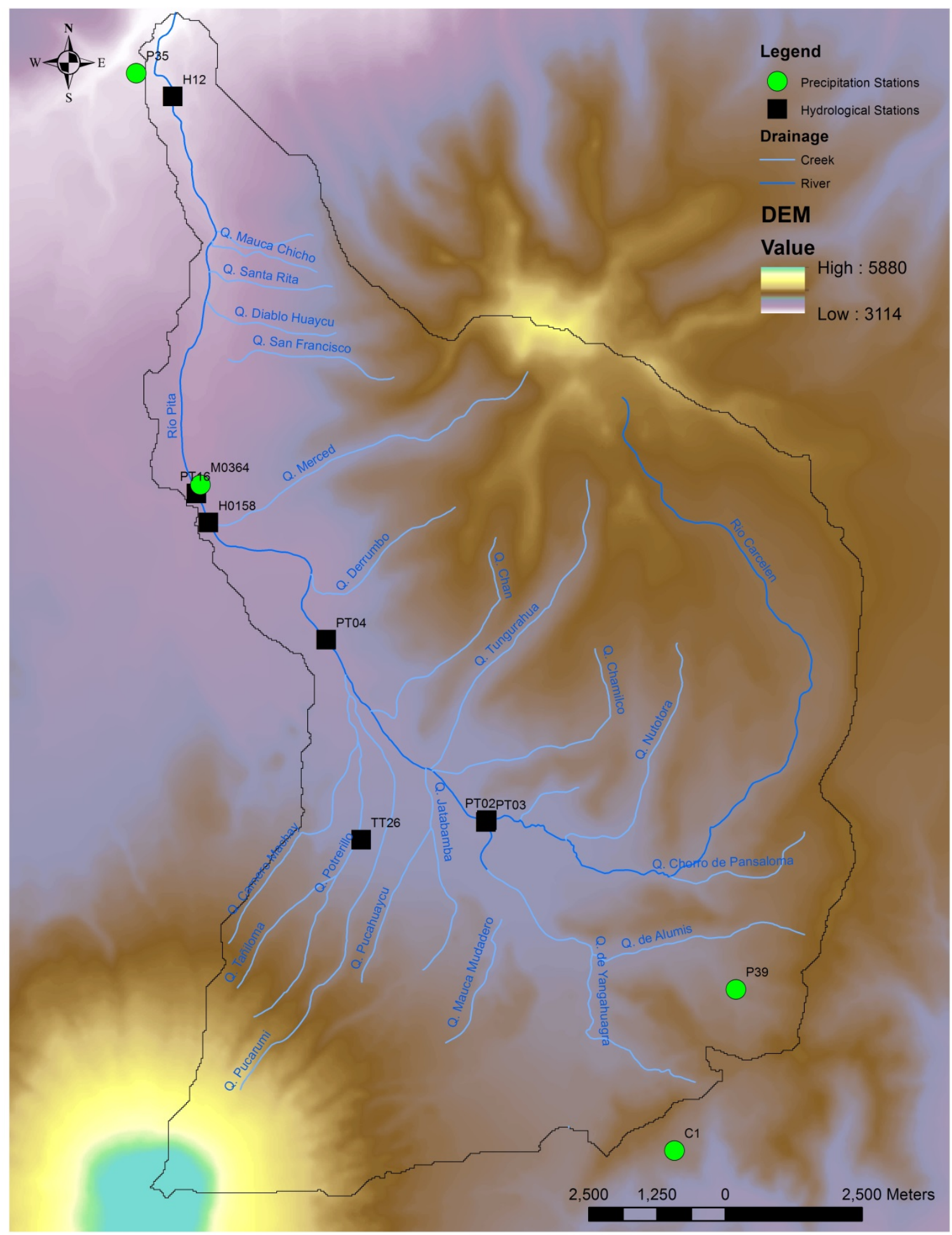

Figure 2.1 Location of the precipitation and hydrological stations in the study area (Source topographic base information EPMAPS, Precipitation station from EPMAPS and INAMHI, hydrological station from EPMAPS) 
Table 2.2 Monthly precipitation at rain stations. Amounts presented in mm. (Source: M station belongs to INAHMI, the others belong to EPMAPS).

\begin{tabular}{|c|c|c|c|c|c|c|c|c|c|c|c|c|}
\hline Code & JAN & FEB & MAR & APR & MAY & JUN & JUL & AUG & SEP & OCT & NOV & DEC \\
\hline P35 & 142.25 & 163.10 & 176.05 & 182.54 & 126.45 & 65.90 & 31.22 & 27.50 & 53.24 & 146.59 & 182.12 & $\begin{array}{c}174.7 \\
3 \\
\end{array}$ \\
\hline M364 & 149.97 & 161.82 & 153.01 & 193.42 & 116.17 & 53.36 & 54.89 & 34.24 & 87.36 & 159.81 & 193.74 & $\begin{array}{c}181.8 \\
7\end{array}$ \\
\hline $\mathrm{C} 1$ & 64.66 & 88.27 & 95.02 & 128.46 & 132.84 & 146.65 & 117.06 & 93.93 & 79.34 & 86.65 & 79.31 & 87.27 \\
\hline P39 & 69.30 & 75.43 & 87.55 & 115.22 & 118.24 & 143.26 & 111.18 & 95.76 & 80.67 & 83.15 & 79.48 & 85.02 \\
\hline
\end{tabular}

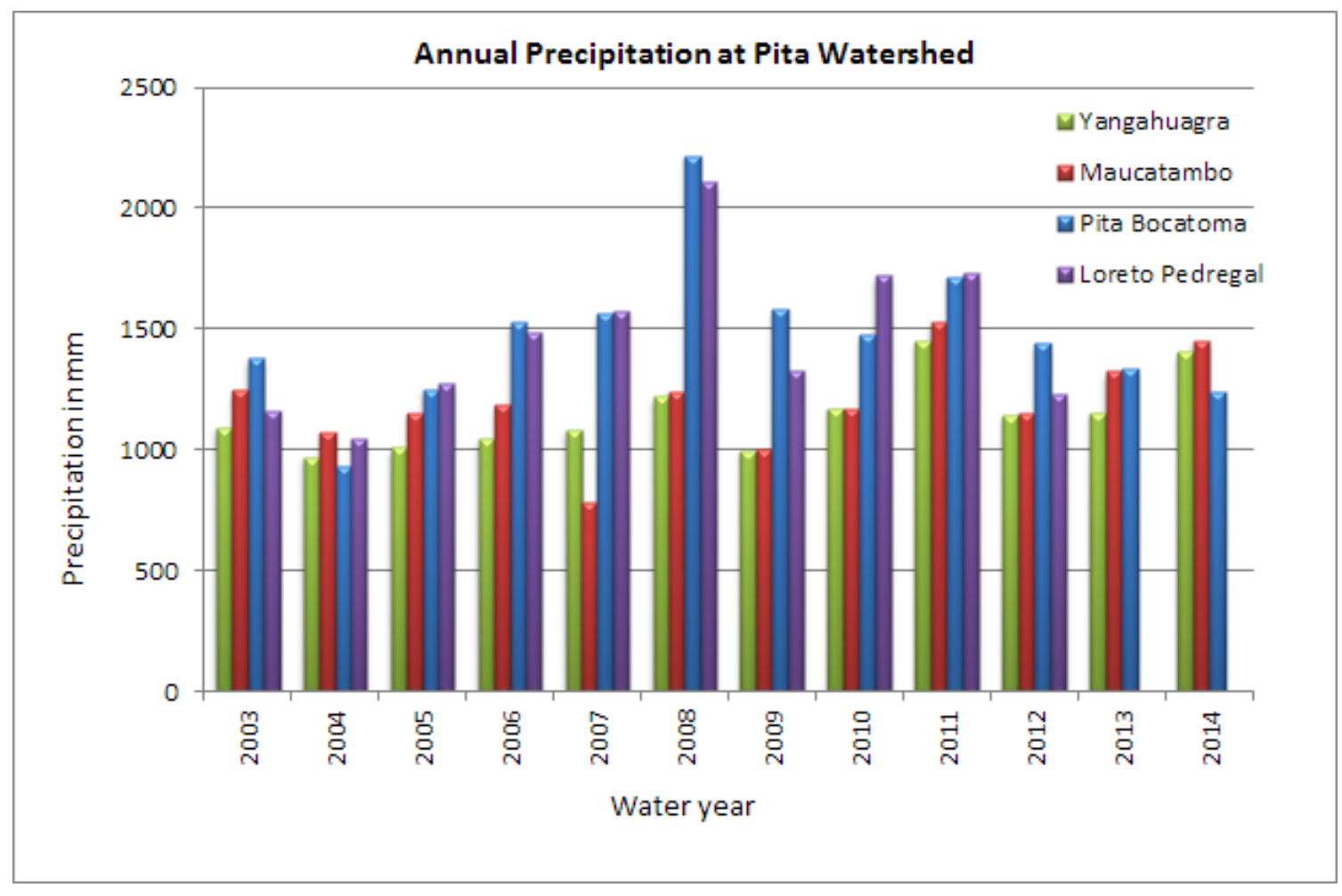

Figure 2.2 Annual precipitation at Pita watershed 


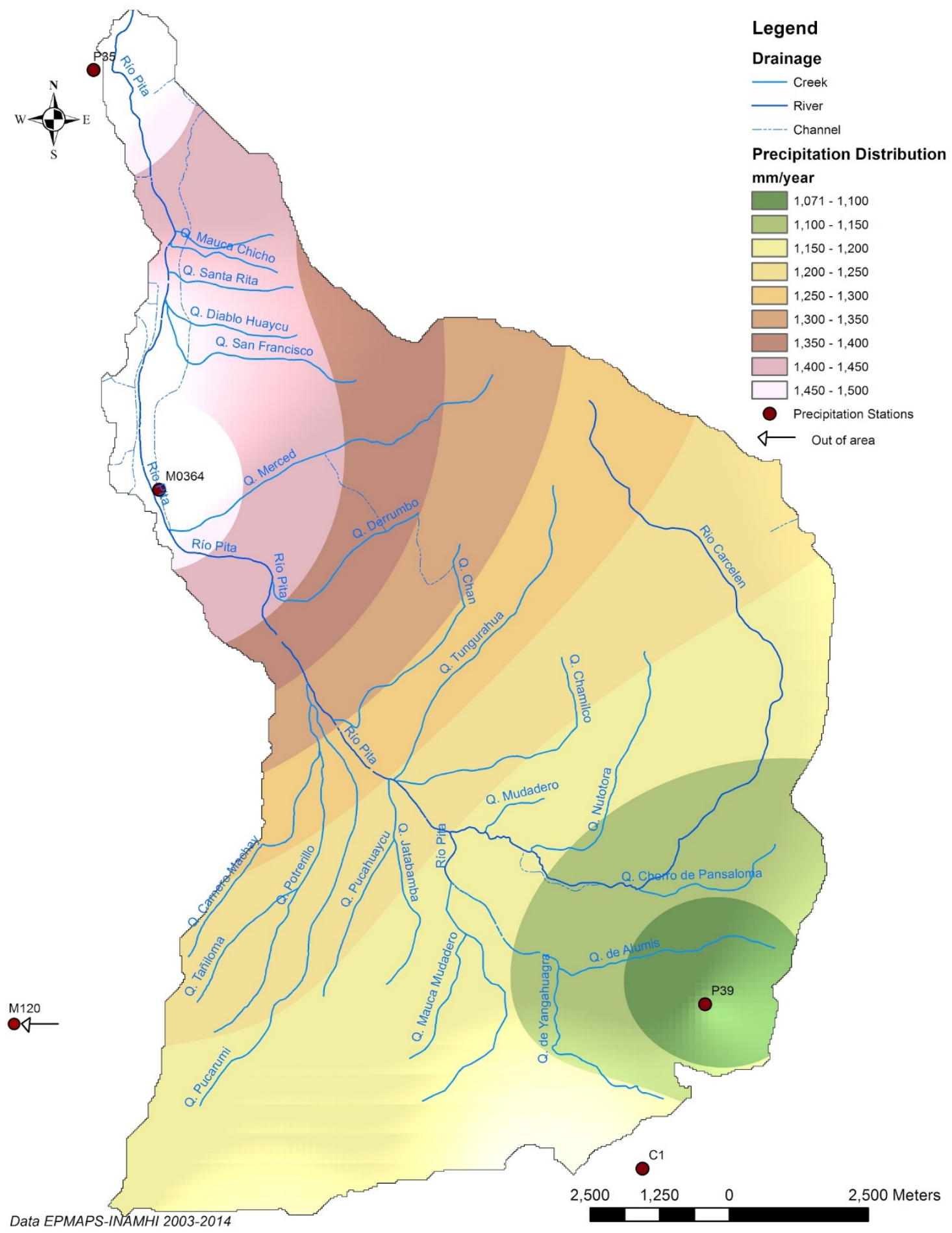

Figure 2.3 Isohyet map and hydrological stations in the study area (Map made for this work and data source from EPMAPS) 


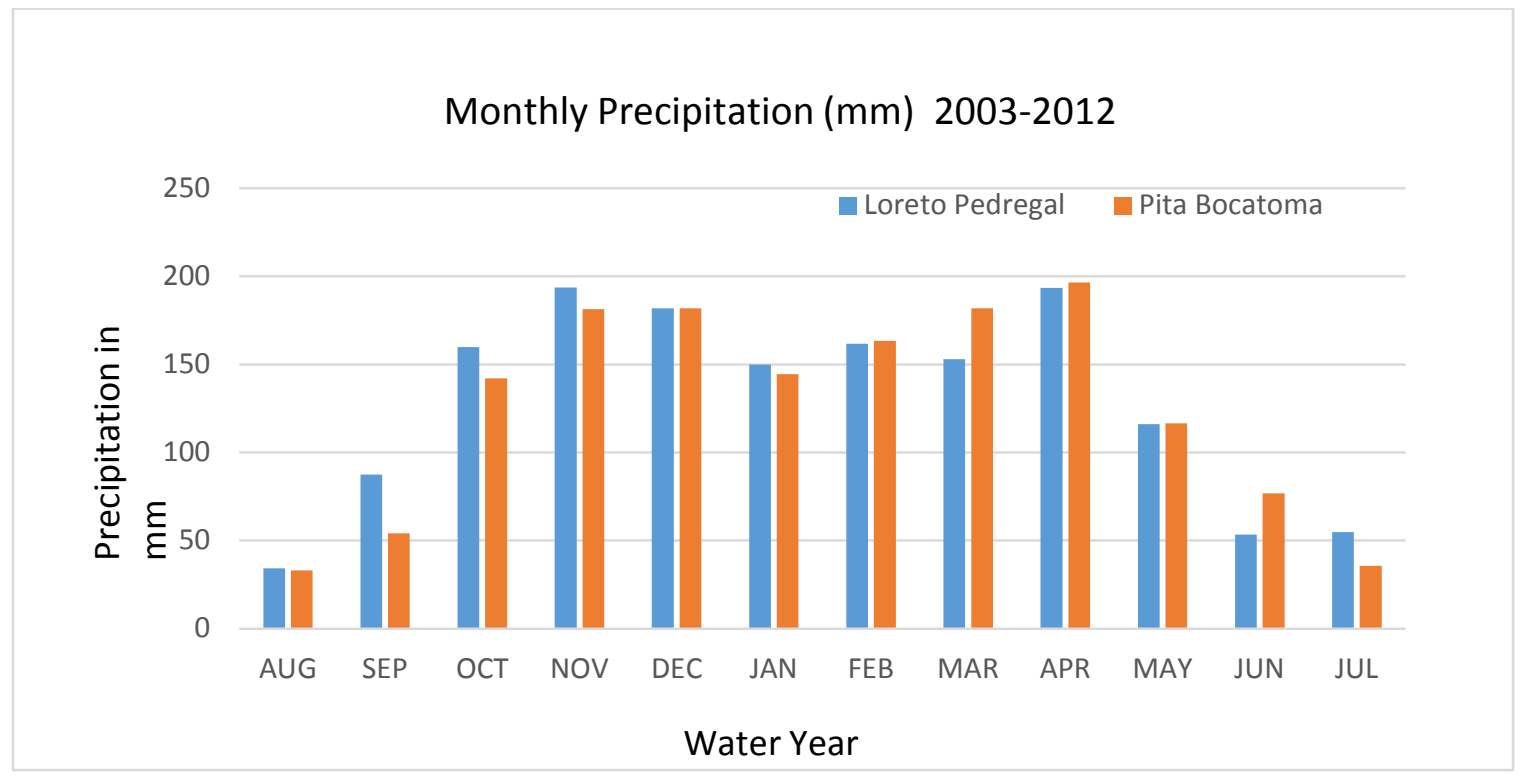

Figure: 2.4 Bimodal patterns at Center-North part of the watershed

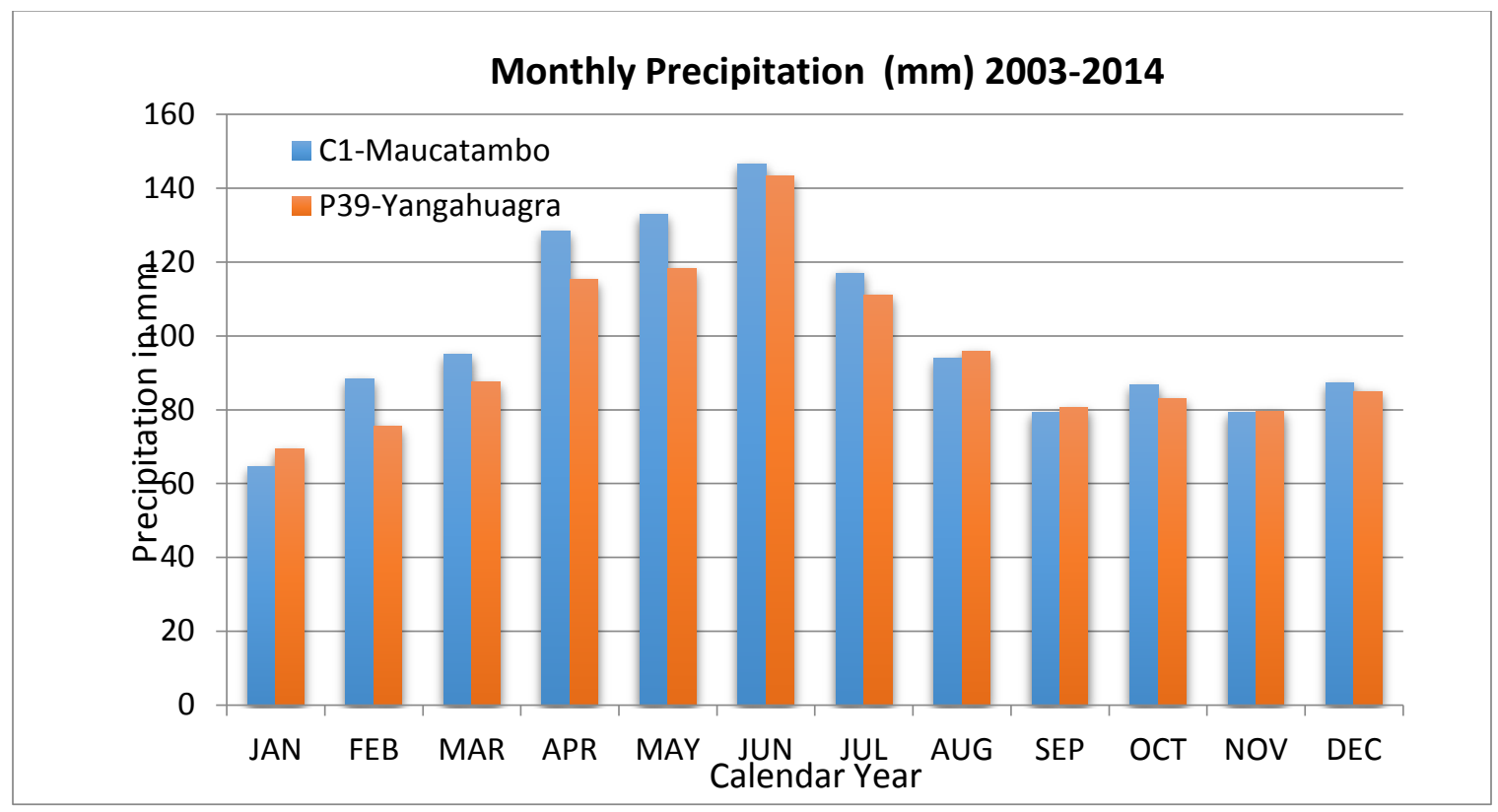

Figure 2.5 Modal pattern at eastern part of the watershed.

In order to understand this relationship, the hypsometric method was used which combines the distribution of elevation within a watershed with a known relationship between precipitation and elevation to determine weights for elevation classes using following linear equation 


$$
P_{g}=a z_{g}+b
$$

Where: $\quad P$ is the precipitation measured at gauge $\mathrm{g}$.

$\mathrm{z}$ is the elevation of gauge $\mathrm{g}$.

a can be considered a precipitation gradient $(\mathrm{dP} / \mathrm{dz})$ and is a fitting parameter $\mathrm{b}$ the curve fitting parameters.

In this method, the equation will replace the gauges and the distribution of the percentage areas will provide the weights.

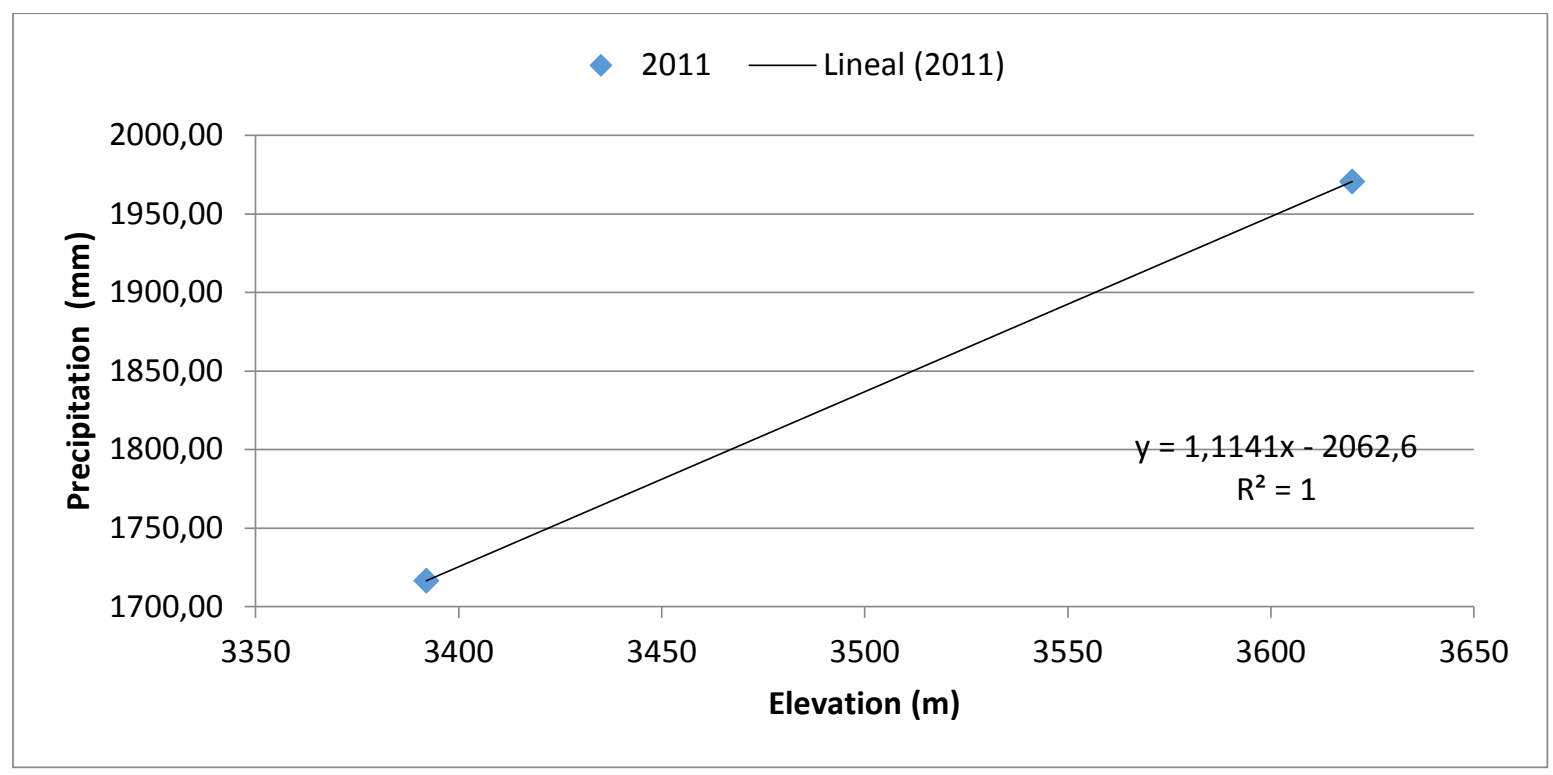

Figure 2.6 Relationship between total precipitation and elevation in 2011 across Pita Bocatoma and Loreto Pedregal stations. 


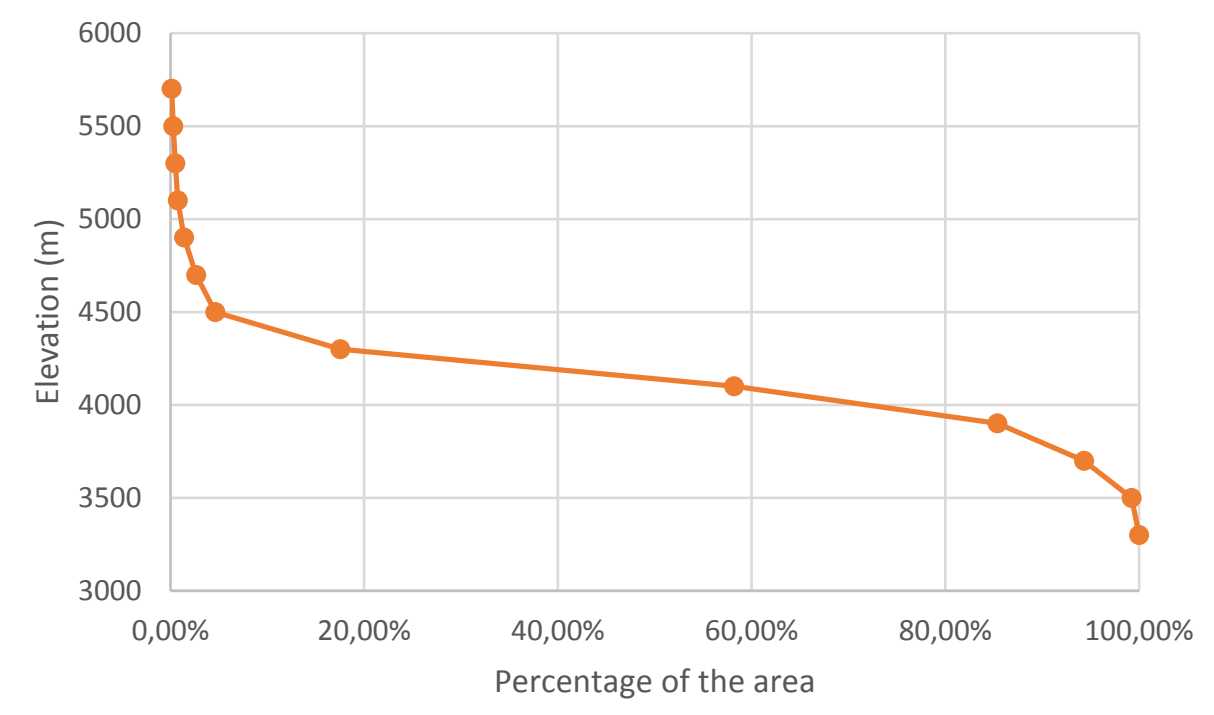

Figure 2.7 Upper Pita Watershed Hypsometric Function

After gathering precipitation totals for each gauge, the mathematical equation can be developed.

Table 2.3 Precipitation averages using hypsometric method.

\begin{tabular}{|c|c|r|r|r|}
\hline Year & $\begin{array}{c}\text { Pita } \\
\text { Bocatoma } \\
\text { Rain Gauge }\end{array}$ & $\begin{array}{c}\text { Loreto Pedregal } \\
\text { Rain Gauge }\end{array}$ & $\begin{array}{c}\text { Direct average } \\
\text { precipitation } \\
(\mathrm{mm})\end{array}$ & $\begin{array}{c}\text { Elevation } \\
\text { weighted } \\
\text { precipitation } \\
(\mathrm{mm})\end{array}$ \\
\hline 2010 & 1474.43 & 1720.30 & 1597.37 & 2168.80 \\
\hline 2011 & 1716.48 & 1970.50 & 1843.49 & 2426.21 \\
\hline 2012 & 1439.87 & 1590.93 & 1515.40 & 1852.09 \\
\hline 2013 & 1335.94 & 1539.80 & 1437.87 & 1889.53 \\
\hline
\end{tabular}

The results shows that the precipitation using hypsometric method is 1.3 higher than the direct average precipitation, this can be because there are only two gauge stations in the study area for the construction of the fitting curve.

\subsection{Temperature Analysis}

Temperatures are important in the estimation of evapotranspiration ET rates, as there are no ET-monitoring stations in the region. Based on daily data, average monthly and annual temperature was calculated for three stations located within the watershed or very close to 
it. The same methodology that was used for the precipitation analysis was used for the temperature analysis. The spatial distribution of annual temperature was calculated using the ArcGIS Spatial Analyst module, and the inverse distance weighted (IDW) was calculated using interpolation method. Station names, years of records and sources are indicated on Table 2.4. Location are indicated on Figures 2.1 and 2.8 showing the monthly average at these stations.

Table 2.4 Annual average temperature at Pita watershed

\begin{tabular}{|c|c|c|c|c|c|c|} 
Code & Name & $\begin{array}{c}\text { Easting } \\
(\mathbf{m})\end{array}$ & $\begin{array}{c}\text { Northing } \\
\mathbf{( m )}\end{array}$ & $\begin{array}{c}\text { Altitude } \\
\text { (masl) }\end{array}$ & Time Period & $\begin{array}{c}\text { Annual } \\
\text { Average } \\
\text { Temperature* } \\
\text { (mm) }\end{array}$ \\
\hline C11 & Pita Bocatoma & 785046 & 9945051 & 3360 & $2011-2015$ & 9.17 \\
\hline M120 & Cotopaxi-Clirsen & 769198 & 9931139 & 3510 & $2008-2013$ & 8.40 \\
\hline C1 & Maucatambo & 794900 & 9925334 & 3845 & $2007-2012$ & 5.60 \\
\hline \multicolumn{7}{|c|}{$*$ Annual average temperature values are monthly average } \\
\hline
\end{tabular}

12,00

10,00

Monthly Temperature ${ }^{\circ} \mathrm{C}$ at Pita Watershed

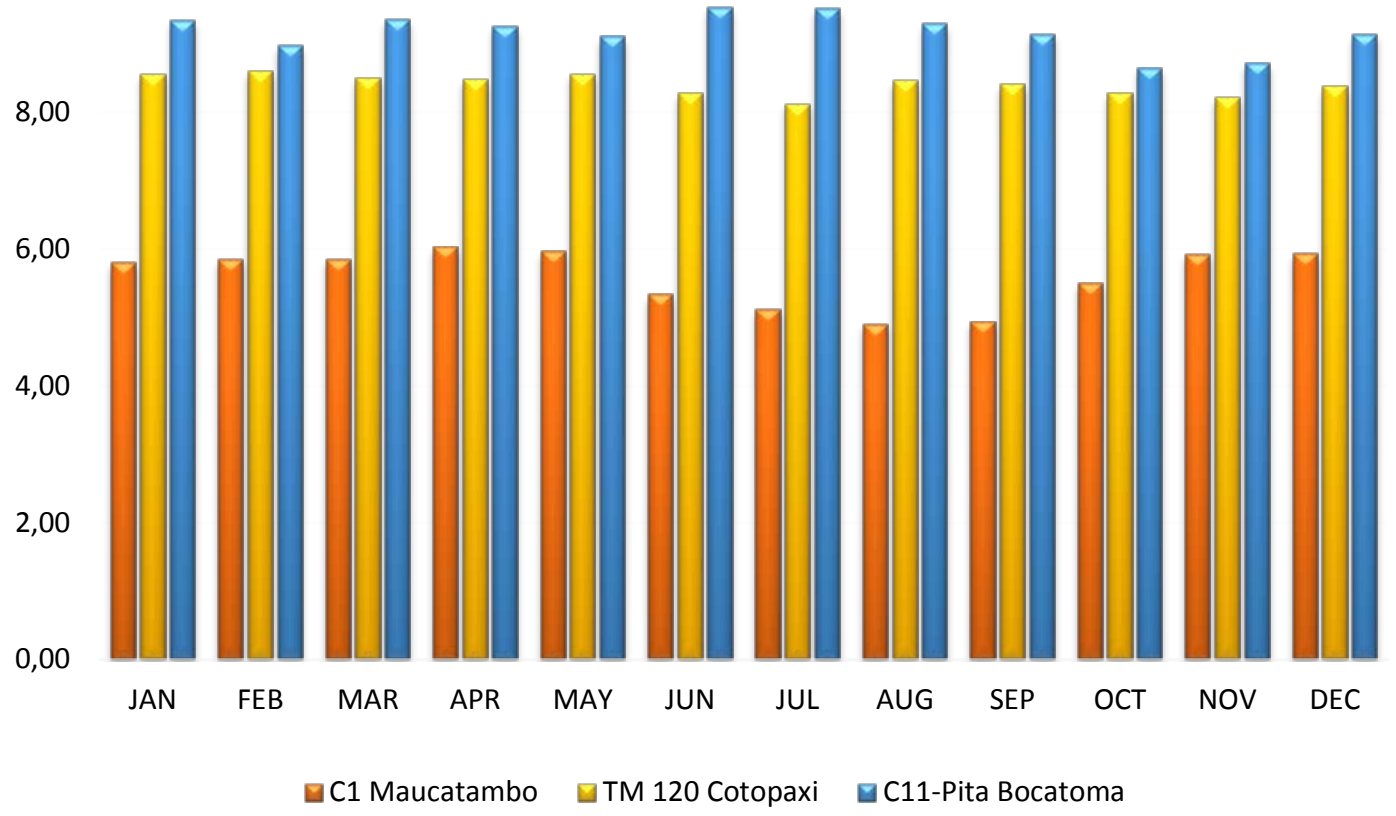

Figure 2.8 Monthly average temperature at Pita watershed 


\section{Results}

The results show that temperature in the study area ranges from 5.6 to $9.17{ }^{\circ} \mathrm{C}$ and that there is a direct relationship with the altitude as is shown in the isotherm map (Figure 2.9) and Table 2.5. Temperatures at the lower northern part of the watershed (Pita-Bocatoma) are more stable throughout the year whereas temperatures at the higher southern part of the watershed are more variable. 


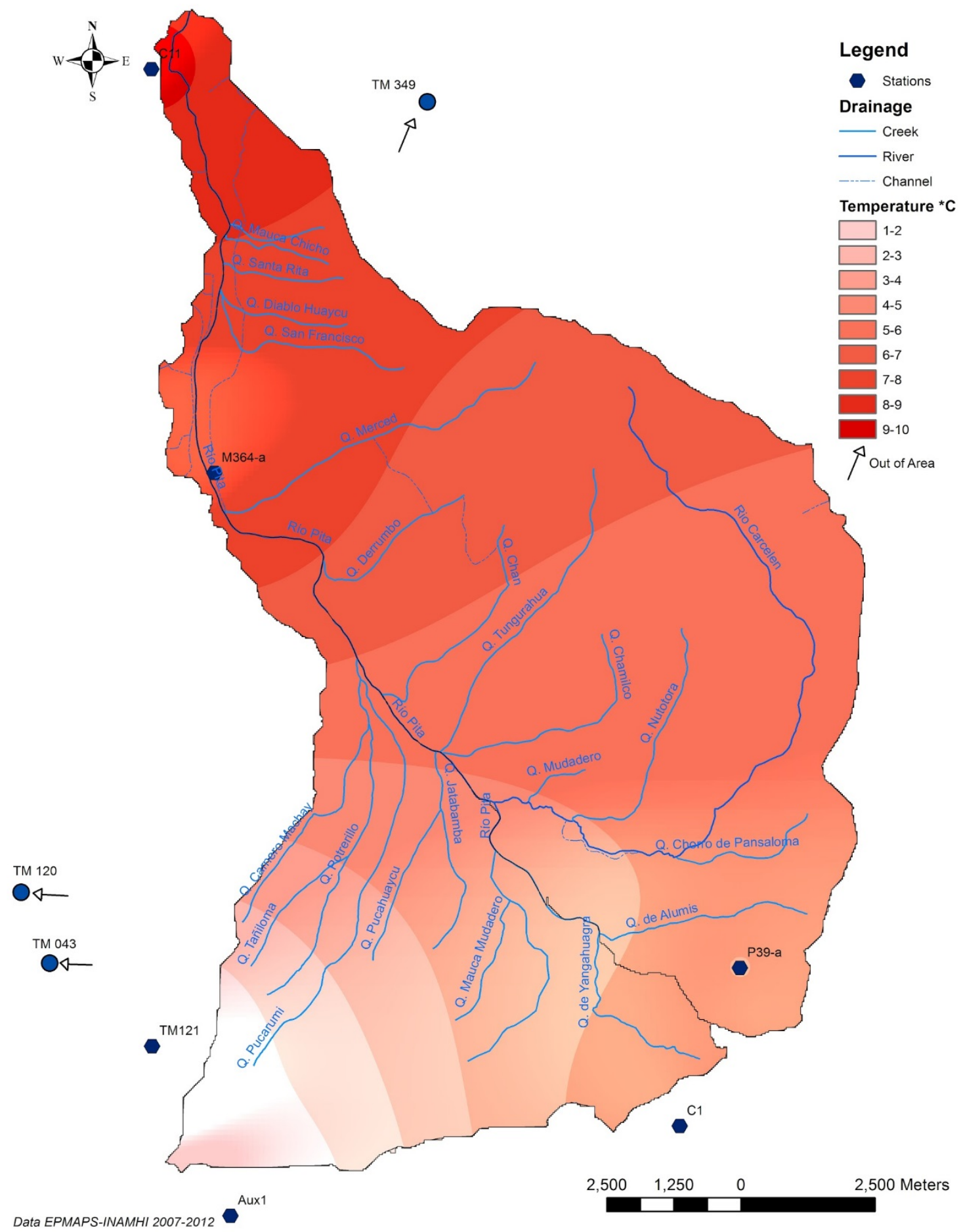

Figure 2.9 Isotherm map in Upper Pita Watershed (Source EPMAPS) 
Table 2.5 Monthly average temperature in ${ }^{\circ} \mathrm{C}$ (Source: $\mathrm{M}$ station belongs to INAMHI, C stations belong to EPMAPS).

\begin{tabular}{|c|c|c|c|c|c|c|c|c|c|c|c|c|}
\hline Code & Jan & Feb & Mar & Apr & May & Jun & Jul & Aug & Sep & Oct & Nov & Dec \\
\hline C11 & 9.3 & 9.0 & 9.4 & 9.3 & 9.1 & 9.5 & 9.5 & 9.3 & 9.1 & 8.6 & 8.7 & 9.1 \\
\hline TM 120 & 8.6 & 8.6 & 8.5 & 8.5 & 8.6 & 8.3 & 8.1 & 8.5 & 8.4 & 8.3 & 8.2 & 8.4 \\
\hline C1 & 5.8 & 5.9 & 5.9 & 6.0 & 6.0 & 5.3 & 5.1 & 4.9 & 4.9 & 5.5 & 5.9 & 5.9 \\
\hline
\end{tabular}

\subsection{Evapotranspiration}

Evapotranspiration is the combination of water evaporation from the surface, near-surface soils and transpiration by plants. In other words, the precipitation is intercepted and returned to the atmosphere by plants when there is no precipitation, plants and moisture wick to the surface by capillary action, to evapotranspire.

The predominantly andosolic soils present in the study area have porous structure, and a significant fraction of pore spaces are networks of small micropores that hold "inactive" water that is not flushed as infiltration (Buytaert et al., 2006). The paramo ecosystem is predominantly a cold and humid climate area with persistently low atmospheric pressure. The combination of soil and climate conditions favors the accumulation of the organic matter in the soils and creates conditions for high moisture-retention capacity (Buytaert et al., 2004). The cold, humid climatic conditions and relatively low-growth vegetation result in low potential evapotranspiration, although there is a dearth of evapotranspiration studies in the paramos (Buytaert et al., 2006).

Actual evapotranspiration (ET) is at most equal to PET but is less than PET much of the time in many areas. Actual evapotranspiration can reach the potential evapotranspiration when there is ample moisture available in the soils for the vegetation to transpire. According to Buytaert et al, (2004), paramo ecosystem has high regulation of water in soils. Although the amount of rainfall is not high at the paramo ecosystems, precipitation is frequent and this ecosystem is known to be very wet and cold, so the water availability is permanent the whole year, which can be recognized by the base flow on the rivers (Buytaert et al., 2006). Since PET is relatively low due to the low water consumption by vegetation and cold, humid conditions, the persistent water availability suggests that the assumption in this work that ET is always equal to PET is reasonable. This assumption is required because of the lack of ET-estimation tools for this kind of setting. See Buytaert et al. (2006) for more detailed insights and additional discussion.

For the estimation of the evapotranspiration, the precipitation data used here corresponds to the precipitation at Maucatambo and Pita Bocatoma stations, which represent the two elevation extremes of the watershed (Figure 2.4). The data series spans the calendar years 2007-2012. Because temperature shows little variation, monthly averages over the 2007- 
2012 period were used as mean monthly temperature for estimating potential evapotranspiration, as described below. Additionally, using the information from the landuse map, this watershed is $85 \%$ covered by paramo vegetation and pastures where root depth ranges from 0.5-1 m deep. The assumed soil- moisture (0.14) field capacity corresponds to a loamy sand (ASCE, 1990). Since both root-zone depth and field capacity were assumed and appear only as a product in the PET calculations, the combined product is the focus of sensitivity analysis.

\section{Methodology}

There are not methods for directly measuring evapotranspiration (ET) at a watershed scale. Watershed-scale studies involve a combination of theoretical and/or empirical methods coupled with water-budget analyses to estimate average or spatially distributed ET. Most empirical studies involve precipitation, temperature, land use, and solar radiation to estimate potential evapotranspiration (PET), which is the maximum value for evapotranspiration for an area. Assuming that in the area the PET is almost the same as ET for the climate conditions, this study used two empirically-based modeling approaches. The first approach (PET1) is from Thornthwaite (1948) and correlates ET to mean monthly temperature and the solar radiation. The general formula for Thornthwaite approach is:

$$
P E T=16 * K t(10 T / I) a
$$

Where $\quad \mathrm{T}=$ mean temperature for the month (in ${ }^{\circ} \mathrm{C}$ ),

$$
\begin{aligned}
& \mathrm{I}=\text { annual thermal index, }\left[\mathrm{i}=(\mathrm{T} / 5)^{1.514}\right], \\
& \mathrm{d}=\text { correction factor which depends on latitude and month, and a is }
\end{aligned}
$$$$
\mathrm{d}=0.49+0.0179 \mathrm{I}-0.0000771 \mathrm{I} 2+0.000000675 \mathrm{I} 3 .
$$

The second approach (PET2) uses the Thornthwaite-Type Monthly Water Balance (TMWB) Model (Dingman, 2002) to estimate ET. The calculations of the PET are based on mean daily temperature, saturation vapor pressure of the water and the day length

$$
P E T=29.8 D\left(\frac{\varrho a *(T a)}{T a+273.2}\right)
$$

where:

$$
\begin{aligned}
& \text { PET = estimated daily potential evapotranspiration }(\mathrm{mm} / \mathrm{d}) \text {, } \\
& \mathrm{D}=\text { day length }(\mathrm{hr}) \text {, } \\
& \mathrm{e}^{*} \mathrm{a}(\mathrm{Ta})=\text { saturation vapor pressure of water at } \mathrm{Ta}(\mathrm{kPa}) \text {, and } \\
& \mathrm{Ta}=\text { mean daily temperature }(\mathrm{oC}) \text {. }
\end{aligned}
$$

These approaches calculated PET from the Maucatambo and Pita Bocatoma data for each year, as well as the mean of the entire period. 


\section{Results}

The PET estimated using the Thornthewaite (1948) approach (PET1) is 43\% of the precipitation for Pita Bocatoma and $48 \%$ for Maucatambo analysis. Meanwhile, the TMWB-approach PET is 38\% of the precipitation for both sites. The results show that there are only small differences between the estimates from the two approaches (See Tables 2.6 and 2.7).

Table 2.6 PET using Thornthwaite general approach and Thornthwaite-Type Monthly water budget approach for Pita Bocatoma Site

\begin{tabular}{|l|c|c|c|c|c|}
\hline \multicolumn{7}{|c|}{ PITA BOCATOMA } \\
YEAR & P (mm) & $\begin{array}{c}\text { PET 1 } \\
\text { (mm) }\end{array}$ & $\%$ & $\begin{array}{c}\text { PET 2 } \\
(\mathbf{m m})\end{array}$ & $\%$ \\
\hline 2011 & 1716 & 618 & $36 \%$ & 542 & $32 \%$ \\
\hline 2012 & 1440 & 617 & $43 \%$ & 541 & $38 \%$ \\
\hline 2013 & 1336 & 625 & $47 \%$ & 554 & $41 \%$ \\
\hline 2014 & 1243 & 623 & $50 \%$ & 551 & $44 \%$ \\
\hline Mean & $\mathbf{1 4 3 4}$ & $\mathbf{6 2 1}$ & $\mathbf{4 3 \%}$ & $\mathbf{5 4 7}$ & $\mathbf{3 8 \%}$ \\
\hline \multicolumn{7}{|c|}{ P = Precipitation, } & PET=Potential Evapotranspiration \\
\hline
\end{tabular}

Table 2.7 PET using Thornthwaite general approach and Thornthwaite-Type Monthly water budget approach for Maucatambo Site.

\begin{tabular}{|l|l|l|l|l|l|}
\multicolumn{5}{|c|}{ MAUCATAMBO } \\
YEAR & P (mm) & $\begin{array}{l}\text { PET } \\
(\mathbf{m m})\end{array}$ & $\mathbf{1} \%$ & $\begin{array}{l}\text { PET } \\
\mathbf{( m m})\end{array}$ & $\mathbf{2}$ \\
\hline 2007 & 786 & 550 & $67 \%$ & 431 & $55 \%$ \\
\hline 2008 & 1242 & 552 & $44 \%$ & 425 & $34 \%$ \\
\hline 2009 & 1000. & 554 & $55 \%$ & 435 & $44 \%$ \\
\hline 2010 & 1166 & 557 & $48 \%$ & 442 & $38 \%$ \\
\hline 2011 & 1528 & 554 & $36 \%$ & 436 & $29 \%$ \\
\hline 2012 & 1151 & 554 & $48 \%$ & 434 & $38 \%$ \\
\hline Mean & $\mathbf{1 1 4 6}$ & $\mathbf{5 5 4}$ & $\mathbf{4 8 \%}$ & $\mathbf{4 3 4}$ & $\mathbf{3 8 \%}$ \\
& & P = Precipitation, PET=Potential Evapotranspiration \\
\hline
\end{tabular}




\subsection{Runoff}

Due to EPMAPS using water from different watersheds and their mandate to monitor the quantity and quality of it, the discharge data available is relatively detailed in those sites where they have civil infrastructure. This is the case for Pita System that involves the stations shown in Table 2.8. Fig. 2.1 shows the location of those water stations. Daily discharge (in $\mathrm{m}^{3} / \mathrm{s}$ ) data is available for a period spanning from 2003 to 2014 for the EPMAPS stations. Considering that H12-Bocatoma is the lowest station in the watershed, it is considered as the point that receives all the watershed discharge with an annual average of $2.5 \mathrm{~m}^{3} / \mathrm{s}$ (See Table 2.9).

Table 2.8 Discharge monitoring stations for Pita System -EPMAPS

\begin{tabular}{|l|l|c|c|c|}
\hline Code & Name & Easting & $\begin{array}{c}\text { Northing } \\
(\mathbf{m})\end{array}$ & Altitude \\
\hline H12 & Pita Bocatoma & 786020 & 9944635 & 3430 \\
\hline H158 & Pita AJ Salto & 786727 & 9936823 & 3550 \\
\hline PT16 & Río Pita campamento Proaño & 786150 & 9937359 & 3631 \\
\hline PT04 & Rio Pita sitio Salitre & 788508 & 9934669 & 3748 \\
\hline PT02 & Rio Pita AJ Mudadero & 791455 & 9931406 & 3879 \\
\hline PT03 & Rio Mudadero AJ Río Pita & 791430 & 9931378 & 3879 \\
\hline
\end{tabular}

Table 2.9 Monthly average of discharge $\left(\mathrm{m}^{3} / \mathrm{s}\right)$ in the Upper Pita Watershed

\begin{tabular}{|c|c|c|c|c|c|}
\hline Year & \multicolumn{1}{c}{ H12 } & \multicolumn{1}{c}{ PT 16 } & \multicolumn{1}{c}{ PT04 } & PT02 & PT03 \\
\hline 2003 & 2.17 & 1.98 & 1.90 & 0.75 & 0.58 \\
\hline 2004 & 1.98 & 1.86 & 1.97 & 0.56 & 0.41 \\
\hline 2005 & 2.11 & 1.99 & 1.76 & 0.56 & 0.39 \\
\hline 2006 & 2.54 & 2.45 & 2.11 & 0.63 & 0.58 \\
\hline 2007 & 2.47 & 2.42 & 1.90 & 0.62 & 0.54 \\
\hline 2008 & 3.42 & 3.23 & 3.03 & 1.00 & 0.94 \\
\hline 2009 & 2.21 & 2.41 & 2.11 & 0.64 & 0.54 \\
\hline 2010 & 2.29 & 3.05 & 1.82 & 0.66 & 0.68 \\
\hline 2011 & 3.88 & 3.12 & 2.75 & 0.83 & 0.91 \\
\hline 2012 & 2.37 & 1.90 & 3.29 & 0.85 & 0.88 \\
\hline
\end{tabular}




\begin{tabular}{|c|c|c|c|c|c|}
\hline Year & \multicolumn{1}{c}{ H12 } & \multicolumn{1}{c}{ PT 16 } & PT04 & PT02 & PT03 \\
\hline 2013 & 1.65 & 1.92 & 1.58 & 0.52 & 0.42 \\
\hline 2014 & 2.76 & 2.23 & 2.06 & 0.57 & 0.62 \\
\hline Average & 2.49 & 2.38 & 2.19 & 0.68 & 0.62 \\
\hline Min & 1.65 & 1.86 & 1.58 & 0.52 & 0.39 \\
\hline Max & 3.88 & 3.23 & 3.29 & 1.00 & 0.94 \\
\hline SD & 0.62 & 0.45 & 0.52 & 0.14 & 0.19 \\
\hline
\end{tabular}

\section{Methodology}

EPMAPS obtains the discharge values through manual measurements in different gauging stations, and is recorded into a MS-Access database. Hydrologist analyze this data to compute average monthly discharge at Bocatoma station and average annual discharge in the entire watershed. The observed discharge are compared to observations of precipitation and temperature in Figure 2.10

\section{Results and conclusion}

Not surprisingly, discharge variations are very similar to precipitation variations. This likely means that most of the contributions of the river flow comes from rain. It could also mean that the contribution from glacier melting water is small. This uncertainty deems it necessary to use another technique to elucidate the glacier meltwater contributions.

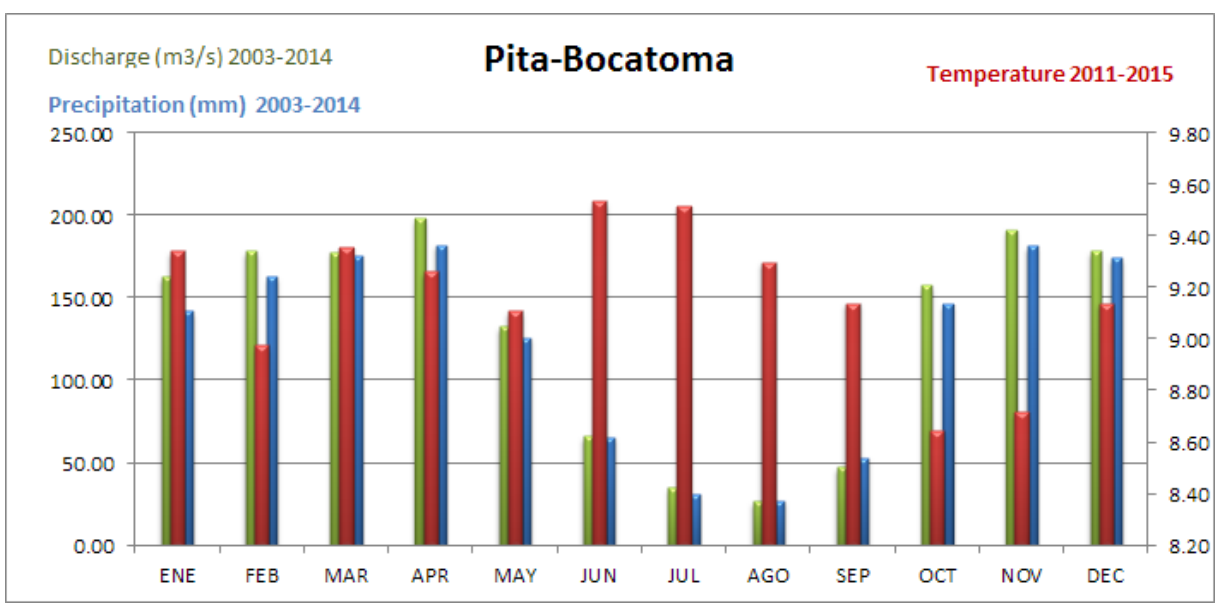

Figure 2.10 Precipitation, Discharge and Temperature at Pita Bocatoma 


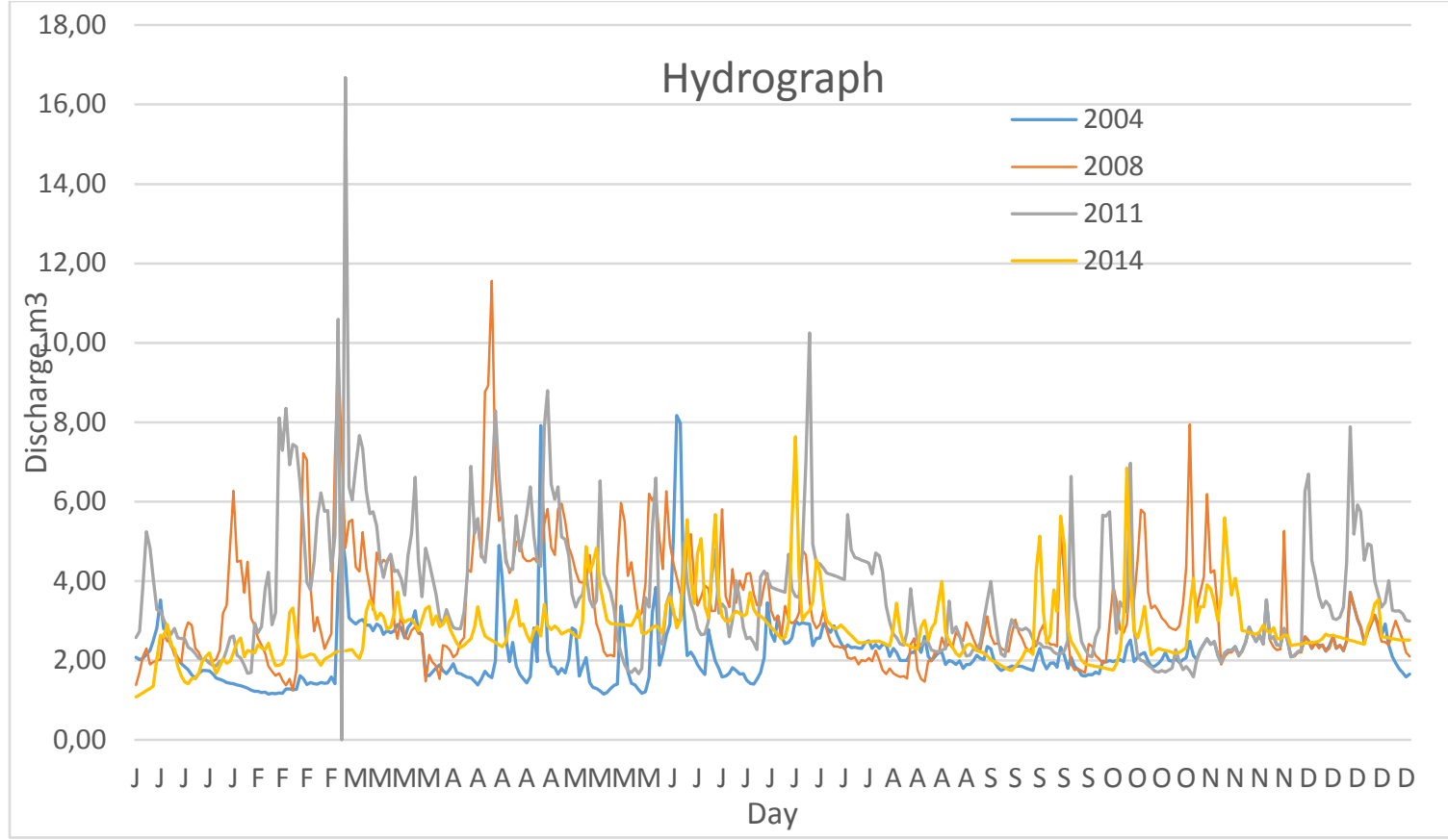

Figure 2.11 Discharge at Pita Bocatoma considering the wettest (2008-2011) and driest years (2004-2014)

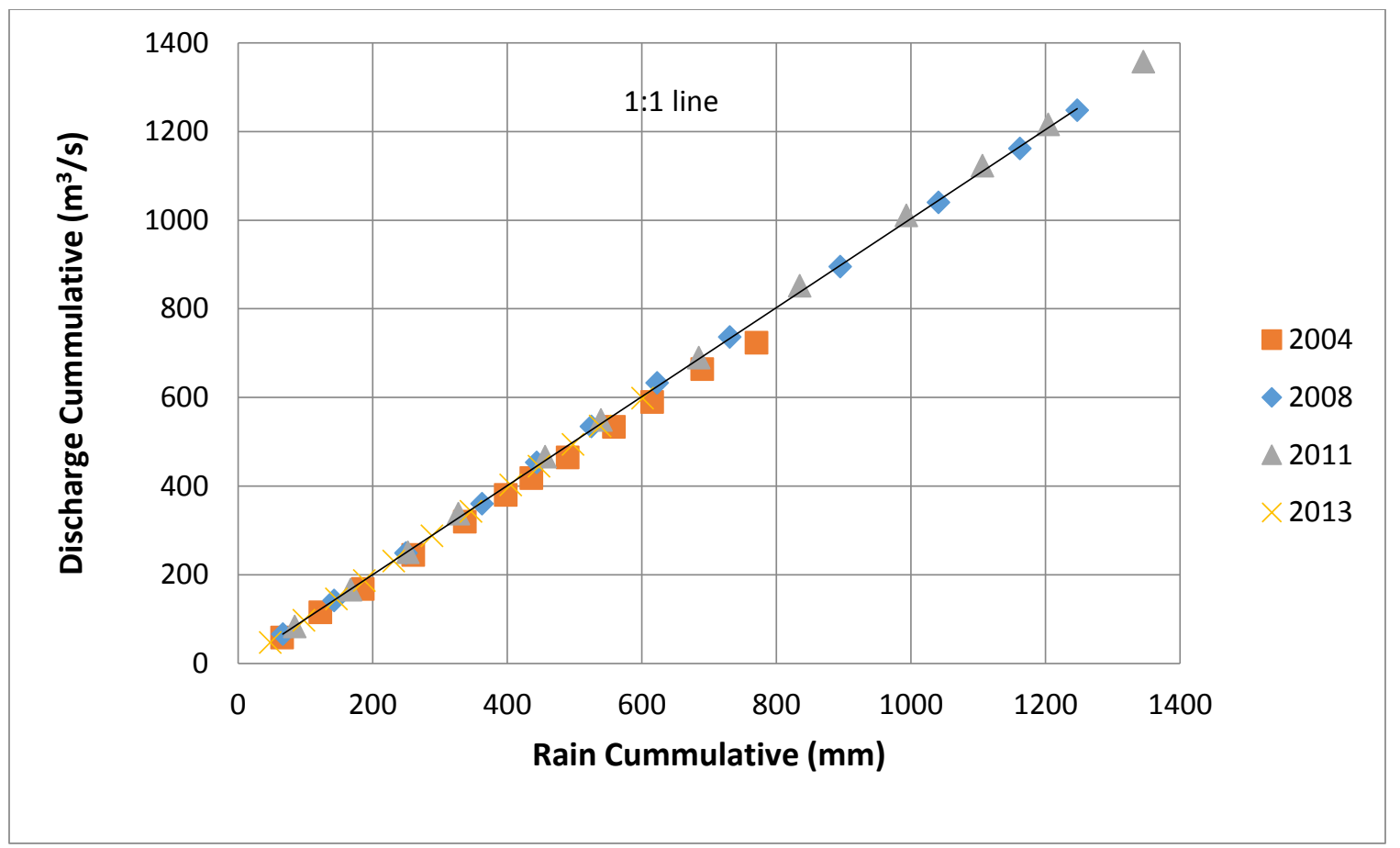

Figure 2.12 Relationship between Accumulated discharge and accumulated precipitation at Pita Bocatoma (Data source EPMAPS) 


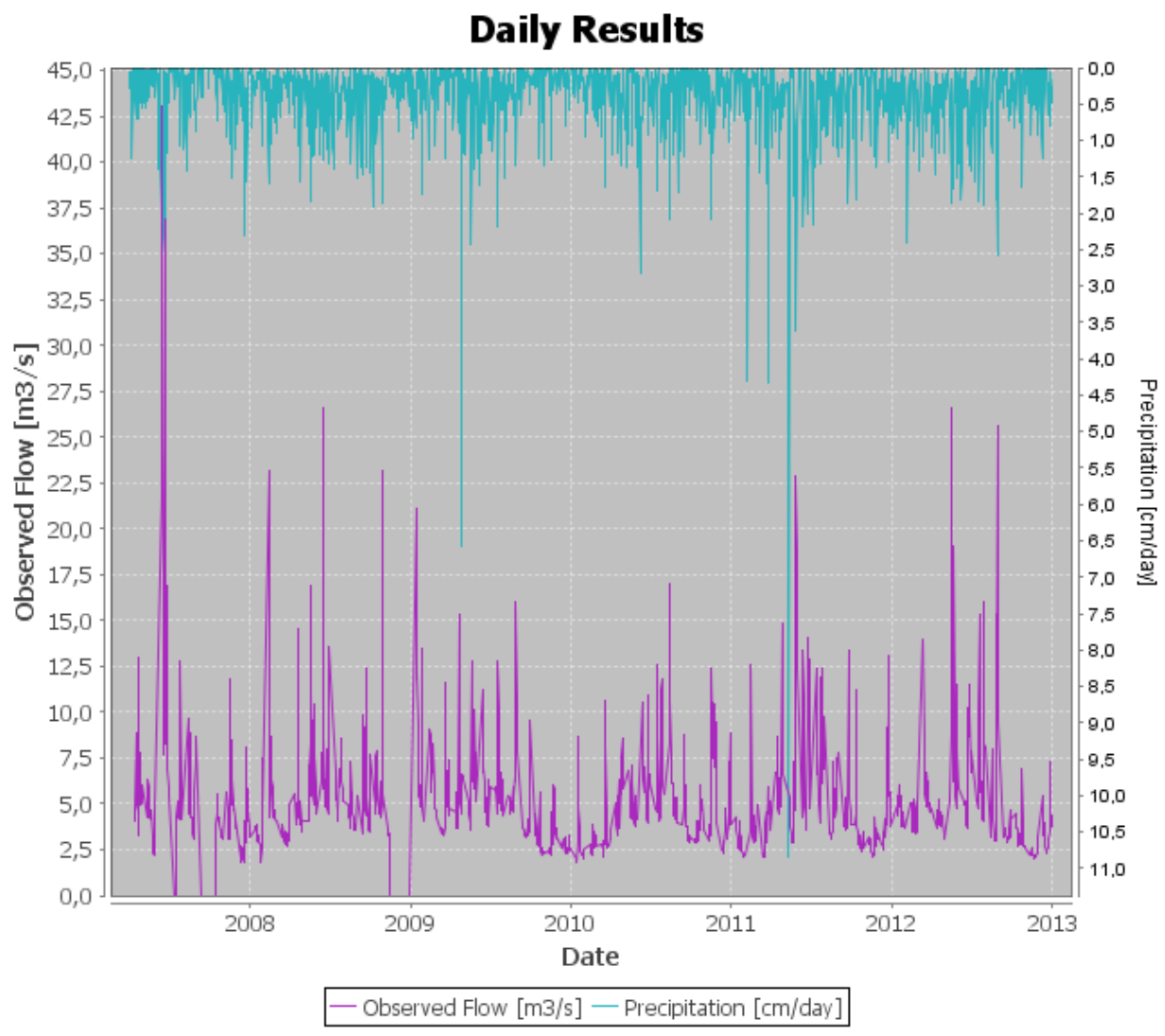

Figure 2.13 Relationship between discharge and precipitation at Pita Bocatoma from 2008-2013 (Data source EPMAPS using HydroBID Program)

Data from 2011-2014 were used to calculate the runoff in the watershed due to the consistent evapotranspiration calculations at the Pita Bocatoma site given that it covers almost all of the watershed (Table 2.10).

Table 2.10 Discharge at Pita Bocatoma $\mathrm{H12}$ in $\mathrm{m}^{3} / \mathrm{s}$ and $\mathrm{mm} / \mathrm{yr}$. (Values considered as runoff for the area)

\begin{tabular}{|c|c|c|}
\hline Year & $\begin{array}{c}\text { Discharge } \\
\mathrm{m}^{3} / \mathrm{s}\end{array}$ & $\begin{array}{l}\text { Discharge } \\
\text { mm/year }\end{array}$ \\
\hline 2011 & 3.88 & 714.72 \\
\hline 2012 & 2.37 & 436.57 \\
\hline 2013 & 1.65 & 303.94 \\
\hline 2014 & 2.76 & 508.41 \\
\hline
\end{tabular}




\section{Watershed delineation}

The watershed was delineated using the Arc Hydro GIS tool in ArcGis 10.2.2 specifically. It uses a methodology based on the analysis of the DEM and stream-course delineation. Areas of contribution (watersheds) for each discharge station were computed. Observed mean flows for the period of record are listed in Table 2.10 relative to the areas of contribution. The unit area discharge is computed as mean discharge divided by the contributing drainage area and it is expressed in the same units of measurement as precipitation, $\mathrm{mm} / \mathrm{year}$

\section{Results and conclusion}

Table 2.11 Contribution areas and discharge

\begin{tabular}{|c|c|c|c|c|c|}
\hline Code & Station & $\begin{array}{l}\text { Area } \\
(\mathrm{Km} 2)\end{array}$ & $\begin{array}{c}\text { Discharge } \\
\text { (m3/s) }\end{array}$ & $\begin{array}{l}\text { Discharge } \\
\text { (mm/year) }\end{array}$ & $\begin{array}{c}q \\
(1 / s / k m 2)\end{array}$ \\
\hline PT02 & Pita AJ Mudadero & 34 & 0.67 & 631 & 20 \\
\hline PT03 & Mudadero AJ Pita & 44 & 0.61 & 440 & 14 \\
\hline PT04 & Pita Salitre (Guitig)* & 128 & 2.47 & 607 & 19 \\
\hline PT16 & Pita Proano (Patichubamba)* & 149 & 2.78 & 590 & 19 \\
\hline $\mathrm{H} 12$ & Pita Bocatoma (Patichubamba)* & 171 & 2.84 & 523 & 17 \\
\hline
\end{tabular}

Discharge including external concession values Guitig 0.25 and Patichibamba $0.1 \mathrm{l} / \mathrm{s}$

At the intersection of the Mudadero and Pita rivers, there are two hydrological stations PT02 and PT03. In the case of the contribution area at PT02, it corresponds entirely to the Cotopaxi volcano contribution, whereas at PT03 all the contribution area is from the Sincholagua volcano. At that intersection, the Cotopaxi contribution represents $44 \%$ and Sincholagua contribution represents 56\%. The unit area discharge at Cotopaxi contribution is $20 \mathrm{l} / \mathrm{s} / \mathrm{km}^{2}$ while the unit area discharge at Sincholagua contribution is $14.05 \mathrm{l} / \mathrm{s} / \mathrm{km}^{2}$. (Figure 2.14.)

At Pita Salitre station (PT04), the contribution area is around $128 \mathrm{~km}^{2}$ and the unit area discharge is $19.26 \mathrm{l} / \mathrm{s} / \mathrm{km}^{2}$. The contribution area of Cotopaxi volcano corresponds to $47 \%$ of the entire area and $53 \%$ of the entire area corresponds to the Sincholagua contribution. In terms of discharge, 1.14 to $2.45 \mathrm{~m}^{3} / \mathrm{s}$ comes from Cotopaxi volcano (Figure 2.15).

At Pita Proano station, (PT16) the contribution area is $148.5 \mathrm{~km}^{2}$, and the unit area discharge is $18.72 \mathrm{l} / \mathrm{s} / \mathrm{km}^{2}$. The contribution area from Cotopaxi Volcano corresponds to $43 \%$ of the whole area and $57 \%$ of the total area corresponds to Sincholagua volcano contribution. In terms of discharge, 1.18 to $2.78 \mathrm{~m}^{3} / \mathrm{s}$ comes from Cotopaxi volcano (Figure 2.16).

At Pita Bocatoma station, (H12) the contribution area is $171 \mathrm{~km}^{2}$ and the unit area discharge is $16.89 \mathrm{l} / \mathrm{s} / \mathrm{km}^{2}$. The contribution area from Cotopaxi Volcano corresponds to $33 \%$ of the 
whole area and $67 \%$ of the total area corresponds to Sincholagua volcano contribution. In terms of discharge, 0.95 to $2.89 \mathrm{~m}^{3} / \mathrm{s}$ come from Cotopaxi volcano (Figure 2.16). The summary of all these areas is presented in Table 2.11.

Based on 12 years of daily discharge data from EPMAPS at all the gaging stations, the runoff is reported as discharge/area, I obtained the regression line that shows slope that represents the runoff, and it is reported as discharge/area. This value is $17.9 \mathrm{l} / \mathrm{s} / \mathrm{km}^{2}$ when compared with the average data is $17.78 \mathrm{l} / \mathrm{s} / \mathrm{km}^{2}$. (Figure. 2.17.)

The average of the runoff, A(P-ET), calculated for this analysis is $564.5 \mathrm{~mm} /$ year, which represents 38\% of the precipitation (1471.7 mm) at Pita Bocatoma from 2007-2012. 184.7 $\mathrm{mm}$ /year comes from Cotopaxi volcano.

According to the relationship between area and discharge for the entire upper Pita watershed $\left(173 \mathrm{~km}^{2}\right)$, the discharge corresponds to $3.1 \mathrm{~m}^{3} / \mathrm{s}$. (571 mm/yr). 


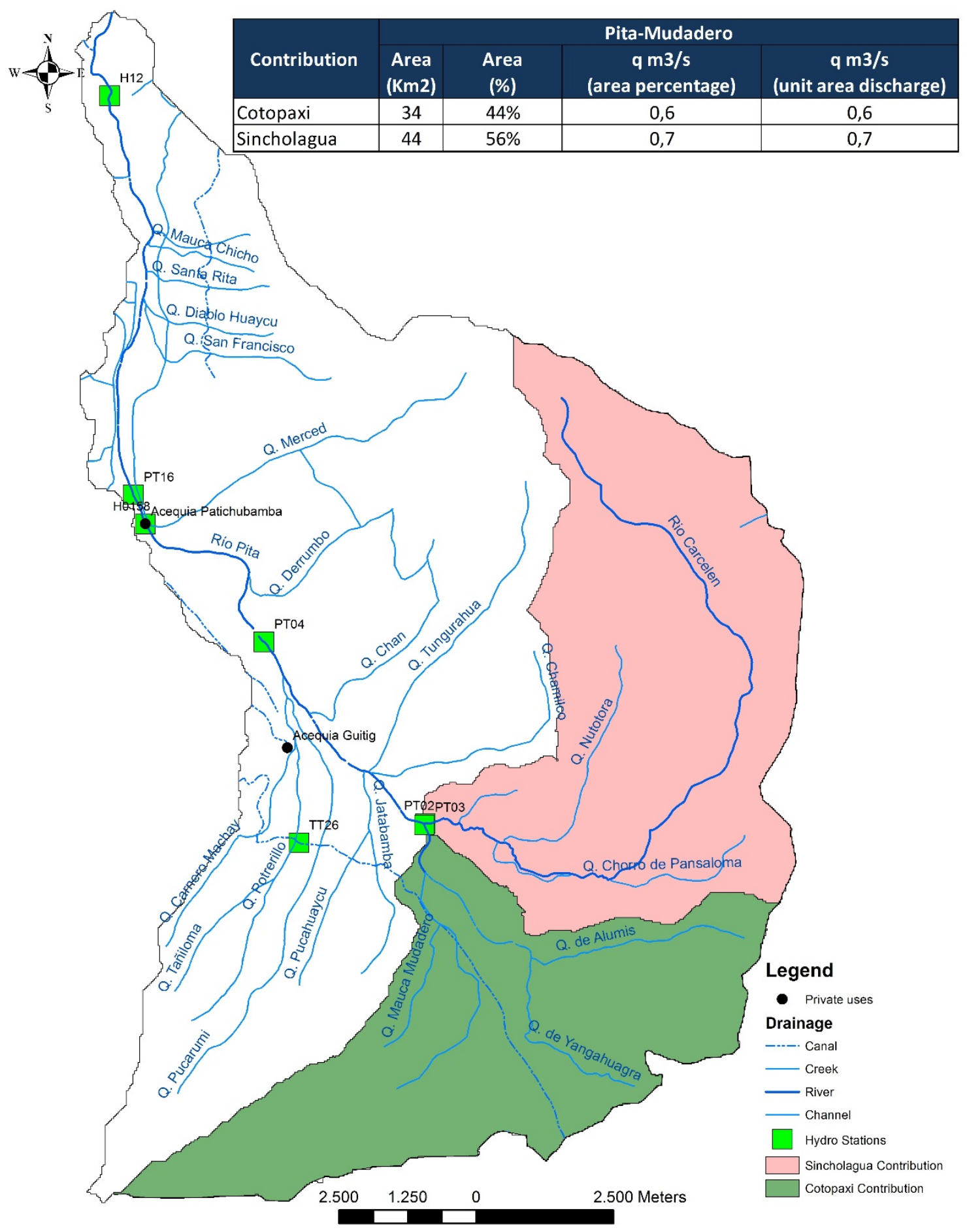

Figure 2.14 Contribution Areas for PT02 Pita AJ Mudadero and PT03 Mudadero AJ Pita 


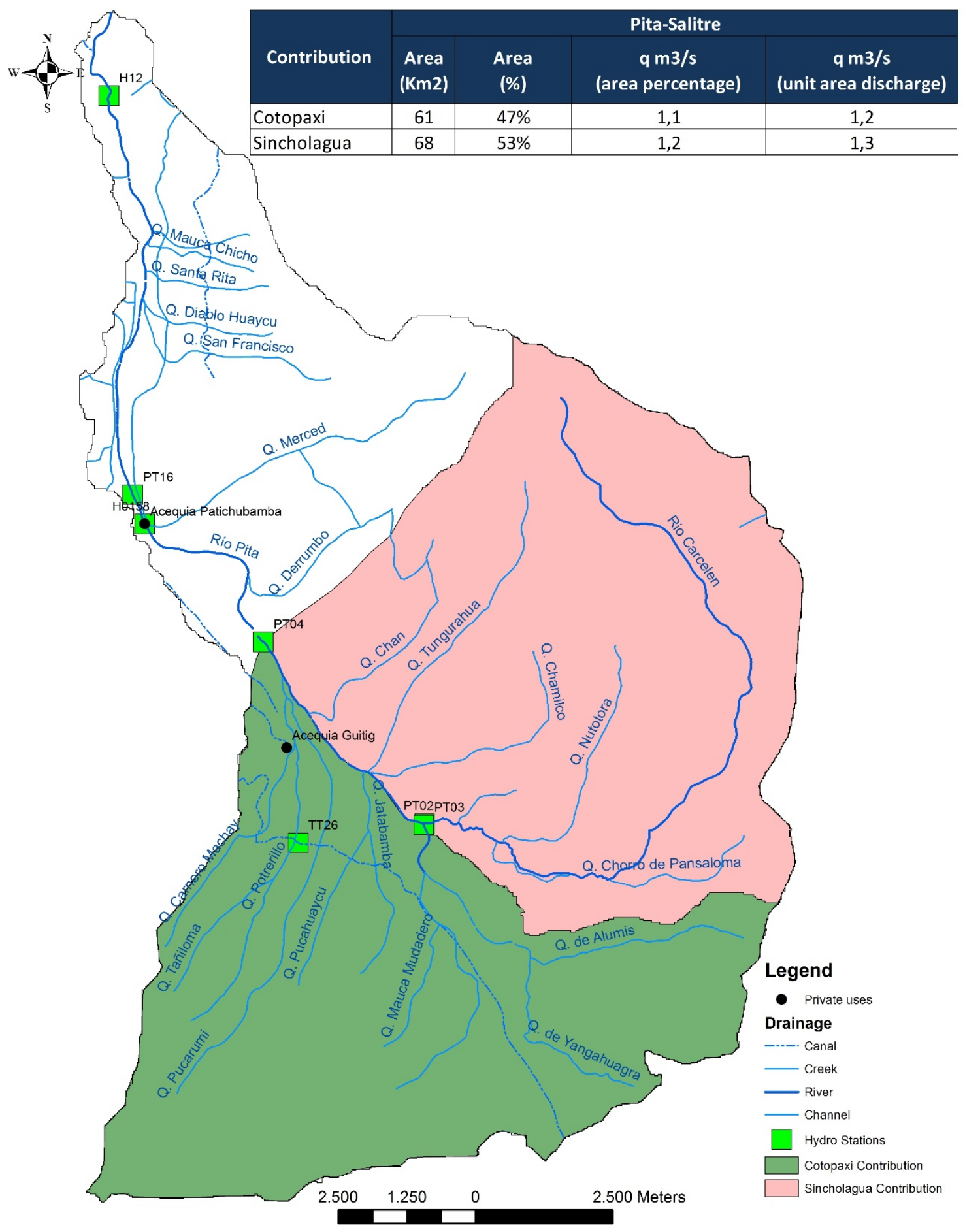

Figure 2.15 Contribution areas for PT04 Salitre 


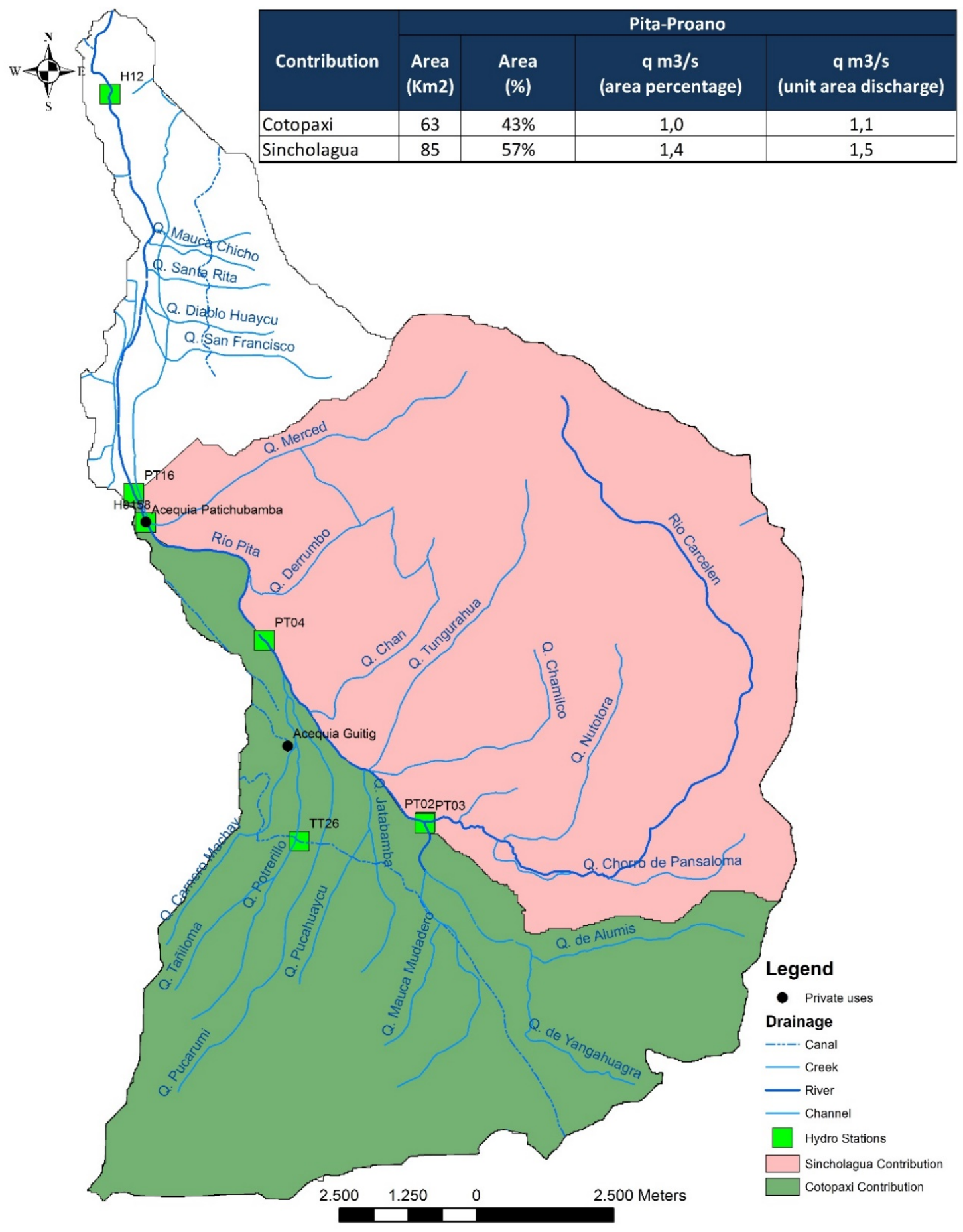

Figure 2.16 Contribution areas for PT 16 Proano 


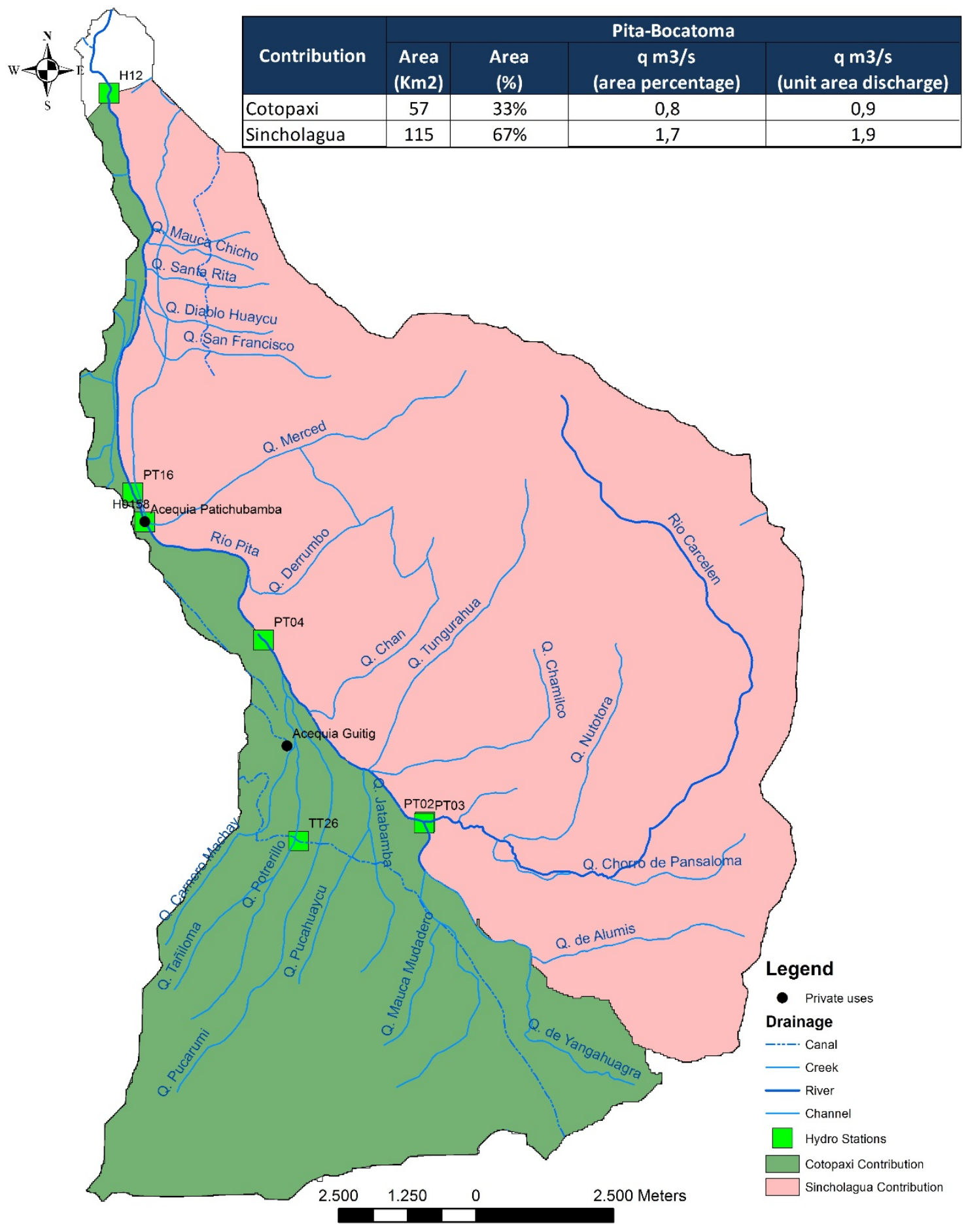

Figure 2.17 Contribution areas for H12-Bocatoma 


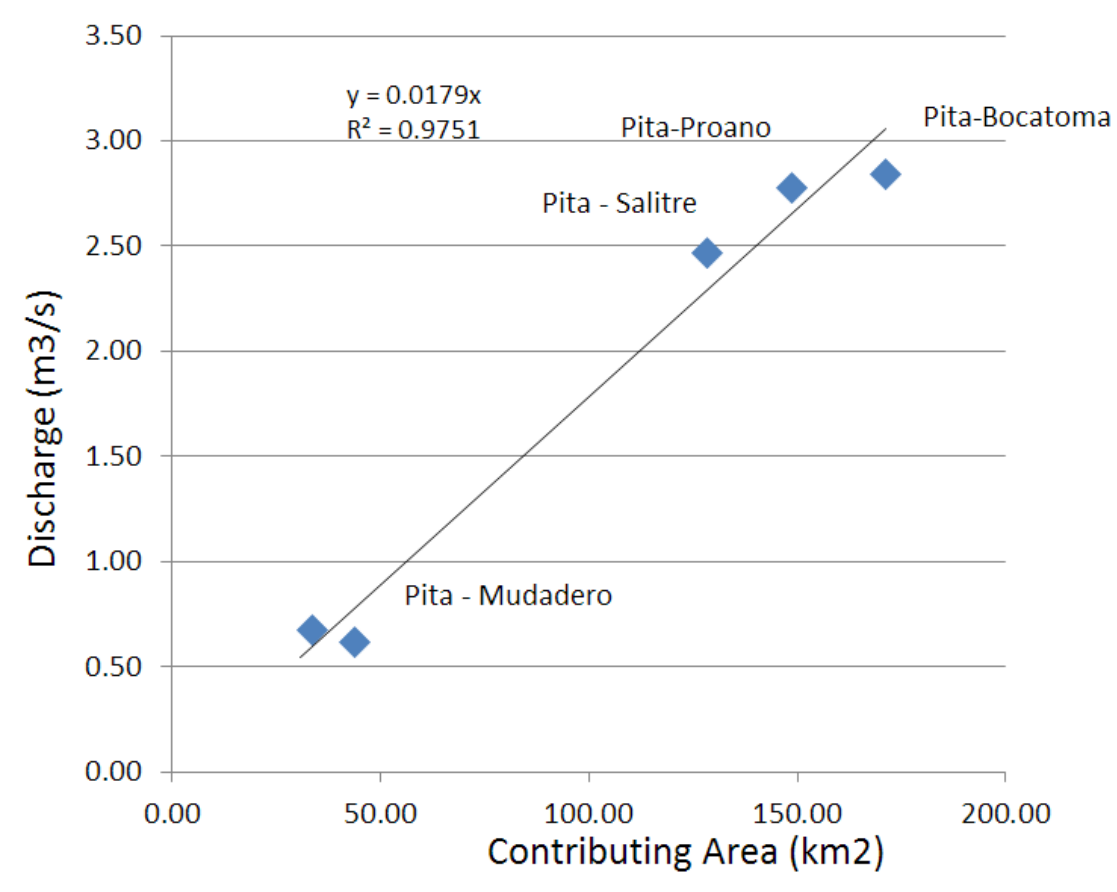

Figure 2.18 Average annual river discharge for Pita watershed based on 12 years of daily discharge data from EPMAPS. Gauging Stations. Runoff is reported as discharge/area. 


\section{SECTION III WATER BUDGET AND SOURCES OF CONTRIBUTION}

\subsection{Water Budget}

The water demand for human consumption and for agriculture near Pita river basin populations is one of the factors that make it necessary to know the availability of water in the basin. Water availability is influenced not only by natural hydrologic cycle processes that involve precipitation, but also by social, economic and legal factors. To manage water supplies effectively, it is important to first know the availability of the water resource through a quantitative approach using a water budget analysis.

The water budget on this watershed scale was calculated using the follow expression:

$$
P=E T+R O+R C H G
$$

where:

$$
\begin{array}{ll}
P & =\text { precipitation, } \\
E T \quad=\text { evapotranspiration, } \\
R O \quad=\text { runoff, } \\
R C H G=\text { groundwater or subsurface flux }
\end{array}
$$

\begin{tabular}{|c|c|c|c|c|}
\hline & $\begin{array}{c}P \\
(\mathrm{~mm} / \mathrm{yr})\end{array}$ & $\begin{array}{l}\text { PET (0.38P) } \\
(\mathrm{mm} / \mathrm{yr})\end{array}$ & $\begin{array}{c}\text { RO+RCHG (0.38P) } \\
(\mathrm{mm} / \mathrm{yr})\end{array}$ & $\begin{array}{c}\text { DIFF(0.24P) } \\
(\mathrm{mm} / \mathrm{yr})\end{array}$ \\
\hline Median & 1330 & 505 & 505 & 319 \\
\hline Min & 1144 & 435 & 435 & 275 \\
\hline Max & 1472 & 559 & 559 & 353 \\
\hline
\end{tabular}

For this analysis, considering that the watershed is located in the highlands where there are few anthropogenic withdrawals/inputs, the runoff and recharge are presented as one value. All the values were calculated in the previous section and they are shown in Table 3.1.

\section{Table 3.1 Water budget.}


Table 3.2 Water budget considering runoff at Pita Bocatoma Station

\begin{tabular}{|l|l|l|l|l|l|l|l|}
\hline \multicolumn{7}{c}{ PITA BOCATOMA } \\
YEAR & $\begin{array}{l}\text { P } \\
(\mathrm{mm} / \mathrm{yr})\end{array}$ & $\begin{array}{l}\text { Runoff } \\
(\mathrm{mm} / \mathrm{yr})\end{array}$ & $\%$ & $\begin{array}{l}\text { PET (2) } \\
(\mathrm{mm} / \mathrm{yr})\end{array}$ & $\%$ & \multicolumn{3}{c|}{$\begin{array}{l}\text { Difference } \\
(\mathrm{mm} / \mathrm{yr})\end{array}$} \\
\hline 2011 & 1716 & 715 & $42 \%$ & 542 & $32 \%$ & 459 & $27 \%$ \\
\hline 2012 & 1440 & 437 & $30 \%$ & 541 & $38 \%$ & 462 & $32 \%$ \\
\hline 2013 & 1336 & 304 & $23 \%$ & 554 & $41 \%$ & 478 & $36 \%$ \\
\hline 2014 & 1243 & 508 & $41 \%$ & 552 & $44 \%$ & 183 & $15 \%$ \\
\hline Mean & 1434 & 491 & $34 \%$ & 547 & $38 \%$ & 395 & $28 \%$ \\
\hline $2011-2014$ & 1434 & 435 & $32 \%$ & 547 & $38 \%$ & 451 & $32 \%$ \\
\hline
\end{tabular}

\subsection{Glacier meltwater contribution}

The departures from regular sea Surface temperatures in the equatorial Pacific Ocean generate warmer or cooler periods which can affect weather patterns around the world by influencing high and low pressure systems, winds, and precipitation. This phenomena is known as El Niño and La Niña, together called the El Niño Southern Oscillation (ENSO). This may bring much needed moisture to a region while causing extremes of higher or lower amounts of water in others.

The retreat of the glacier in Ecuador is a consequence of global warming, ENSO (During El Niño period there is a low precipitation in highlands) as well as the volcanic activity. Glaciers typically provide a constant source of meltwater to sustain river flows during dry periods, the significance of the glacier melting can be different during different seasons, as the temperatures rise and glacier cover melts, more water flows to the rivers and aquifers systems from glaciers.

According to Caceres (2005), 31\% of volume of the Cotopaxi Volcano glacier has retreated in 21 years (1996-2010) which corresponds to a reduction rate of approximately 1.5\% per year. Comparing only the portion of glacier that is present in the Pita watershed and using the same data used in Caceres (2005), the volume of the glacier retreat from 1996 to 2010 is $0.013 \mathrm{~km}^{3}$, which is considered to be part of the glacier meltwater contribution (Table 3.3). 


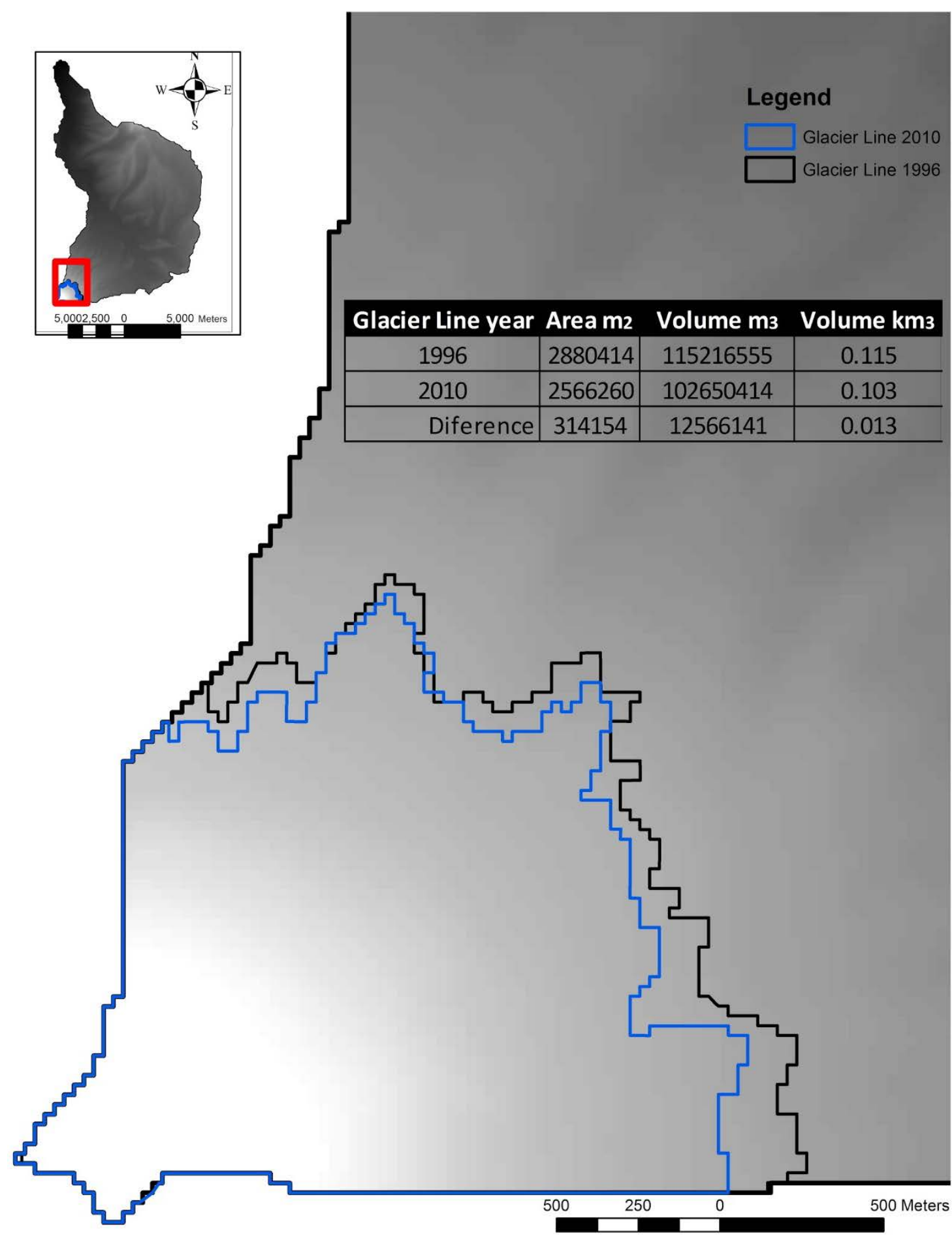

Figure 3.1 Reduction of the glacier in Cotopaxi Volcano in upper Pita Watershed (Source topographic base information EPMAPS, Glacier lines shapefiles from INAMHI-IRD-IG) 
Table 3.3 Glacier volume loss

\begin{tabular}{|l|l|l|l|}
\hline Glacier Line year & \multicolumn{1}{c}{ Area m } & \multicolumn{1}{c|}{ Volume m $^{\mathbf{3}}$} & Volume $\mathbf{k m}^{\mathbf{3}}$ \\
\hline 1996 & 2880413 & 115216555 & 0.115 \\
\hline 2010 & 2566260 & 102650414 & 0.103 \\
\hline Difference & 314153 & 12566141 & 0.013 \\
\hline
\end{tabular}

\subsection{Groundwater contribution}

\section{Hydrochemistry}

According to the surficial analysis that encompasses topography and hydrography, a reasonable hypothesis with respect to the water flow is that in some parts of the watershed there is a direct connection between glacier meltwater and some lakes and creeks. The connections mean that the volcanic terrains present at the higher part of the volcano are fractured and have a high permeability, which allows the glacial meltwater and precipitation infiltration to discharge down slope.

\section{Data}

To evaluate the chemical signature of the water, nine samples were taken from different sources, as described in Table 3.4. Two water samples are spring water, two from lakes and five from creeks. The geographic characteristics of the water samples are: both springs come out from fractured lavas, S-CH in the upper part and S-PAN in the lower part. L-SD is a natural lake that has subsurface inflow whereas L-SAL is a man-made lake that has surface inflow. C-MM, C-CM and C-YAN are creeks that come from Cotopaxi volcano hillslopes in the upper part. C-CH is a creek in the middle part and finally C-EC is a creek formed by Panzatilin spring. The location is shown in Figure 3.2.

Table 3.4 Water sample location with description of the type of source

\begin{tabular}{|l|l|l|l|r|l|}
\hline \multicolumn{1}{|c|}{ CODE } & \multicolumn{1}{c}{ NAME } & UTM X & UTM Y & ALTITUDE & COMMENTS \\
\hline S-CH & S. CHIRIMACHAY & 792201 & 9923525 & 3950 & Spring \\
\hline S-PAN & S. PANZATILIN & 785450 & 9941370 & 3546 & Spring \\
\hline L -SD & L. SANTO DOMINGO & 791784 & 9927304 & 4034 & Lake \\
\hline L-SAL & L. SALITRE & 787539 & 9935547 & 3717 & Man-made lake \\
\hline C-CM & C. CARNERO MACHAY & 788610 & 9931456 & 3897 & Creek \\
\hline C-YAN & C. YANGAHUAGRA & 791932 & 9926299 & 3945 & Creek \\
\hline C-MM & C. MAUCO MUDADERO & 791725 & 9926249 & 3960 & Creek \\
\hline C-CH & C. CHILCAHUAICO & 785820 & 9936095 & 3655 & Creek \\
\hline C-EC & C. EL CORTIJO & 784511 & 9941875 & 3480 & Creek \\
\hline
\end{tabular}




\section{Methodology}

On 31 July and 13 August 2014, water samples were collected according to procedures required by EPMAPS Control and Quality Lab (L3C). The sampling and analysis methods are certified by the Organismo de Acreditación Ecuatoriana (OAE) under ISO/IEC 17025: OAE LE 08-010. Also, all the water samples were analyzed at L3C for major ions and minor elements using atomic absorption spectrometry methodology. Results of the analysis are presented in Table 3.5.

Data interpretation was done using the following methods. Piper diagrams were used to analyze the main chemical composition of water based on the major anions and cations (Custodio and Llamas, 1983). The piper diagram was created using the Easy-Quim spreadsheet (Enric Vazquez, 1999). The ionic relationship ratios $\mathrm{rNa} / \mathrm{Cl}$; $\mathrm{rCl} / \mathrm{rHCO} 3$ and $\mathrm{rMg} / \mathrm{Ca}$ were used to identify the related aspects with the possible reactions that the water could pass through. Stiff diagrams were used to establish the spatial variation of the water composition, and Schoeller-Berkaloff diagrams were used to determine water-source mixing proportions. 


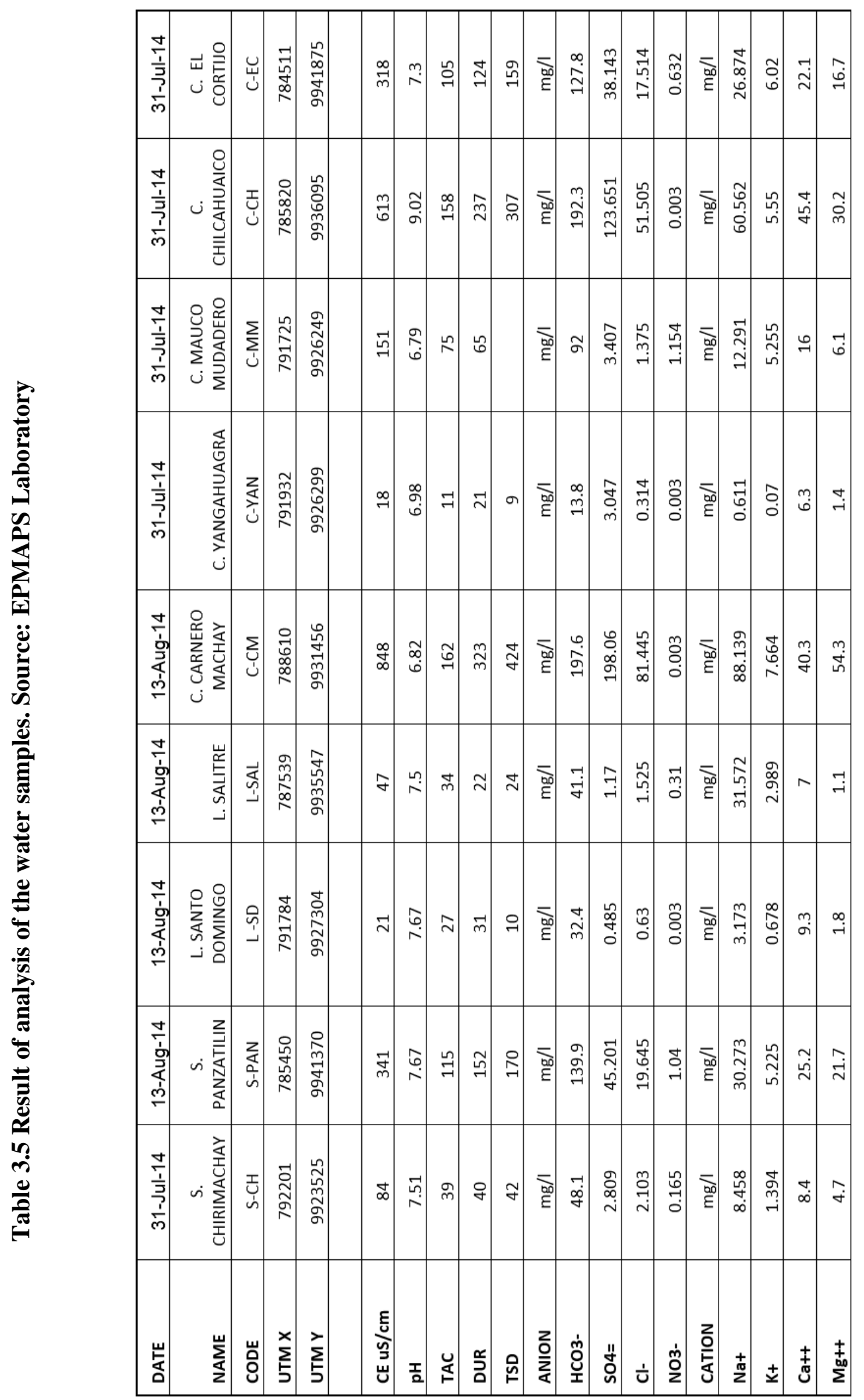




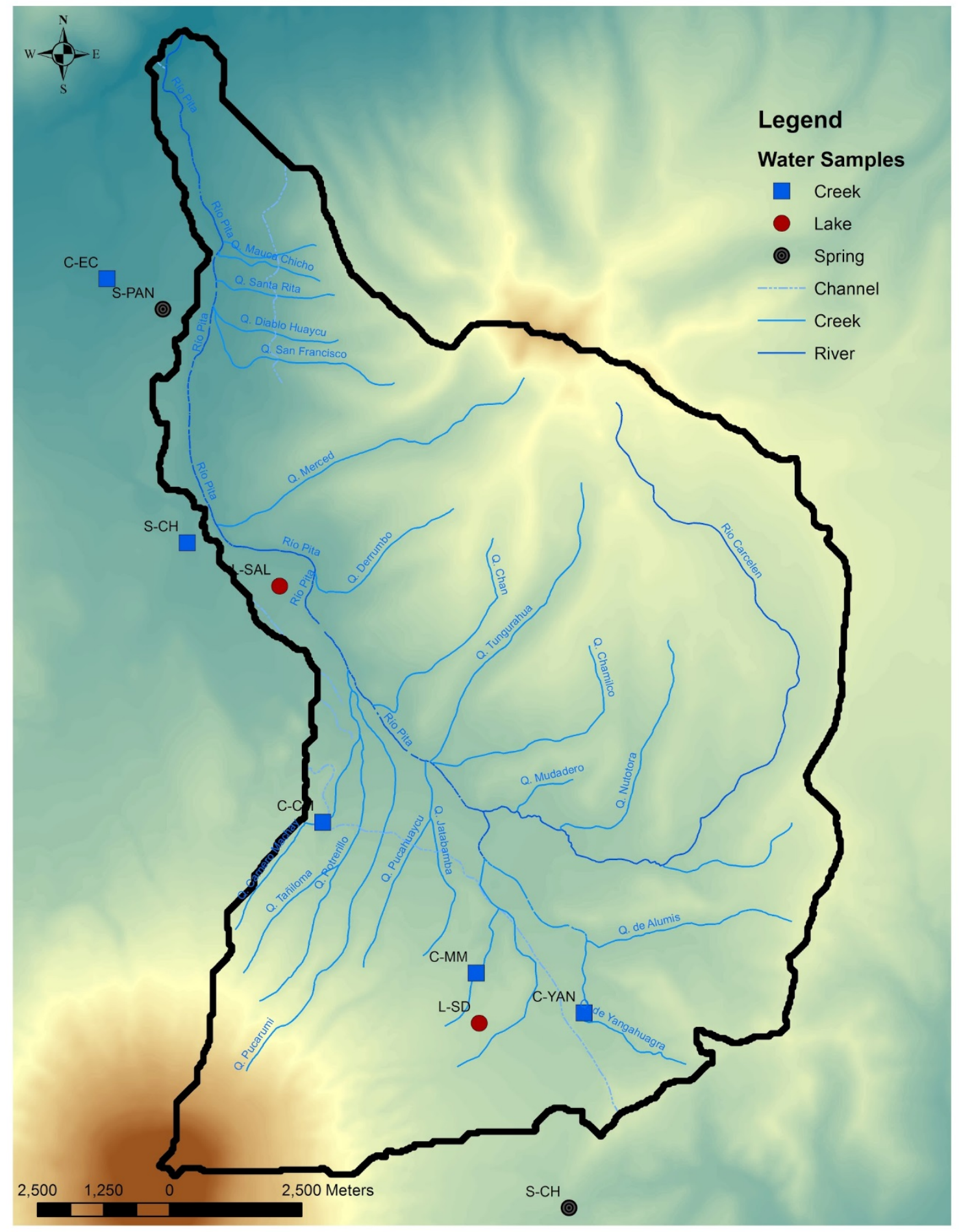

Figure 3.2 Location of the water samples in the study area (Map over DEM $30 \mathrm{~m}$ source EPMAPS) 
The Piper Diagram approach consists of two triangular species-proportion diagrams that lead to form one central rhomboid diagram that depicts the species combinations that can show mixing trends. One of the triangles represents the cation concentrations of $\mathrm{Ca}^{2+}$, $\mathrm{Mg}^{2+}$, and $\mathrm{Na}^{2+}$, whereas the other represents the anion concentrations $\mathrm{HCO}_{3}{ }^{-}, \mathrm{SO}_{4}{ }^{2-}$, and $\mathrm{Cl}^{-}$. Each triangle vertex represents $100 \%$ of one ion concentration in meq/L. One point into the triangle represents the percentage of each ion with respect to the other and after its projection to the central rhomboid (Figure 3.3) (Custodio and Llamas, 1983).

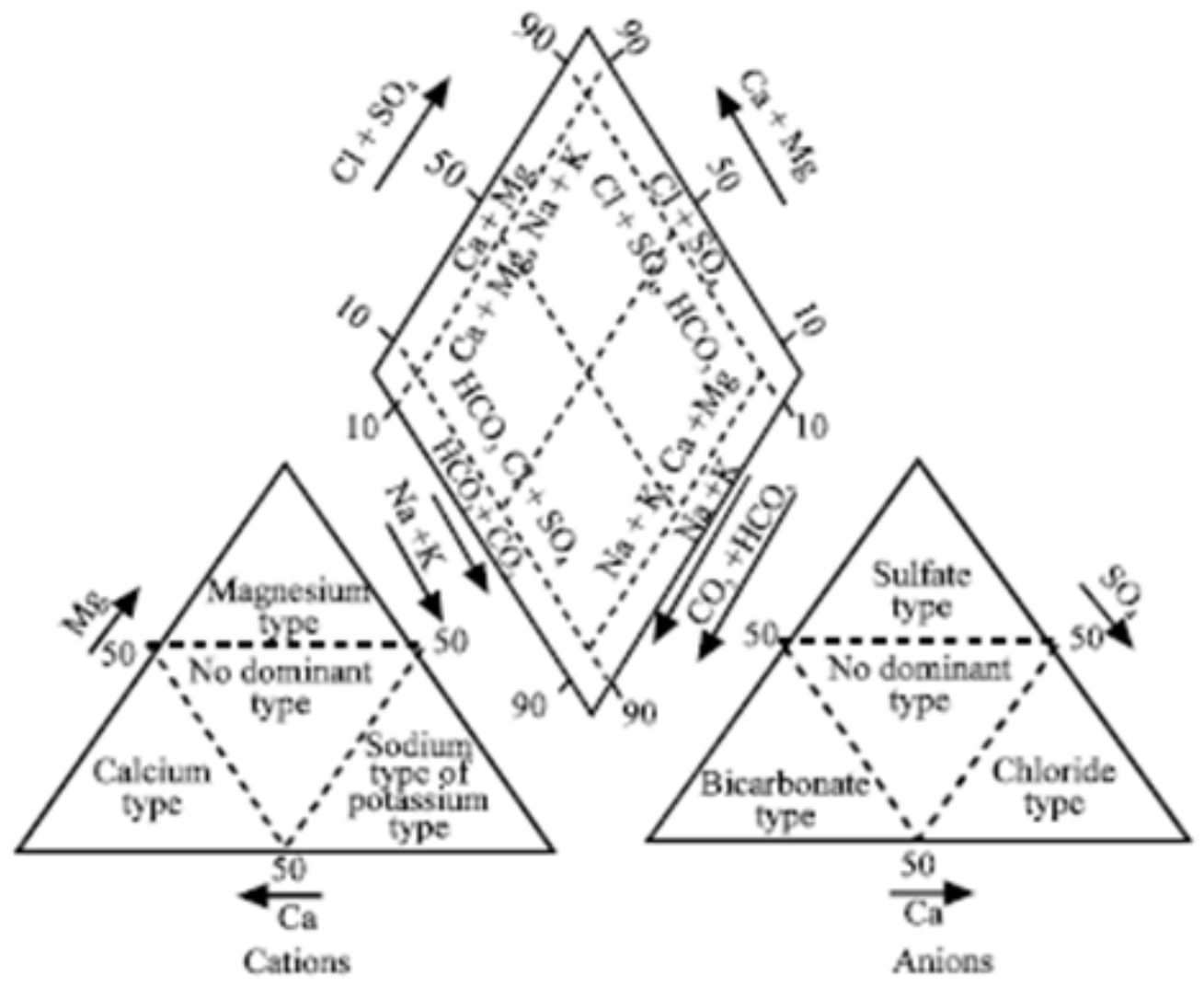

Figure 3.3 Piper diagram. Source: http://pr.water.usgs.gov/

The origin and ground-surface relationship was determined by the chemical relationship between ratios of several ions such as $\mathrm{Na}^{+}, \mathrm{Cl}^{-}, \mathrm{Mg}^{+2}$, and $\mathrm{HCO}_{3}{ }^{-}$. The ratio relationships serve to identify the possible reactions and processes such as dissolution, precipitation, and ionic interchange that water could have had in its interaction with the ground. This methodology consists of calculating ionic ratios in meq/L and comparing them with the known values for the same ratios of the water sources. The $\mathrm{rMg} / \mathrm{Ca}$ and $\mathrm{rCl} / \mathrm{rHCO}_{3}$ were used to establish the precipitation - dissolution of $\mathrm{CaCO}_{3}$ in some sections and infer possible water flow paths. Additionally, the $\mathrm{rNa} / \mathrm{Cl}$ was used to estimate the lithological contribution (Custodio and Llamas, 1983). 
Finally, the composition and distribution of the water in the study area were determined using Stiff diagrams, which are a graphical representation of the relative abundance of major cations and anions (Figure 3.4). The length of each horizontal line on a Stiff plot is proportional to the equivalent concentration each anion and cation (Appelo and Postma, 2005). The Stiff diagrams for the water samples are plotted onto the area map in their respective locations.

The GeoStif program, developed by Texas Water Development Board, was used for preparing the graphs. This is a program that produces georeferenced Stiff diagrams from an input file with the anion and cation concentrations in meq/L. It allows one to select the preferred output parameters and it gives a polygon shape file that can be displayed and edited in ArcGIS. After getting the output shape file, I edited the shape file in order to scale it for better visualization.

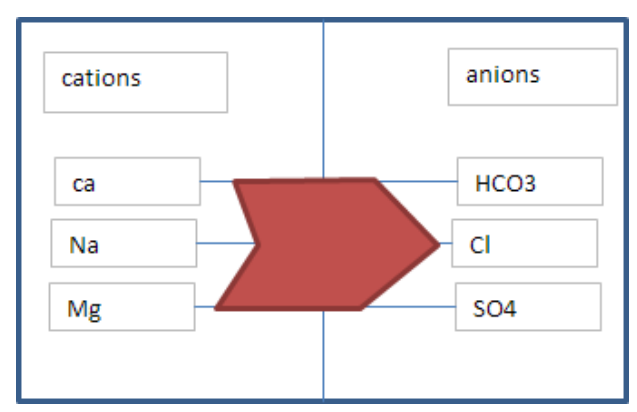

Figure 3.4 Stiff diagram

\section{Results}

Once the values were plotted in the Piper diagram (Figure 3.5), water samples were determined to be bicarbonate type based on the anion content, but C-CM and C-CH are bicarbonate-sulfate-chloride. Additionally, the cation content showed that water samples from the springs (S-CH, S-PAN) and from the creeks (C-MM, C-CM, C-CH, C-EC) are a mixture sodic-magnesic and magnesic-sodic types; however, water samples from C-YAN and L-SD are calcic and L-SALis sodic-potassic (Figure 3.5).

The mixture of magnesic-sodic and sodic-magnesic types can be interpreted as either surface or groundwater with little mineralization. The $\mathrm{Na}^{+}$and $\mathrm{Mg}^{2+}$ content suggests weathering of ferro-magnesium silicates, such as hypersthene, biotite, and/or olivine, which are common in the volcanic sedimentary rocks in the watershed (Hall and Mothes, 2008; De Miguel Fernandez, 2012).

C-YAN and L-SD are calcic type, due to ionic interchanges between $\mathrm{Ca}^{+}$and $\mathrm{Na}^{+}$that are contained in volcanic sedimentary deposits with plagioclase and amphibole (Hall and Mothes, 2008) in contact with water (De Miguel Fernandez, 2012). 
L-SAL is a man-made lake which receives water load with fine sediments from Cotopaxi uphill slopes. L-SAL is sodic-potassic type in which sodium is released from the weathering of feldspar minerals present in the rock, like plagioclase and augite- two minerals reported by Hall and Mothes (2008) in rocks present in the creek beds.
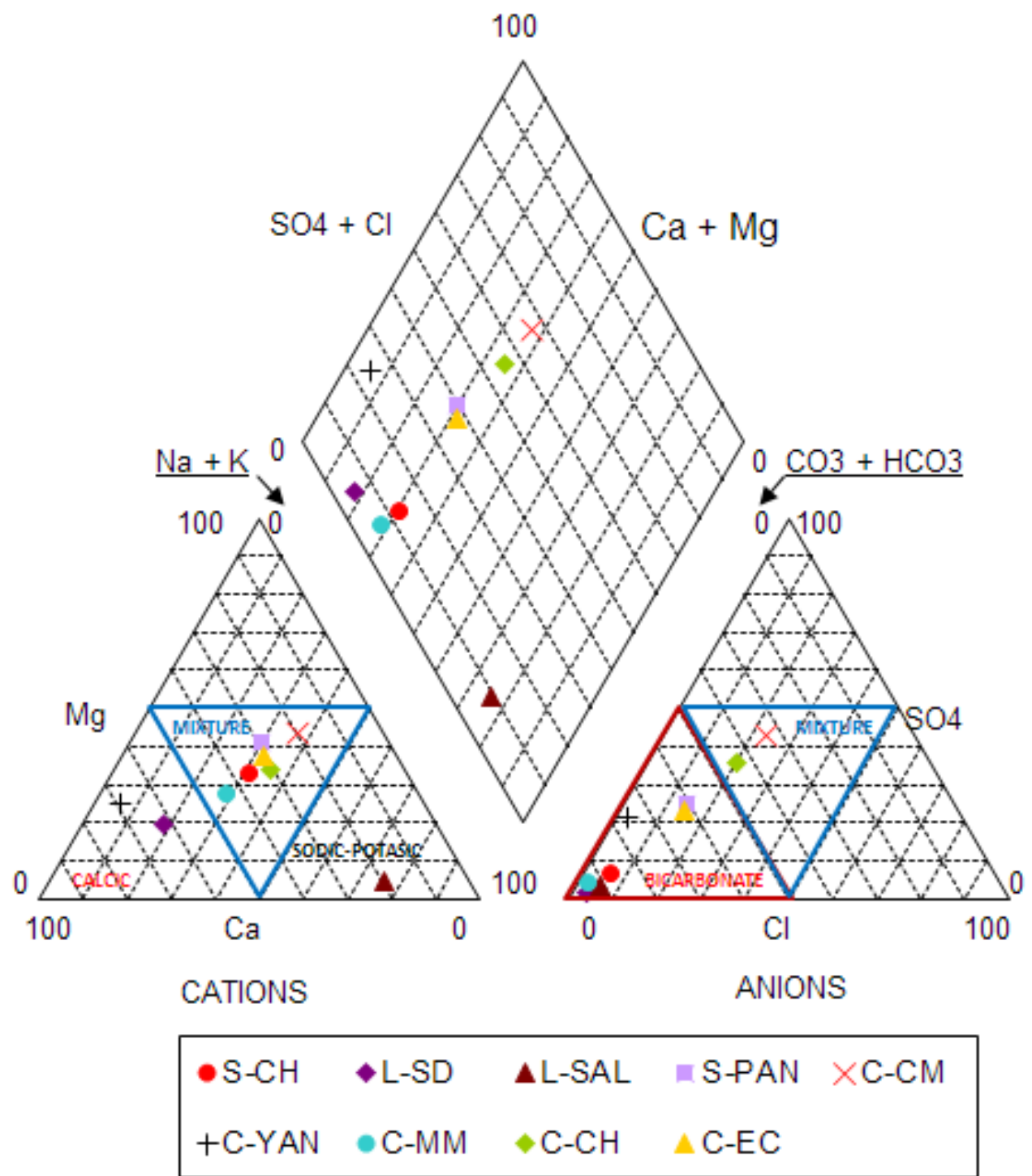

Figure 3.5 Water classification based on Piper Diagram (Spreadsheet developed by Enric Vàzquez Suñé, 1999 updated 2001)

The ratios analysis and a consideration of the south to north water path flow and that the ratios of $\mathrm{rMg} / \mathrm{rCa}$ and $\mathrm{rCl} / \mathrm{rHCO} 3$ decrease, (C-CM to L-SAL) it can be concluded that there is calcium carbonate dissolution (Appelo and Postma, 2005). From L-SAL to S-PAN the ratios of $\mathrm{rMg} / \mathrm{rCa}$ and $\mathrm{rCl} / \mathrm{rHCO} 3$ increase, which means there is precipitation of calcium carbonate, implying that it is concordant to infiltration processes (Appelo and 
Postma, 2005; Custodio and Llamas, 1983). Additionally, the ratio $\mathrm{rNa} / \mathrm{rCl}$ is variable throughout the watershed and indicates the lithological contribution, consisting of sediment loads in C-MM and L-SAL (See Table 3.6).

Table 3.6 Report of $\mathrm{rMg} / \mathrm{rCa}, \mathrm{rCl} / \mathrm{rHCO}$ and $\mathrm{rNa} / \mathrm{rCl}$ ratios calculations.

\begin{tabular}{|c|c|c|c|}
\hline Sample Code & $\mathbf{r M g} / \mathbf{r C a}$ & $\mathbf{r C l} / \mathbf{r H C O}$ & $\mathbf{r N a} / \mathbf{r C l}$ \\
\hline S-CH & 0.92 & 0.08 & 6.20 \\
\hline C-YAN & 0.37 & 0.04 & 3.00 \\
\hline L-SD & 0.32 & 0.03 & 7.77 \\
\hline C-MM & 0.63 & 0.03 & 13.79 \\
\hline C-CM & 2.22 & 0.71 & 1.67 \\
\hline L-SAL & 0.26 & 0.06 & 31.94 \\
\hline C-CH & 1.10 & 0.46 & 1.81 \\
\hline S-PAN & 1.42 & 0.24 & 2.38 \\
\hline C-EC & 1.24 & 0.24 & 2.37 \\
\hline
\end{tabular}

The Stiff diagrams show the distribution of the chemical composition of the water in the study area (Figure 3.7). This represents the degree of mineralization in the water. The increase in mineralization, especially $\mathrm{Na}^{+}$and $\mathrm{Mg}^{2+}$ ions, is observed along inferred general flow paths from uphill to downhill where the Panzatilin spring is located. It can be concluded that this is the result of cation exchange between the rock and the water.

Additionally, a chemical-mixing model for water was developed using the SchoellerBerkaloff diagrams, which displays anion and cation concentrations on a logarithmic scale to show the mixing of water from different origins. In this case, Figure 3.6 shows the corresponding Schoeller-Berkaloff diagram for surficial water (precipitation) and glacial melt water.

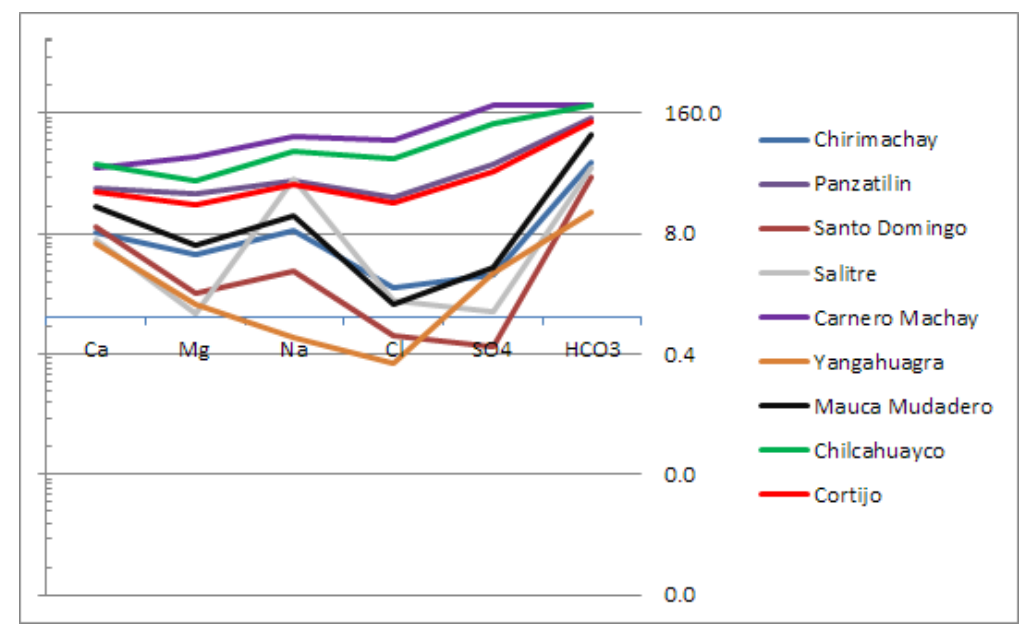

Figure 3.6 Chemical model using Schoeller-Berkaloff diagrams 


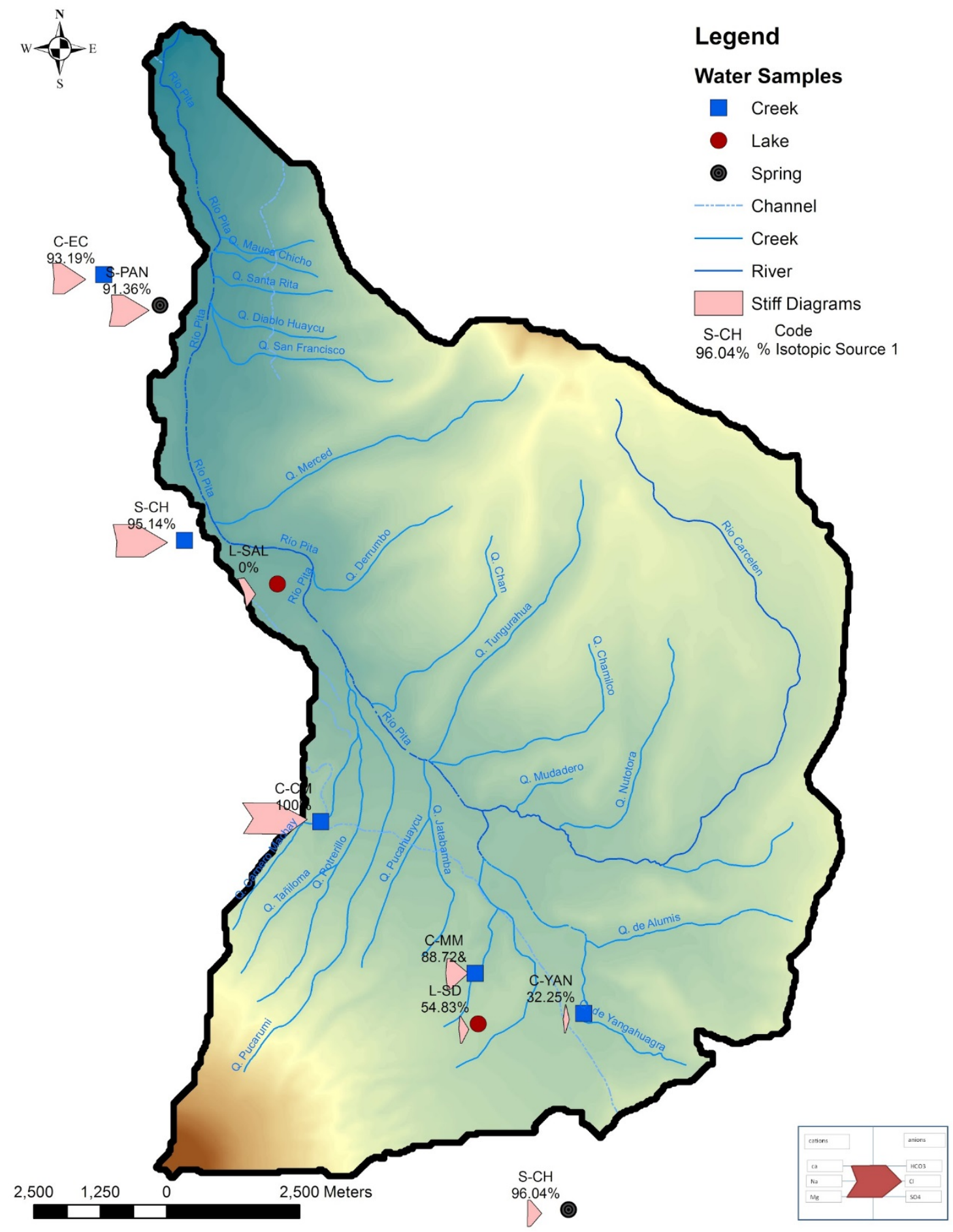

Figure 3.7 Stiff diagrams and isotopic fraction values at Upper Pita Watershed 


\section{Isotopic analysis}

Analysis of stable environmental isotopes of oxygen and hydrogen, oxygen-18 $\left({ }^{18} \mathrm{O}\right)$ and deuterium $\left({ }^{2} \mathrm{H}\right)$, respectively, was performed with samples from nine locations (Figure 3.9). Two of them were groundwater origin, two were surface water from small lakes and five come from different creeks. Samples for analysis were taken in July and August 2014. Lab analysis was carried out by Soil, Water, \& Climate laboratory in the University of Minnesota. The results are shown in Table 3.7.

An assumption was made in this topic while interpreting the results (Table 3.6). The El Salitre lake (L-SAL) presents $\delta^{2} \mathrm{H}$ values $-38.810 / 00$ and $\delta^{18} \mathrm{O}-4.47$ being the biggest isotopic signature and Carnero Machay creek (C-CM) presents $\delta 2 \mathrm{H}$ values -90.09 0/00 and $\delta^{18} \mathrm{O}-13.00$ being the lowest isotopic signature in the study area.

In the L-SAL case, as was mentioned before, it receives water from some creeks from Cotopaxi volcano hillslopes sediment loads; and C-CM is a creek that probably receives glacier meltwater from uphill.

Furthermore, after constructing the local meteoric water line (LMWL), Taupin in EPMAPS (2005), the comparison between $\delta^{18} \mathrm{O}$ and $\delta^{2} \mathrm{H}$ values and the deviations are not observed (Figure 3.9). This indicates that the mean isotopic composition of water samples is similar to recent precipitation. Additionally, it can be assumed that the altitude effect in the deflection of the $\delta^{18} \mathrm{O}$ is independent of the seasons (Grootes et al., 1989).

Table 3.7 Results of oxygen-18 and deuterium from water samples.

\begin{tabular}{|c|c|c|c|c|c|c|c|}
\hline Code & Date & Type & Name & $\delta^{2} \mathbf{H}$ & $\delta^{2} H$ stdv & $\delta^{18} \mathrm{O}$ & $\delta^{18} \mathrm{O}$ stdv \\
\hline L-SAL & $11 / 08 / 2014$ & Surface Water & EL SALITRE & $-38,81$ & 0,38 & $-4,47$ & 0,09 \\
\hline C-YAN & $11 / 07 / 2014$ & Surface Water & YANGAHUAGRA & $-55,35$ & 1,08 & $-8,05$ & 0,20 \\
\hline L-SD & $11 / 08 / 2014$ & Surface Water & SANTO DOMINGO & $-66,93$ & 0,24 & $-8,93$ & 0,07 \\
\hline C-MM & $11 / 07 / 2014$ & Surface Water & MAUCO MUDADERO & $-84,30$ & 0,21 & $-12,11$ & 0,15 \\
\hline S-PAN & $11 / 08 / 2014$ & Groundwater & PANZATILIN & $-85,66$ & 1,33 & $-12,02$ & 0,17 \\
\hline C-EC & $11 / 07 / 2014$ & Surface Water & EL CORTIJO & $-86,60$ & 0,46 & $-11,68$ & 0,23 \\
\hline $\mathrm{C}-\mathrm{CH}$ & $11 / 07 / 2014$ & Surface Water & CHILCAHUAICO & $-87,60$ & 0,53 & $-12,17$ & 0,14 \\
\hline $\mathrm{S}-\mathrm{CH}$ & $11 / 08 / 2014$ & Groundwater & CHIRIMACHAY & $-88,06$ & 0,29 & $-13,01$ & 0,29 \\
\hline $\mathrm{C}-\mathrm{CM}$ & $11 / 07 / 2014$ & Surface Water & CARNERO MACHAY & $-90,09$ & 0,76 & $-13,00$ & 0,19 \\
\hline
\end{tabular}




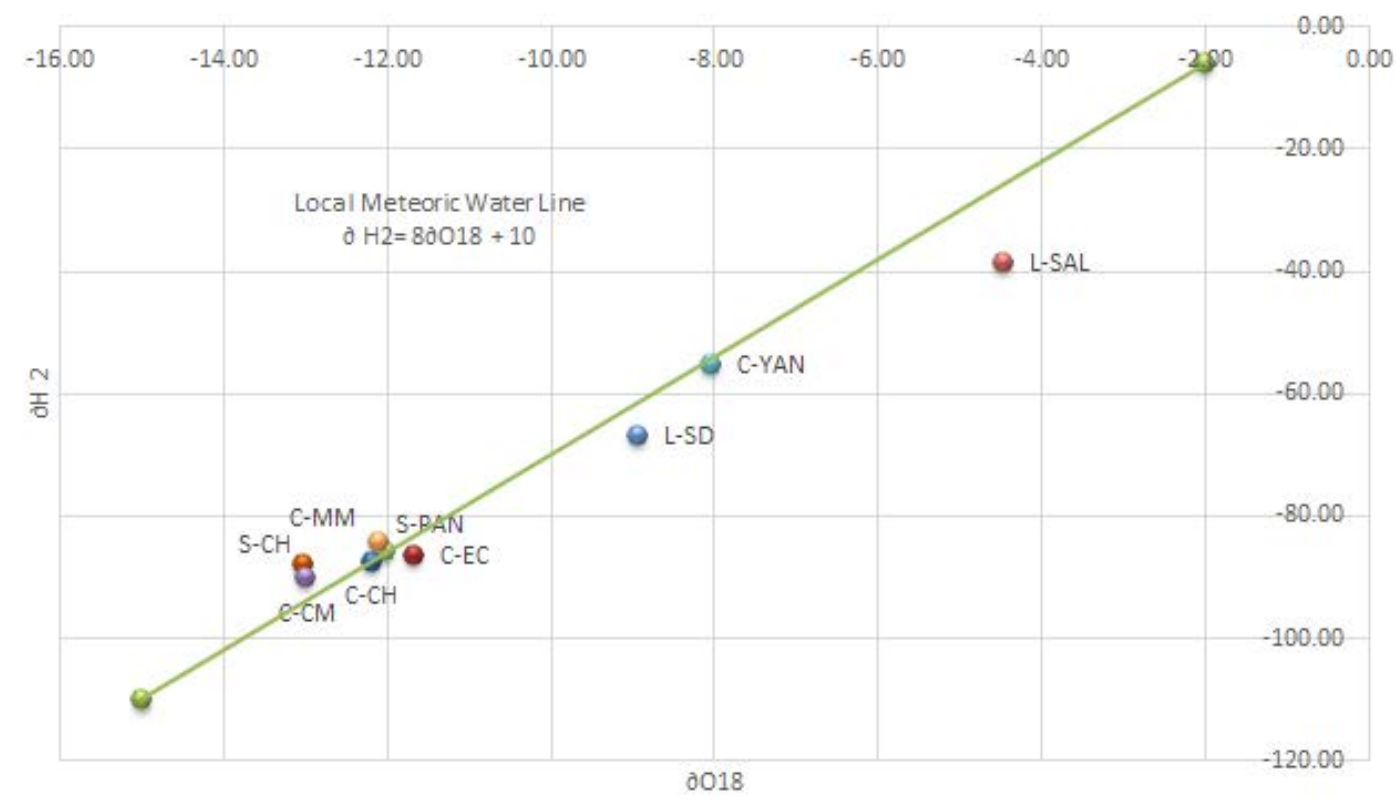

Figure 3.9 Stable isotope distributions of oxygen-18 and deuterium from water samples. All of the samples analyzed plot along the Local Meteoric Water Line. 


\section{SECTION IV CONCLUSIONS AND RECOMMENDATIONS}

\subsection{Conclusions}

Using geospatial, meteorological, hydrogeological, and geochemical data to understand the relationship between the glacier meltwater and surface water and groundwater flowing into and under the Pita River, it can be concluded that:

\section{Meteorological analysis}

- The climate of the study area is cold. According to Pourrut et al. (1995), the climate corresponds to equatorial cold high mountain climate. The annual average temperature is $8.41^{\circ} \mathrm{C}$, whereas the annual average rainfall is $1320 \mathrm{~mm}$ and the evapotranspiration is around $38-43 \%$ of the precipitation value. Hydrological conditions generated, an average, water yields in the basin of $17.9 \mathrm{l} / \mathrm{s} / \mathrm{km}^{2}$.

- Precipitation and temperature show a topographic control. The amount of precipitation is more abundant in the lower part than the higher part. However, the temperature is lower in the higher part than the lower part, and it has little variation through time.

\section{Land Use}

- The presence of the paramo vegetation in the watershed (65\% of the area) has a sustained contribution to the flow basis, which results in the high water regulation capacity of it. Meanwhile the pastures area (20\%) represents a risk in terms of water regulation capacity because livestock are exposing soils to erosion.

\section{Geology and hydrogeology}

- $\quad$ EPMAPS described the aquifer system as an unconfined aquifer. The lava flows were considered to be the basemen;t however, the lava deposits are not present in all areas, and they have secondary porosity, so they should not be considered as basement rock.

- Data analysis show ionic interchanges between infiltrating water and the minerals that are contained in volcanic sedimentary deposits.

\section{Catchment areas}

- According to the relationship between area and discharge, discharge for the Pita watershed $\left(3.1 \mathrm{~m}^{3} / \mathrm{s}\right)$ corresponds with the areas of the watershed $\left(173 \mathrm{~km}^{2}\right)$. Cotopaxi volcano's contribution is 33\%, so 1021 l/s come from it. 


\section{Glacier contribution}

- The volume of the glacier retreat from 1996 to 2010 is $0.013 \mathrm{~km}^{3}$, which is considered to be glacier meltwater contribution.

\section{Chemistry and Isotopic analysis}

- All the samples demonstrate a mixture signature between the two possible endmember sources; therefore, if my assumption that the water discharged at CMM creek sample site is infiltrated glacial meltwater, it can be concluded that there is infiltrated glacial meltwater present in the middle and lower parts of the watershed. This should be examined further in the future.

- Excluding lake samples, the $\delta^{18} \mathrm{O}$ and $\delta^{2} \mathrm{H}$ values show only minor deviations to the local meteoric water line (LMWL). This indicates that the mean isotopic composition of water samples is similar to recent precipitation.

\subsection{Recommendations}

- The contributions of the glacier melting water will ascertain in the context of current climatic and geological conditions. Creating a hydrogeological model to estimate how the contributions of the glacier melting water might change as a result of future climate changes and the impacts of these changes on water supplies in this region would be useful for planning purposes.

It is necessary to have at least one year of isotopic data of rain and snow samples in order to obtain better results in the chemical modeling.

- It is necessary to have hydrogeological data from monitoring wells to establish the variability of the water level.

- It is recommended to analyze the coefficient of variability of the springs. 


\section{References}

Appelo, C.A.J. and Postma, D. 2005. Geochemistry,Groundwater and Pollution, Sec. Ed., Leiden, The Netherlands. Balkema Publishers.

ASCE, Evapotranspiration and Irrigation Water Requirements, Jensen, M.E., R.D. Burman, and R.G. Allen (editors), ASCE Manuals and Reports on Engineering Practice No. 70, 1990.

Burbano, N., Becerra, S. and Pasquel E., Introducción a la Hidrogeología del Ecuador, 2011, INAMHI-Ecuador.

Buytaert, W., Célleri, R., De Bièvre, B., Cisneros, F., Wyseure, G., Deckers, J., Hofstede, R. 2006. Human impact on the hydrology of the Andean páramos. Earth-Science Reviews 79 (2006) 53-72.

Cáceres, B., Ramírez, J., Francou, B., Eissen, J., Taupin, J., Jordan, E., Ungerecchts, L., Maisincho, L., Barba, D., Cadier, E., Bucher, R., Peñafiel, A., Samaniego, P., Mothes, P., 2004. Determinación del Volumen del Casquete de Hielo del Volcán Cotopaxi. Informe INAMHI-IRD-IG-EPN-INGEOMINAS.

CLIRSEN, 2006, Diagnostico Ambiental de la Cuenca del Rio Pita

Custodio, E. y Llamas, M.R. 1983. Hidrologia Subterranea. Editorial Omega. Volumen I y III. Barcelona.

De Bièvre, B., Iñiguez, V., Buytaert W., Cisneros, F. Hidrología del páramo: Importancia, propiedades y vulnerabilidad, Retrieved from http://paramo.cc.ic.ac.uk/pubs/ ES/Hidroparamo2.pdf.

De Miguel Fernandez, C. 2012. Hidrogeología Aplicada con Aspectos Ambientales. Edum. Cuba

Empresa Pública Metropolitana de Agua Potable y Saneamiento, EPMAPS. 2014. Technical Reports.

Gierke, J., 2012, Monthly Water Budgets. Michigan Technological University. Department of Geological and Mining Engineering and Sciences.

Grootes, P. and Stuiver, M. 1989. Oxygen isotope changes in tropical ice, Quelccaya, Peru. Journal of Geophysical Research, Vol 94, \# D1, Pages 1187-1194. 
Hall M.L. and Mothes P. 2007. Rhyolitic calderas and centers clustered within the active andesitic belt of Ecuador's eastern cordillera. Instituto Geofísico, Escuela Politécnica Nacional. Earth and Environmental Science 3 (2008) 012007.

Harden, C. P.: Human impacts on headwater fluvial systems in the Northern and Central Andes, Geomorphology, 2006.

Instituto Nacional de Estadísticas y Censos. INEN, Censo Población y Vivienda. 2010. Retrieved from: http://www.ecuadorencifras.gob.ec.

IPCC, 2014: Climate Change 2014: Synthesis Report. Contribution of Working Groups I, II and III to the Fifth Assessment Report of the Intergovernmental Panel on Climate Change [Core Writing Team, R.K. Pachauri and L.A. Meyer (eds.)]. IPCC, Geneva, Switzerland, $151 \mathrm{pp}$.

Jordan, E., Ungerechts, L., Caceres, B. Penafiel, A., Francou, B. 2005. Estimation by photogrammetry of the glacier recession on the Cotopaxi Volcano (Ecuador) between 1956 and 1997. Hydrological Sciences-Journal-des Sciences Hydrologiques, 50(6) December 2005.

Mena Vásconez, Patricio and Robert Hofstede, 'los Páramos Ecuatorianos", en Mónica Moraes, et al., edits., Botánica Económica de los Andes Centrales, La Paz, Universidad Mayor de los Andes, 2006.

Mileti, Dennis S.; Bolton, Patricia A.; Fernandez, Gabriel; Updike, Randall G. (1991). The Eruption of Nevado Del Ruiz Volcano Colombia, South America, November 13, 1985. Washington, D.C.: Commission on Engineering and Technical Systems (National Academy Press). p. 13.ISBN 0-309-04477-4.

Molano, C. 2.011. Piper Hydrogeochemical Diagram. Retrieved from https://sites.google com/a/hidrogeocol.com.co/carlos_molano/home.

Mothes P., Hall M.L., Samaniego P., Andrade D. \& Yepes H., 2004 - Mapa Regional de los peligros potenciales del volcán Cotopaxi - Zona Sur. Ech. 1/50.000. Edit. IGMIG/EPN-IRD-Embajada de Alemania en Quito.

PETROECUADOR,-MAG, Actualización mapa hidrogeológico y de cuencas Hidrográficas del ecuador escala 1:1’000000 con referencia a la infraestructura del sector Hidrocarburĺfero (edición provisional), 2005, Quito -Ecuador.

Pourrut et. al. (1995). Los Climas del Ecuador- Fundamentos Explicativos. Estudio realizado en el marco de un convenio entre la ORSTOM y PRONAREG (Programa 
Nacional de Regionalización Agraria del Ministerio de Agricultura y Ganadería). Quito, Julio de 1983.

Texas Water Development Board. Geostiff program. Retrieved from http://www.twdb. state.tx.us/publications/reports/GroundWaterReports/Open-File/Open-File_01001.htm.

Tucci, C.E.M., 2009 Plan de Manejo Integrado de los Recursos Hídricos en la Cuenca Alta del Río Guayllabamba. BID Banco Interamericano de Desarrollo Económico y FONAG Fondo para la Protección del Agua. 147p.

UNESCO. 2009. Climate Change Impacts: Glacial Melt, Past, Present and Future. Bolivia. Information Forum Bulletin Special Edition: Focus on Climate Change.

USGS. 2014. Lahars and Their Effects. Retrieved from http://volcanoes.usgs.gov/ hazards/lahar.

Verduga, L. Zak, V. and Guevara, M., 2008. Mapa de ecosistemas y uso del suelo en el área de influencia del FONAG. TNC-FONAG, Ecuador. 